GA-A15602

UC-77

\title{
ANALYSIS OF EXPERIMENTS IN THE PHASE III GCFR BENCHMARK CRITICAL ASSEMBLY
}

by

A. L. HESS and K. J. BAYLOR

\author{
Prepared under \\ Contract DE-AT03-76SF71023 \\ for the San Francisco Operations Office \\ Department of Energy
}

DATE PUBLISHED: APRIL 1980

\section{GENERAL ATOMIC COMPANY}




\section{DISCLAIMER}

This report was prepared as an account of work sponsored by an agency of the United States Government. Neither the United States Government nor any agency Thereof, nor any of their employees, makes any warranty, express or implied, or assumes any legal liability or responsibility for the accuracy, completeness, or usefulness of any information, apparatus, product, or process disclosed, or represents that its use would not infringe privately owned rights. Reference herein to any specific commercial product, process, or service by trade name, trademark, manufacturer, or otherwise does not necessarily constitute or imply its endorsement, recommendation, or favoring by the United States Government or any agency thereof. The views and opinions of authors expressed herein do not necessarily state or reflect those of the United States Government or any agency thereof. 


\section{DISCLAIMER}

Portions of this document may be illegible in electronic image products. Images are produced from the best available original document. 
This report was prepared as an account of work sponsored by an agency of the United States Government. Neither the United States nor any agency thereof, nor any of their employees, makes any warranty, expressed or implied, or assumes any legal liability or responsibility for any third party's use or the results of such use of any information, apparatus, product or process disclosed in this report, or represents that its use by such third party would not infringe privately owned rights.

Printed in the United States of America Available from

National Technical Information Service

U.S. Department of Commerce

5285 Port Royal Road

Springfield, VA 22161

NTIS price codes

Printed copy: A06

Microfiche copy: A01 
GA-A15602

UC-77

\title{
ANALYSIS OF EXPERIMENTS IN THE PHASE III GCFR BENCHMARK CRITICAL ASSEMBLY
}

\author{
by \\ A. L. HESS and K. J. BAYLOR
}

\begin{abstract}
Prepared under
Contract DE-AT03-76SF1023 for the San Francisco Operations Office Department of Energy
\end{abstract}

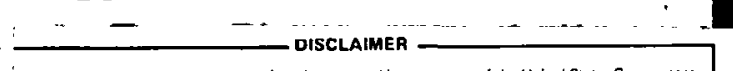

his book was prepared as an account of work sponsored by an ogency of the United States Government. teither the United States Government nor any agency thereof, nor any of their employees. makes ony Ompleteness. of usefuiness of any information, apparatus, producl, or process disclosed, or cepresents that its uso woutd not inflringe privertely owned rights. Reterence hesein to any specitic

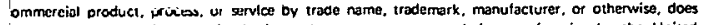
iot necessarily constitute or imply its encorsement, recommendation, or fovering or the United iacessatily state of reflect those of the United States Government or any agency thereot.

GENERAL ATOMIC PROJECT 6113 DATE PUBLISHED: APRIL 1980

\section{GENERAL ATOMIC COMPANY}


THIS PAGE

\section{WAS INTENTIONALLY \\ LEFT BLANK}




\section{ABSTRACT}

Experiments carried out in the third gas-cooled fast breeder reactor (GCFR) benchmark critical assembly on the Zero Power Reactor-9 at Argonne National Laboratory were analyzed using methods and computer codes employed routinely for design and performance evaluations on power-plant GCFR cores. The program for the Phase III GCFR assembly, with a 1900-liter, threeenrichment zone core, included measurements of reaction-rate profiles in a typical power-flattened design, studies of material reactivity coefficients, reaction ratio and breeding parameter determinations, and comparison of pin with plate fuel loadings. Calculated parameters to compare with all of the measured results were obtained using 10-group cross sections based on ENDF/B-4 and two-dimensional diffusion theory, with adjustments for fuelcell heterogeneity and void-lattice streaming effects. In general, the analytical predictions agree well with measurements, except for centra1worth discrepancies and U-238-capture/Pu-239-fission ratios, where calculational biases of $10 \%$ to $20 \%$ are observed, typical of analyses on 1iquid meta1 fast breeder reactor critical assemblies. Additional study on streaming. effects is 1ndicated. The report includes extensive details on the analytical models and procedures. 
THIS PAGE

\section{WAS INTENTIONALLY \\ LEFT BLANK}




\section{CONTENTS}

ABSTRACT . . . . . . . . . . . . . . . . . . . . . 1 . . 1 . .

1. INTRODUCTION . . . . . . . . . . . . . . . . . . 1-1

2. DESCRIPTION OF THE PHASE III ASSEMBLY . . . . . . . . . . 2-1

2.1. Assembly Details . . . . . . . . . . . . 2-1

2.2. Experimental Assembly Reactivity Determinations . . . 2-6

3. ANALYTICAL MTHEODS ................... . . . 3-1

3.1. Processing of ENDF/B-4 Basic Nuclear Data . . . . . 3-1

3.2. Generation of Broad Group Cross Sections ....... . 3-3

3.3. Heterogeneity Adjustments . . . . . . . . . 3-6

3.4. Neutron Streaming Effects ............. 3-8

3.5. Diffusion Theory Calculations . . . . . . . . 3-13

3.6. Perturbation Theory Calculations . . . . . . . . 3-13

4. CRITICALITY CALCULATIONS ................ . . 4-1

4.1. Reference Configuration, Cylindrical Geometry . . . . 4-1

4.2. Reference Configuration, XY Geometry . . . . . . . . 4-1

4.3. Core-Edge Fuel Worth ................. 4-4

4.4. Pin-Zone Reactivity Worth ............ . 4-4

5. SMALL SAMPLE REACTIVITY COEFFICIENTS . . . . . . . . . . 5-1

5.1. Central Worth Calculations . . . . . . . . . 5-1

5.2. Comparisons With Measured Central Worths ...... . 5-3

5.3. Macerial-Worth Radial Yrotiles........... 5-5

5.4. Apparent-Worth Profile For Cf-252 Neutron Source. . . 5-13

5.5. Calculational Biases For Material Worths . . . . . . 5-13

6. REACTION RATE RATIOS . . . . . . . . . . . . . 6-1

6.1. Foil Activations For Fuel Reactions . . . . . . . . 6-1

6.1.1. U-235/Pu-239 Fission Ratio......... 6-7

6.1.2. U-238/Pu-239 Fission Ratio......... . 6-7

6.1.3. U-238 Capture/Pu-239 Fission Ratio . . . . . 6-7

6.1.4. U-238/U-235 Fission Ratio . . . . . . . . 6-8

6.1.5. U-238 Capture/U-235 Fission Ratio . . . . 6-8 
6.2. Dilute-Sample Fission Ratios . . . . . . . . . 6-9

6.3. Dilute-Sample Capture Ratios . . . . . . . . . . 6-11

6.4. Absolute Reaction Rates ............. 6-12

7. REACTION RATE PROFILES . . . . . . . . . . . . . . 7-1

7.1. Radial Reaction-Rate Distributions . . . . . . . . 7-1

7.2. Axial Reaction Rate Distributions . . . . . . . . 7-7

7.3. Power Profile Calculations . . . . . . . . . . . 7-8

7.4. Reaction Rate Scans Through Radial Traverse Tube . . . 7-14

8. CENTRAL CONVERSION RATIO EXPERIMENT . . . . . . . . . . . 8-1

8.1. Absorption-to-Fission Ratios . . . . . . . . . . 8-1

8.2. Central Conversion Ratio... . . . . . . . . . 8-4

9. PIN ZONE SUBSTITUTION EXPERIMENT . . . . . . . . . . . . 9-1

9:1. Pin Zone Specifications . . . . . . . . . . . 9-1

9.2. Pin Zone Substitution Worth Components . . . . . . . . 9-1

9.3. Axial Fission-Rate Profile In Pin Zone . . . . . . . . 9-7

9.4. Foil Activations For Reaction Ratios In Fuel Pins . . . 9-7

10. SUMMARY . . . . . . . . . . . . . . . . . 10-1

REFERENCES . . . . . . . . . . . . . . . . . . . 11-1

APPENDIX . . . . . . . . . . . . . . . . . . . . A-1

\section{FIGURES}

2-1. Quadrant view at midplane of reference configuration for the Phase III GCFR critical assembly . . . . . . . . . 2-2

2-2. Typical plate-cell and pin-cell loadings used in regions of the Phase III GCFR critical assembly . . . . . . . . . 2-5

3-1. General Atomic cross section generation for fast reactors . . 3-2

3-2. Adjustments of cross sections for cell heterogeneity and streaming . . . . . . . . . . . . . . . . . 3-7

5-1. Radial worth traverse for Pu-239 . . . . . . . . . . 5-6

5-2. Radial worth traverse for enriched uranium. . . . . . . . 5-7

5-3. Radial worth traverse for depleted uranium . . . . . . . 5-8

5-4. Radial worth traverse for stainless steel . . . . . . . 5-9

5-5. Radial worth traverse for B-10 . . . . . . . . . . 5-10

5-6. Radial worth traverse for Li-6 . . . . . . . . . . 5-11

5-7. Radial worth traverse for $\mathrm{CH}_{2}$ foam . . . . . . . . 5-12 
5-8. Radial worth traverse for Cf-252 source........ . 5-14

7-1. Pu-239 radial fission rate profile . . . . . . . . . 7-2

7-2. U-235 radial fission rate profile........... . 7-3

7-3. U-238 radial fission rate profile... . . . . . . . . . 7-4

7-4. U-238 radial fission rate profile, logarithmic scale . . . 7-5

7-5. U-238 radial capture rate profile . . . . . . . . . 7-6

7-6. Pu-239 axial fission rate distribution . . . . . . . . 7-9

7-7. U-235 axial fission rate distribution . . . . . . . . 7-10

7-8. U-238 axial fission rate distribution . . . . . . . . . 7-11

7-9. U-238 axial fission rate distribution, logarithmic scale . 7-12

7-10. U-238 axial capture rate distribution . . . . . . . . . 7-13

7-11. Phase III radial power profiles at $1 \mathrm{~kW}$. . . . . . . . 7-15

7-12. Pu-239 fission rate scan in radial traverse tube . . . . . 7-17

7-13. Li-6 radial capture rate profile . . . . . . . . . . 7-18

9-1. Core configuration for GCFR Phase III pin zone assembly . . . 9-2

9-2. Pu-239 axial fission rate profile in pin zone . . . . . . 9-8

\section{TABLES}

2-1. Basic specifications of Phase III critical assembly representation of GCFR . . . . . . . . . . . . . . 2-3

2-2. Sumnary of experimental reactivity evaluations for reference configurations of Phase III GCFR critical assembly .. . . . . . . . . . . . . . . . . 2-7

3-1. Neutron cross section group structure and comparisons of calculated core center spectra . . . . . . . . . . 3-5

3-2. Comparison of heterógeneity correction factors derived for cross sections used in Phase III calculations . . . . . . . 3-9

3-3. Arisotropic diffusion coefficient modifiers for Phase III analysis . . . . . . . . . . . . . . . . 3-11

3-4. Calculated delayed neutron parameters for reference Phase III GCFR critical assembly . . . . . . . . . . . . 3-14

4-1. Eigenvalues calculated using two-dimensional diffusion theory for reference loadings of Phase III GCFR critical assembly • 4-2

4-2. Comparison of measured versus calculated eigenvalues for Phase III GCFR assembly and assessment of analytical bias . . 4-3

5-1. Comparison of ANL and GA central worth calculations for Phase III GCFR critical assembly . . . . . . . . . 5-2 
5-2. Comparisons of measured and calculated worths of material samples at center of Phase III core... . . . . . . . . .

5-3. Radial worth traverse for Pu-239 sample at midplane of Phase III assembly . . . . . . . . . . . . . . 5-15

5-4. Radial worth traverse for depleted uranium sample at midplane of Phase III GCFR assembly . . . . . . . . . 5-16

5-5. Radial worth traverse for steel sample at midplane of Phase III GCFR assembly. . . . . . . . . . . . . 5-17

5-6. Radial worth traverse for B-10 sample at midplane of Phase III GCFR assembly . . . . . . . . . . . . . 5-18

6-1. Measured and calculated cell average per-atom ratios of U-235 fission to Pu-239 fission in Phase III GCFR assembly . 6-2

6-2. Measured and calculated cell average per-atom ratios of U-238 fission to $\mathrm{Pu}-239$ fission in Phase III GCFR assembly • 6-3

6-3. Measured and calculated cell average per-atom ratios of U-238 capture to Pu-239 fission in Phase III GCFR assembly . 6-4

6-4. Measured and calculated cell average per-atom ratios of U-238 fission to U-235 fission in Phase III GCFR assembly . . 6-5

6-5. Measured and calculated cell average per-atom ratios of U-238 capture to U-235 fission in Phase III GCFR assembly . - 6-6

6-6. Comparison of measured and calculated spectral indices at center of Phase III core . . . . . . . . . . . . . 6-10

6-7. Calculated reaction rates for dilute-sample isotopes at center of Phase III core . . . . . . . . . . . . 6-13

8-1. Absorption-to-fission $(1+\bar{\alpha})$ ratios for dilute fuel isotopes in core of Phase III GCFR critical assembly . . . 8-3

8-2. Component reactions for central conversion ratio evaluation - 8-5

8-3. Evaluation of point conversion ratio at center of core in Phase III GCFR critical assembly . . . . . . . . . . 8-6

9-1. Summary of eigenvalue calculations using two-dimensional diffusion theory for pin zone configuration in Phase III GCFR assembly ...... . . . . . . . . . . . . 9-4

9-2. Components of reactivity effect for exchange of pin fuel for plate fuel in a central zone of Phase III assembly : . . 9-5

9-3. Comparison of cell average fuel reaction ratios measured in pin-loaded assembly with calculated ratios ........ 


\section{INTRODUCTION}

The program for the development of a demonstration plant for a gas-cooled fast breeder reactor (GCFR), includes plans (Ref. 1) for several stages of critical experiments to validate GCFR core physics design methods. The initial stage of these GCFR simulation studies, carried out on the Zero Power Reactor-9 (ZPR-9) machine at Argonne National Laboratory (ANL) and completed in 1976, was a series of three simple assemblies, with only clean core/blanket geometries, to study basic GCFR physics characteristics. This first stage has been designated the benchmark series of GCFR critical experiments. Future progressions of GCFR critical experiments include those of the pre-engineering mockup critical (pre-EMC) series through to the engineering mockup, which will attempt to closely model the detailed final demonstration plant core design.

In the benchmark series of experiments, the first assembly, Phase-I (Ref. 2), was a demonstration size (for a 300-MW(e) plant) system with a 4100-1iter core of a single enrichment (17.1\%). Except for the uniform cost and overall geometric simplicity, the Phase-I assembly closely matched the reference plant design in core size and average enrichment, with a $55 \%$ volume fraction for coolant (void space used in these mockups). The Phase I study proved valuable as a first-of-a-kind, large GCFR-like fast-neutron assembly, showing no problems in the analytical interpretation using methods previously validated predominantly by analyses of sodium-cooled fast critical studies.

The Phase I1 GCFR benchmark critical assembly (Ref. 3) was a 1300liter-core condensed version of the Phase I system achieved by reducing the void (coolant) volume fraction to $45 \%$. The basic emphasis of the Phase II experimental program was an extensive study of simulated steam entry (Ref. 4) into the coolant channels and the effects of such on basic physics characteristics. Analysis at General Atomic Company (GA) of these studies 
(Ref. 5) has contributed significantly to the development of better physics methods and to understanding of the GCFR core characteristics.

This report concerns the last of the GCFR benchmark studies, the Phase III GCFR critical assembly. In Phase III, the core contained three radial enrichment zones with a total volume of 1912 liters. The basic objective was to evaluate the ability of the methods to predict power distributions in a typically zoned GCFR core. Another study with the Phase III system involved replacement of the usual ZPR plate drawer loadings in a central core zone with a pin loading more like that of the power reactor core. The measured effects due to the pin/plate exchange provide tests of comparable rod-fueled designs and aid in reducing the uncertainties in interpolation of the critical assembly results to the real GCFR design.

Full details on the design of and the experimental results from the Phase III study have been reported by Morman (Ref.6), along with the results of the ANL post-analysis of the Phase III work. The reference core analytical models used in the GA calculations were adopted directly from the ANL Phase III report. In many ways, the basic analytical procedure used at GA is similar to that of the ANL analysis, exccpt that at ANL a 28-group cross section structure was adopted, whereas at GA the analysis utilized 10-group cross sections as has been standard for the design and performance calculations for the GCFR. The sections that follow contain a brief description of the Phase III assembly and a review of the GA methods for analysis. Results of GA calculations are then compared with the measurements in several categories. Also, some comparisons of the GA analytical results with ANL calculated data are made to assess the limitations of using the broader group structure. Finally, attempts are made to quantify the calculational biases inherent in the GA analytical methods combined with the basic cross section data used [ENDF/B-4 (Ref. 7)] . 


\section{DESCRIPTION OF THE PHASE III ASSEMBLY}

\subsection{ASSEMBLY DETAILS}

The ZPR-9 at Argonne, Illinois, is one of the split-table criticalassembly machines in the U.S. and abroad employed for studying the physics characteristics of fast neutron reactor systems. The halves of the reactor, on the fixed and movable tables, consist of square arrays of steel matrix tubes ( 45 tubes by 45 tubes), each of which is $5.52 \mathrm{~cm}(2.17 \mathrm{in.}$ ) square and $122 \mathrm{~cm}$ (48.03 in.) long. Steel trays or drawers, loaded with longitudinal columns of fuel, fertile, and diluent plates, are installed in the matrix tubes in prescribed arrays to provide the core, blanket, and reflector regions for the fast reactor configuration under study. Although operated at low power ( $1 \mathrm{~kW}$ or less), measurements on an assembly provide physics parameters, such as critical size, power profiles, reaction rate profiles, reactivity coefficients, and neutron spectral indices representative of similar design power reactors.

Figure 2-1 is a view at the interface (between halves) of one quadrant of the Phase III GCFR assembly, showing the radial outlines of the core zones, the radial blanket, and the reflector; the other three quadrants were symmetrically arranged in the reference critical loading. (For simplicity, the positions of the normally withdrawn ZPR operational control rods are not shown.) The core is radially zoned similarly to the expected core design in the GCFR demonstration plant, given the limitations inherent in the ZPR fuel inventory on mocking up specific enrichments. For the Phase III system, the enrichments (percent fissile plutunfum in heavy metal) of $13.1 \%, 17.3 \%$, and $25.5 \%$, respectively, for core zones 1,2 , and 3 were selected based on pre-analysis predictions of radial power flattening combinations.

Table 2-1 summarizes the basic geometric details and makeup of the Phase III assembly and indicates, as a representation of a GCFR, the 


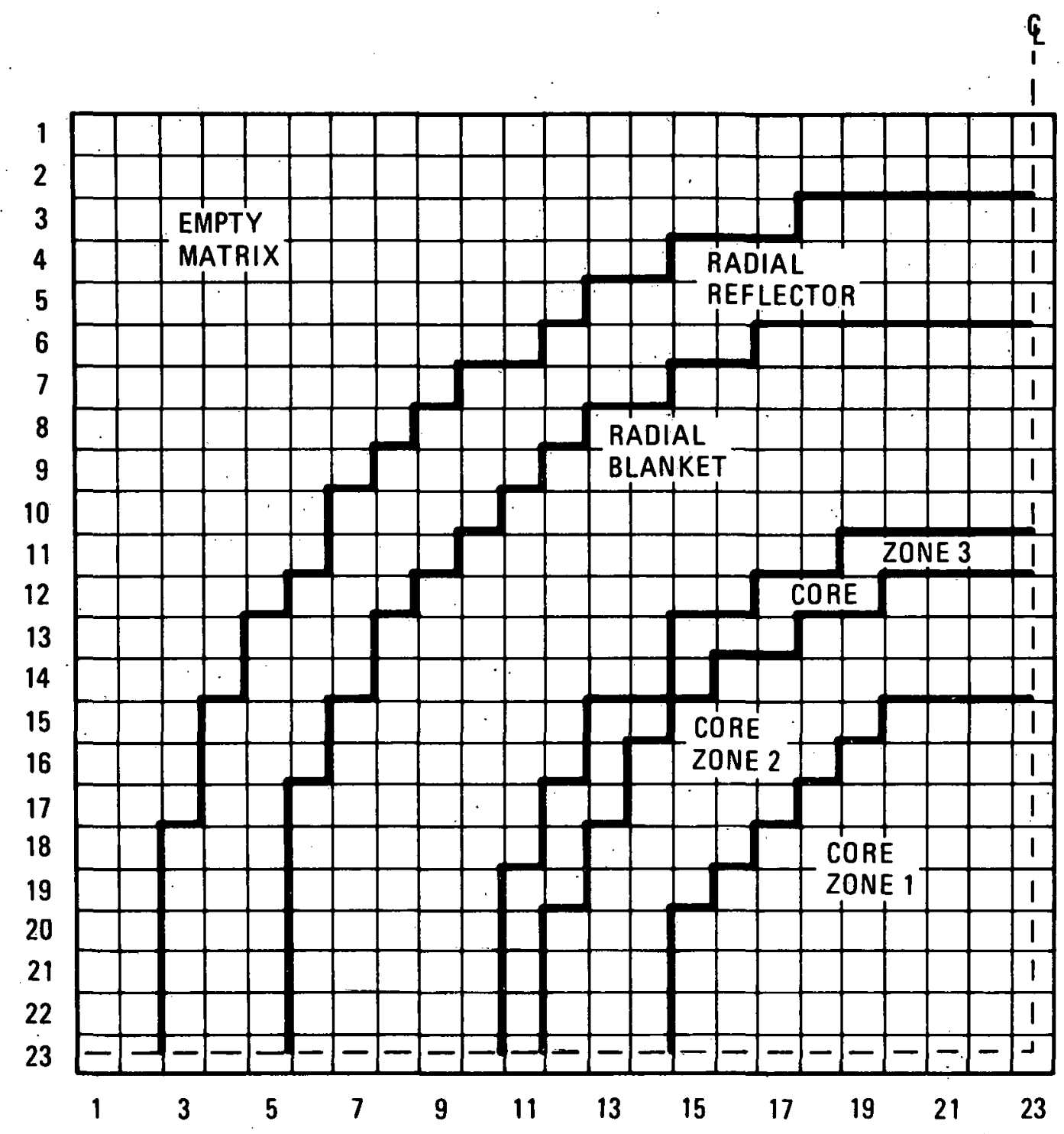

Fig. 2-1. Quadrant view at midplane of reference configuration for the Phase III GCFR critical assembly 
TABLE 2-1

BASIC SPECIFICATIONS OF. PHASE III CRITICAL ASSEMELY REPRESENTATION OF GCFR

\begin{tabular}{|c|c|c|c|c|c|c|c|}
\hline $\begin{array}{l}\text { Reactor } \\
\text { Region }\end{array}$ & $\begin{array}{c}\text { Core } \\
\text { Zone } 1\end{array}$ & $\begin{array}{c}\text { Core } \\
\text { Zone } 2\end{array}$ & $\begin{array}{c}\text { Core } \\
\text { Zone } 3\end{array}$ & $\begin{array}{l}\text { Axial } \\
\text { Blankets }\end{array}$ & $\begin{array}{l}\text { Radial } \\
\text { Blanket }\end{array}$ & $\begin{array}{c}\text { Axial } \\
\text { Refectors }\end{array}$ & $\begin{array}{c}\text { Radial } \\
\text { ReÉlectors }\end{array}$ \\
\hline Drawers per half & $2 \approx 9$ & 192 & 92 & 513 & 508 & 513 & $332^{-}$ \\
\hline Regior: length, cm & 122.08 & 122.08 & 122.08 & 30.48 ea & 183.04 & 15.49 ea & 183.04 \\
\hline Outer radius, $\mathrm{cm}$ & 47.17 & 63.95 & 719.60 & 70.60 & 99.59 & 70.60 & 114.65 \\
\hline $\begin{array}{l}\text { Effective volume } \\
\text { fractions }\end{array}$ & & & & . & & & \\
\hline Fuel or fertile $(a)$ & 30.7 & 31.1 & 31.6 & 37.3 & 42.1 & -- & -- \\
\hline Steel & 20.5 & 23.5 & $2 \varepsilon .5$ & 14.4 & 14.4 & 88.4 & 92.3 \\
\hline Coolant (void) & 48.8 & 45.4 & 39.9 & 48.3 & 43.5 & 11.6 & 7.7 \\
\hline Heavg netal mass, kg & 2309.8 & 1959.4 & 955.1 & 3096.5 & 10406.1 & -- & -- \\
\hline $\begin{array}{c}\text { Fissile enrichment, } \\
\text { at. } \%\end{array}$ & 13.1 & 17.3 & 25.5 & Depleted U & Depleted U & -- & -- \\
\hline Calculated p̧ower data & & & & & & & 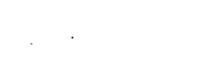 \\
\hline $\begin{array}{l}\text { Region power } \\
\text { fraction }\end{array}$ & $0 . \angle 25$ & 0.3454 & 0.1775 & 0.0135 & 0.0382 & -- & -- \\
\hline $\begin{array}{l}\text { Region peak/average } \\
\text { power density }\end{array}$ & 1.417 & 1.435 & 1.367 & 3.065 & 4.628 & -- & -- \\
\hline $\begin{array}{l}\text { Region Feak/core } \\
\text { density }\end{array}$ & 1.424 & 1.396 & $1 . \dot{4} 93$ & 0.087 & 0.126 & -- & -- \\
\hline
\end{tabular}

(a) Mixed-oxide fuel ( $\mathrm{Pu} \mathrm{J}_{2}-\mathrm{UO}_{2}$ ) or uranium oxide simulated by combinations of Pu-U-Mo alloy plates, $\mathrm{Fe}_{2} \mathrm{O}_{3}$ plates, and $\mathrm{U}_{3} \mathrm{O}_{7}^{2}$ plates. 
regional power splits. In terms of size, the 1900-liter total core volume would be typical of a power reactor of about a 130-MW(e) rating, based on current assessments of a maximum GCFR fuel rod power rating. As specified by Fig. 2-1 and Table 2-1, the Phase III reference configuration contained $888 \mathrm{~kg}$ fissile plutonium ( $\mathrm{Pu}-239+\mathrm{Pu}-241)$ and had an available excess reactivity of 215 inhours ( $\mathrm{Ih}$ ) (about $\$ 0.66$ ), based on the measured worths of partially inserted $Z P R-9$ control rods at criticality. The clean justcritical mass (all rods withdrawn) would have been $880 \mathrm{~kg}$ fissile plutonium.

Typical loadings of the drawers installed in the various regions of the assembly are shown by front views in Fig. 2-2. For the core zone 1 plate loading [Fig. 2-2(a)], the combination of two $0.635-\mathrm{cm}(0.25-\mathrm{in}$.) thick columns of $\mathrm{U}_{3} \mathrm{O}_{8}$ with a column of plutonium-sandwich $[\mathrm{a} 0.635-\mathrm{cm}(0.25-\mathrm{in})$. $\mathrm{Pu}-\mathrm{U}-\mathrm{Mo}$ alloy plate between $0.3175-\mathrm{cm}(0.125-\mathrm{in}$.$) thick \mathrm{Fe}_{2} \mathrm{O}_{3}$ plates] provided the simulation of $13 \%$ enriched mixed oxide fuel $\left(\mathrm{PuO}_{2}-\mathrm{UO}_{2}\right)$. For core zone 2, the unit cell loading (not shown) consisted of three drawers containing a distribution of four columns each of the $\mathrm{U}_{3} \mathrm{O}_{8}$ and the plutonium sandwich; this was the core cell used in the uniform-core-enrichment Phase II assembly to represent $17 \%$ enriched $\mathrm{PuO}_{2}-\mathrm{UO}_{2}$. For core zone 3, the $25.5 \%$ enrichment was attained with a single drawer cell containing two columns only of the plutonium sandwich. For all three core zone cells, the coolant channels, simulated with void cans of $0.635-\mathrm{cm}(0.25-\mathrm{in}$.$) and 1.25-\mathrm{cm}$ (0.5-in.) widths, summed to an average of $2.54-\mathrm{cm}$ (1-in.) width per drawer to yield a total void fraction (including other gaps) of $\sim 45 \%$.

Figure 2-2(c) indicates the material loading in the core zone 1 drawers beyond the $60.96-\mathrm{cm}(24-\mathrm{in.})$ core half height to represent the axial blanket region; it shows how the coolant channels are continuations of the core region voids and the fuel materials are replaced by fertile plates only (depleted uranium and $\mathrm{U}_{3} \mathrm{O}_{8}$ ). A similar loading scheme was utilized for the zones 2 and 3 axial blankets, maintaining the void channel continuity from the core and providing a relatively uniform composition axial blanket with 


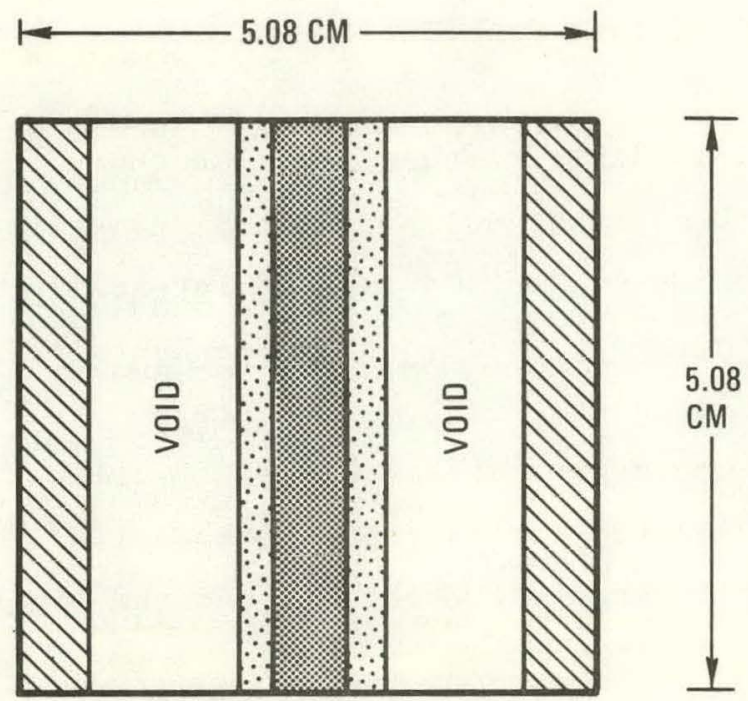

(a) ZONE 1 CORE DRAWER

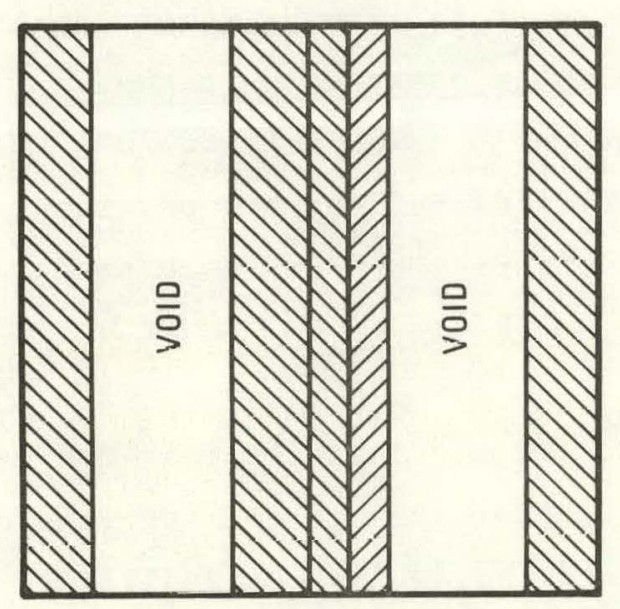

(c) ZONE 1 AXIAL BLANKET DRAWER

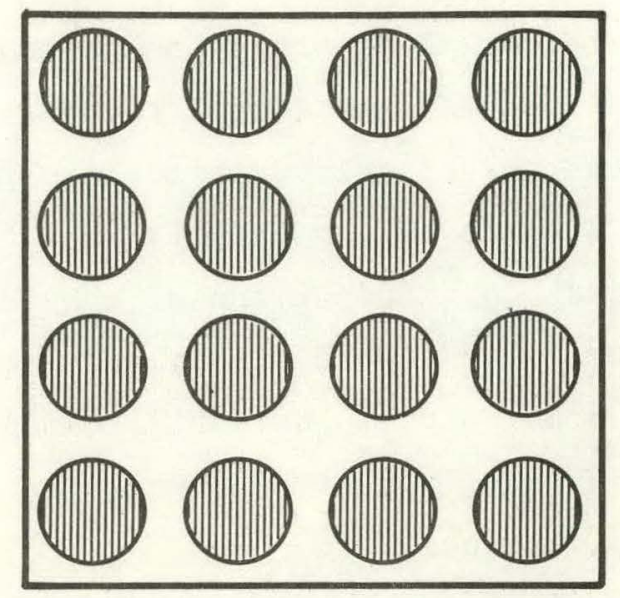

(b) ZONE 1 CORE CALANDRIA

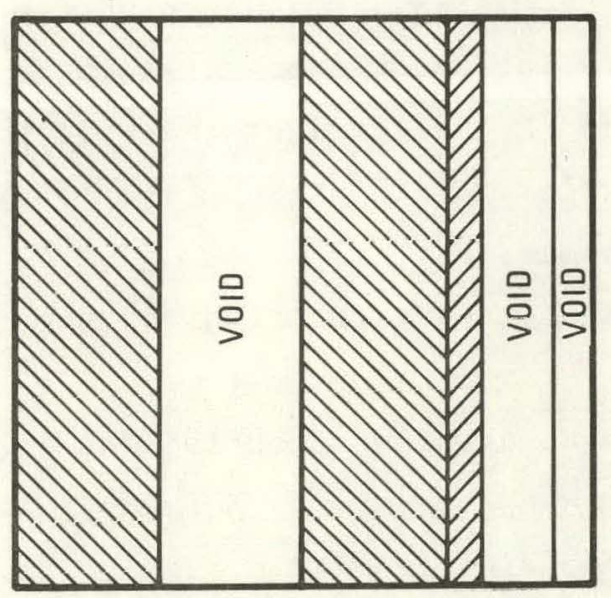

(d) RADIAL BLANKET DRAWER

LEGEND
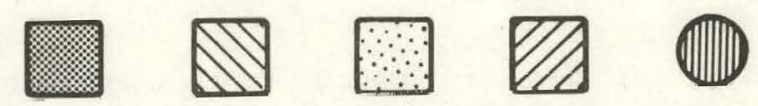

$\mathrm{Pu} \cdot \mathrm{U} \cdot \mathrm{Mo}_{0}$

Fig. 2-2. Typical plate-cell and pin-cell loadings used in regions of the Phase III GCFR critical assemh1yr 
45 vol \% void. For the radial blanket, the fertile material concentration was larger at the expense of a reduced coolant fraction (40\%).

Figure 2-2(b) shows the calandria loading for the center of the core zone 1 used as a match for the Fig. 2-2(a) plate cell. The fuel pins loaded into the voided calandria tubes were composed of $\mathrm{PuO}_{2}$ and $\mathrm{UO}_{2}$ integrally mixed at a $13.1 \%$ enrichment; in the pin zone blanket, the tubes contained depleted $\mathrm{UO}_{2}$. Comparison of the cells in Figs. 2-2(a) and 2-2(b) illustrates the more highly heterogeneous nature of the ZPR plate cells than the typical GCFR subassembly, considering the partial split of fissile/ fertile materials, the larger mean chord length of the fuel, and the bigger coolant channels.

The reflector regions surrounding the blankets of the assembly were constructed from solid blocks of type 304 stainless steel, loaded directly into the matrix axially behind the core drawers or filling 91.44-cm (36-in.) drawers for the radial reflector. Thus, the neutron streaming paths provided by the coolant channels terminatc at the blanket/reflector boundaries. Within each core zone, the repetitious cell arrays provide continuous vertical slabs of void, but the boundaries between core zones present some interruptions of these streaming paths.

More detailed descriptions of the drawer and regional loadings can be found in the report by Morman (Ref.6). The region average compositions and corresponding geometric models, as used in both the ANL and GA analyses, have been included in the Appendix.

\subsection{EXPERIMENTAL ASSEMBLY REACTIVITY DETERMINATIONS}

The experimental report identifies several assembly configuration variations for which the criticality status is listed, including repeats of the reference configuration defined above. Table 2-2 1ists the configurations pertinent to the analysis carried out here, including the core loadings, the run dates, and the measured available reactivity. The 
TABLE $2-2$

SUMMARY OF EXPERIMENTAL REACTIVITY EVALUATIONS FOR REFERENCE CONFIGURATIONS OF PHASE III GCFR CRITICAL ASSEMBLY

\begin{tabular}{|c|c|c|c|c|c|c|}
\hline \multirow[b]{2}{*}{ Configuration } & \multirow[b]{2}{*}{$\begin{array}{l}\text { Loading } \\
\text { Date }\end{array}$} & \multirow{2}{*}{$\begin{array}{l}\text { Core } \\
\text { Drawers } \\
\text { per } \\
\text { Half }\end{array}$} & \multirow{2}{*}{$\begin{array}{c}\text { Fissile } \mathrm{Pu} \\
\text { Loading as } \\
\text { of Loading } \\
\text { Date } \\
(\mathrm{kg} \pm 0.2)\end{array}$} & \multirow{2}{*}{$\begin{array}{l}\text { Measured } \\
\text { Available } \\
\text { Excess Re- } \\
\text { activity, } \\
\text { (Ih) }\end{array}$} & \multicolumn{2}{|c|}{$\begin{array}{c}\text { Reactivity Adjusted for } \\
\text { Decay of } \mathrm{Pu}-241 \text { since } \\
7 / 1 / 75(\mathrm{a})\end{array}$} \\
\hline & & & & & Ih & $\begin{array}{l}\text { Equivalent } \\
\mathrm{k}_{\mathrm{k}}(\mathrm{b})\end{array}$ \\
\hline $\begin{array}{l}\text { 1. Reference } \\
\text { critical }\end{array}$ & $7 / 1 / 76$ & 513 & 888.05 & $214.5 \pm 1.7$ & $258.3 \pm 4.7$ & $\begin{array}{r}1.00277 \pm \\
0.00005\end{array}$ \\
\hline $\begin{array}{l}\text { 2. Edge worth } \\
\text { study }\end{array}$ & $7 / 8 / 76$ & 509 & 877.43 & $-81.0 \pm 1.4$ & $-36.4 \pm 4.7$ & $\begin{array}{r}0.99961 \pm \\
0.00005\end{array}$ \\
\hline $\begin{array}{l}\text { 3. } \begin{array}{l}\text { Repeat } \\
\text { reference }\end{array}\end{array}$ & $8 / 18 / 76$ & 513 & 887.98 & $193.1 \pm 2.2$ & $242.8 \pm 5.4$ & $\begin{array}{r}1.00261 \pm \\
0.00005\end{array}$ \\
\hline $\begin{array}{l}\text { 4. Pin-zone } \\
\text { reference (de- } \\
\text { duced using } \\
\text { edge worth) }\end{array}$ & $8 / 27 / 76$ & 511 & 882.66 & $+44.3 \pm 2.5$ & $95.1 \pm 5.6$ & $\begin{array}{r}1.00102 \pm \\
0.00006\end{array}$ \\
\hline 5. Pin-zone loaded & $8 / 28 / 76$ & 511 & 882.57 & $+12.6 \pm 1.2$ & $63.5 \pm 5.2$ & $\begin{array}{r}1.00068 \pm \\
0.00006\end{array}$ \\
\hline
\end{tabular}

(a) Correction of -0.12 It/day adopted from ANL analysis $( \pm 10 \%)$.

(b) Conversion factor of $33.9 \mathrm{Ih} / \% \mathrm{k}$ adopted from GA analysis. 
table also gives reactivity values adjusted by the worth of the decay of Pu-241 from July 1, 1975, to the run dates listed; this correction was required to properly correlate the measurements with the analysis wherein the ANL specified compositions involve a plutonium-isotopic makeup evaluated as of July 1,1975 . The correction factor, $-0.12 \mathrm{Ih} /$ day, was based on ANL calculations. An equally acceptable correlation could have been achieved by adjusting the compositions for the decay of Pu-241 into Am-241 as of each run date, but this would be more tedious.

Configuration 2 in Table 2-2 was created by removing four core zone 3 drawers per half and replacing them with radial blanket drawers in an experiment to evaluate the core edge fuel reactivity coefficient. In reference to the quadrant view in Fig. 2-1, the exchanged drawer was in matrix location $12 / 17$ (row/column), and the other seven drawers were the symmetrical locations in the other quadrants in both halves. The measured total reactivity change of 295 Ih equals $36.9 \pm 0.3 \mathrm{Ih} / \mathrm{drawer}$ or $27.9 \mathrm{Ih} / \mathrm{kg}$ fissile plutonium content.

In the configurations 4 and 5 in Table 2-2, there were two less core drawers per half than the reference Phase III loading in the locations 12/17 and $34 / 17$. The differences in reactivity between these final cases express the effect of the exchanges of pin fuel for plate fuel in a central core region; this experiment will be examined in detail in Section 9. 


\section{ANALYTICAL METHODS}

The analyses of these benchmark series GCFR critical assembly experiments have been carried out with a procedure which parallels the methods employed for GCFR core design, but with additional precautions due to the more heterogeneous nature of the plate assembly loadings. This process involves the derivation of region appropriate cross sections from the basic cross section library [ENDF/B-4 (Ref. 7)], adjusting the cross sections to account for cell heterogeneity, deriving correction factors for diffusion theory calculations to effect the neutron streaming through coolant channels, and performing the diffusion code calculations to determine loading reactivity status and reaction rate distributions. Additionally, for the critical experiments, measurements of small sample reactivity coefficients are analyzed utilizing first-order perturbation theory. A preliminary description of the codes and methods involved in this process at GA has been reported by Merrill (Ref. 8).

\subsection{PROCESSING OF ENDF/B-4 BASIC NUCLEAR DATA}

Figure 3-1 shows how basic nuclear data on the ENDF/B tapes are channeled into three components for subsequent use in GGC-5 (Ref. 9), the spectrum computer code in current use at GA for fast reactor analysis. The fine group average GAM data for structural materials and for fuel isotopes in the range above about $7.5 \mathrm{keV}$ are prepared with GFE4 (Ref. 10). The GFE4 program includes an option to average cross sections using a finite-dilution $(1 / E \times[$ - tota1) flux weighting to effect self-shielding of resonances; for each material processed, a dilution factor $\sigma_{0}$ is added to the material $\sigma_{\text {total }}$ to provide total scattering-per-material-atom appropriate to the material dilution in the cell mixture considered. Beforehand estimates of fast-range macroscopic total cross sections are thus required to estabish $\sigma_{0}$ values which w1ll properly shleld the scattering resonances in the 


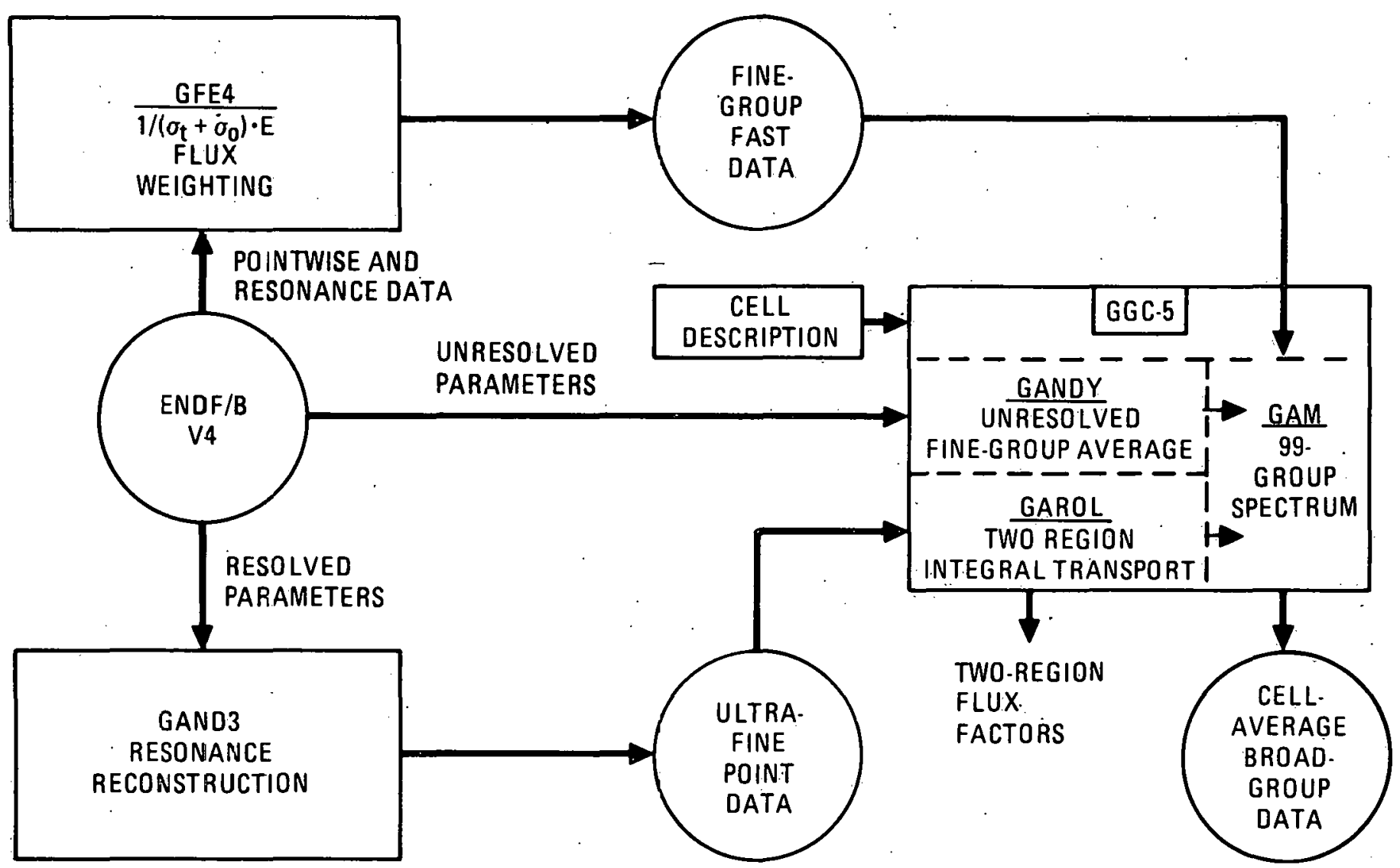

Fig. 3-1. General Atomic cross section generation for fast reactors 
structural elements. This treatment is necessary for accurate prediction of the leakage component of a reactor neutron balance.

The computer code CAND3 (Ref. 10) processes the resolved-resonance parameters on the ENDF/B tapes to reconstruct, by material, cross section variations on a hyperfine energy grid $(>14,000$ points) in the range of 0 to $7.5 \mathrm{keV}$. The resulting GAR tape data are used in the GAROL section of GGC -5 .

The GANDY (Ref. 11) section of GGC-5 utilizes unresolved resonance parameters by material derived from the ENDF/B tapes with separate utility codes.

\subsection{GENERATION OF BROAD GROUP CROSS SECTIONS}

The GAROL section in GGC-5 calculates hyperfine flux spectra in a two-region (fuel/diluent) cell according to integral transport theory and averages cross sections over the fine groups in the resolved range. The method thus accounts for overlapping of resonances for different materials in the fuel region and also for the interactions with structural-material resonances in the diluent region.

The GANDY routine in GGC-5 generates the fine-group cross sections in the unresolved resonance range using the narrow resonance approximation, accounting for heterogeneity by the equivalence principle with appropriate Dancoff factors.

With all ranges of fine-group data available, the GAM section of GGC-5 carries out a fundamental mode solution of the $B_{n}$ equations for a homogenized cell composition. The 99-group flux and higher moments thus generated are then used to collapse the fine-group cross sections to any number of broad-group structures, as dictated by the pending applications. For the Phase III analysis, the basic study reported herein utilized a 10-group structure, but 28-, 4-, and 1-group collapses were generated for 
possible future use. The GAM solution also incorporates input bucklings, constant or varying by broad group, to represent spatial leakage effects on the spectrum. Table 3-1 defines the ten-group energy structure and lists some calculated spectra.

Because of the significant differences in the heterogeneity structure of the three Phase III zone cells, it was considered necessary that separate GGC-5 runs be run for each cell type. (For the power-plant design, a generation of $a^{-}$single cross section set for the average enrichment cell is considered sufficient:) Also, because of the two-region limitation of the GAROL routine; two separate GGC-5 cases were run to generate appropriately shielded cross sections for the $\mathrm{U}-238$ in the $\mathrm{Pu}-\mathrm{U}-\mathrm{Mo}$ column and in the $\mathrm{U}_{3} \mathrm{O}_{8}$ columns of the core zone 1 cell. Similarly, for core zone 2, two separate GGC-5 cases were utilized because of the plutonium/fertile split, but these cases actually had been previously run during the post-analysis of the Phase II assembly, wherein the whole core consisted of the $17 \%$ enrichment, three-drawer cell.

Likewise, for the radial blanket, the axial blanket, and the reflector regions of the Phase III assembly, the adopted multigroup cross sections were derived from GGC-5 cases run prior to the post-analyses of Phase II experiments. In these cases, region 1 of the GAROL cell consisted of an average fertile-material plate with the width as an average of the blanketcell $\mathrm{U}_{3} \mathrm{O}_{8}$ plus depleted-uranium clusters. The slight changes in blanket cell loadings between Phase II and Phase III did not warrant the regeneration of cross sections, although, of course, the newer atomic mixing densities were used in the neutronics calculations.

Input specifications for the new GGC-5 cases run in the Phase III. analysis are given in the Appendix. These include the cases for the zone 1 plate and pin cells and for the zone 3 core cell. The specifications for the previously run cases were included in the report on the GA steam-worth analysis for Phase II (Ref. 5). 
TABLE 3-1

NEUTRON CROSS SECTION GROUP STRUCTURE AND COMPARISONS OF CALCULATED CORE CENTER SPECTRA

\begin{tabular}{|c|c|c|c|c|c|c|c|}
\hline \multirow[b]{2}{*}{$\begin{array}{l}\text { Group } \\
\text { No. }\end{array}$} & \multirow{2}{*}{$\begin{array}{l}\text { Lower } \\
\text { Energy } \\
\text { Limit (a) } \\
\quad(\mathrm{eV})\end{array}$} & \multirow{2}{*}{$\begin{array}{l}\text { Group } \\
\text { Width } \\
\text { Lethargy } \\
\text { Units }\end{array}$} & \multicolumn{3}{|c|}{$\begin{array}{l}\text { Calculated Real Flux Spectra } \\
\text { at Core Center (\% in group) }\end{array}$} & \multirow{2}{*}{$\begin{array}{l}\text { Calculated } \\
\text { Adjoint Spectrum at (b) } \\
\text { Reference Core Center }\end{array}$} & \multirow{2}{*}{$\begin{array}{l}\text { Fission } \\
\text { Spectrum } \\
\text { Used } \\
(\% \text { in group })\end{array}$} \\
\hline & & & $\begin{array}{c}\text { Reference } \\
\mathrm{RZ} \text { Geometry }\end{array}$ & $\begin{array}{l}\text { Reference } \\
\text { XY Geometry }\end{array}$ & $\begin{array}{l}\text { Central } \\
\text { Pin Zone }\end{array}$ & & \\
\hline 1 & $3.67 \times 10^{6}$ & 1.40 & 1.495 & 1.496 & 1.511 & 1.2672 & 15.143 \\
\hline 2 & $1.353 \times 10^{6}$ & 1.00 & 7.348 & 7.350 & 7.416 & 1.0059 & 43.193 \\
\hline 3 & $4.979 \times 10^{5}$ & 1.00 & 17.734 & 17.738 & 17.962 & 0.9072 & 28.599 \\
\hline 4 & $1.832 \times 10^{5}$ & 1.00 & 20.667 & 21.669 & 20.916 & 0.8569 & 9.7392 \\
\hline 5 & $6.738 \times 10^{4}$ & 1.00 & 21.292 & 21.290 & 21.363 & 0.8978 & 2.5464 \\
\hline 6 & $2.479 \times 10^{4}$ & 1.00 & 14.063 & $1 \dot{4} .060$ & 14.139 & 0.9846 & 0.6025 \\
\hline 7 & $9.119 \times 10^{3}$ & 1.00 & 10.093 & 10.090 & 9.801 & 1.0569 & 0.13737 \\
\hline 8 & $3.355 \times 10^{3}$ & 1.00 & 4.066 & $\dot{4} .065$ & 3.915 & 1.1157 & $3.089 \times 10^{-2}$ \\
\hline 9 & $4.540 \times 10^{2}$ & 2.00 & 3.009 & 3.008 & 2.818 & 1.3313 & $8.458 \times 10^{-3}$ \\
\hline 10 & $4.140 \times 10^{-1}$ & 7.00 & D. 233 & 0.234 & 0.159 & 1.4378 & $4.436 \times 10^{-4}$ \\
\hline
\end{tabular}

(a) Upper boundary for group 1 at $14.918 \mathrm{MeV}$.

(b) Normalized to unity for average fission spectrum neutron. 


\subsection{HETEROGENEITY ADJUSTMENTS}

Figure 3-2 charts the additional procedures involved in correcting the cross sections for the effects of the heterogeneous structure of the ZPR-9 cell loadings, either the plate type or the pin type. The various material regions of the cell are explicitly modeled in a one-dimensional discrete-ordinates calculation using the code DTFX ${ }^{*}$. Macroscopic in-plate (or in-pin) cross sections for the cell regions are extracted from the pertinent core zone GGC-5 outputs. The group-wise ratios of material region fluxes to the cell average fluxes thus calculated are the heterogeneity (or flux-advantage) factors for correcting the cross sections used in the homogenized core regions in the diffusion calculations. For the blanket zones, such corrections were not generated, since it has been found in the past that the factors are near unity and have insignificant effects on calculated reactivities.

For the plate core zone cell calculations, using the slab geometry option in DTFX, the distinct regions modeled included the $\mathrm{Pu}-\mathrm{U}-\mathrm{Mo}, \mathrm{U}_{3} \mathrm{O}_{8}$, $\mathrm{Fe}_{2} \mathrm{O}_{3}$, the clads of the plutonium and of the voids, the low density voids, and the vertical matrix elements; the horizontal matrix structure was smeared into the vertical regions of steel and the voids. Transverse leakage was represented by group dependent pseudo-adsorber terms $\left(D^{2}\right)$ added uniformly to all regions to avoid difficulties from utilizing input bucklings with low-density channels. The group $\mathrm{DB}^{2}$ values used for the pseudo-adsorption were derived from preliminary diffusion calculations for the assembly.

For the pin cell configuration [Fig. 2-2(b)], which was loaded as a special experiment into a central region of core zone 1 , the cylindrical geometry option of DTFX was employed. Here, a three-region model was defined with the central region as the fuel pin $\left(\mathrm{PuO}_{2} \cdot \mathrm{UO}_{2}\right)$ enclosed in steel

\footnotetext{
${ }^{*}$ DTFX is an extensive GA revision to the one-dimensional transport theory code IDFX-A (Ref. 12).
} 


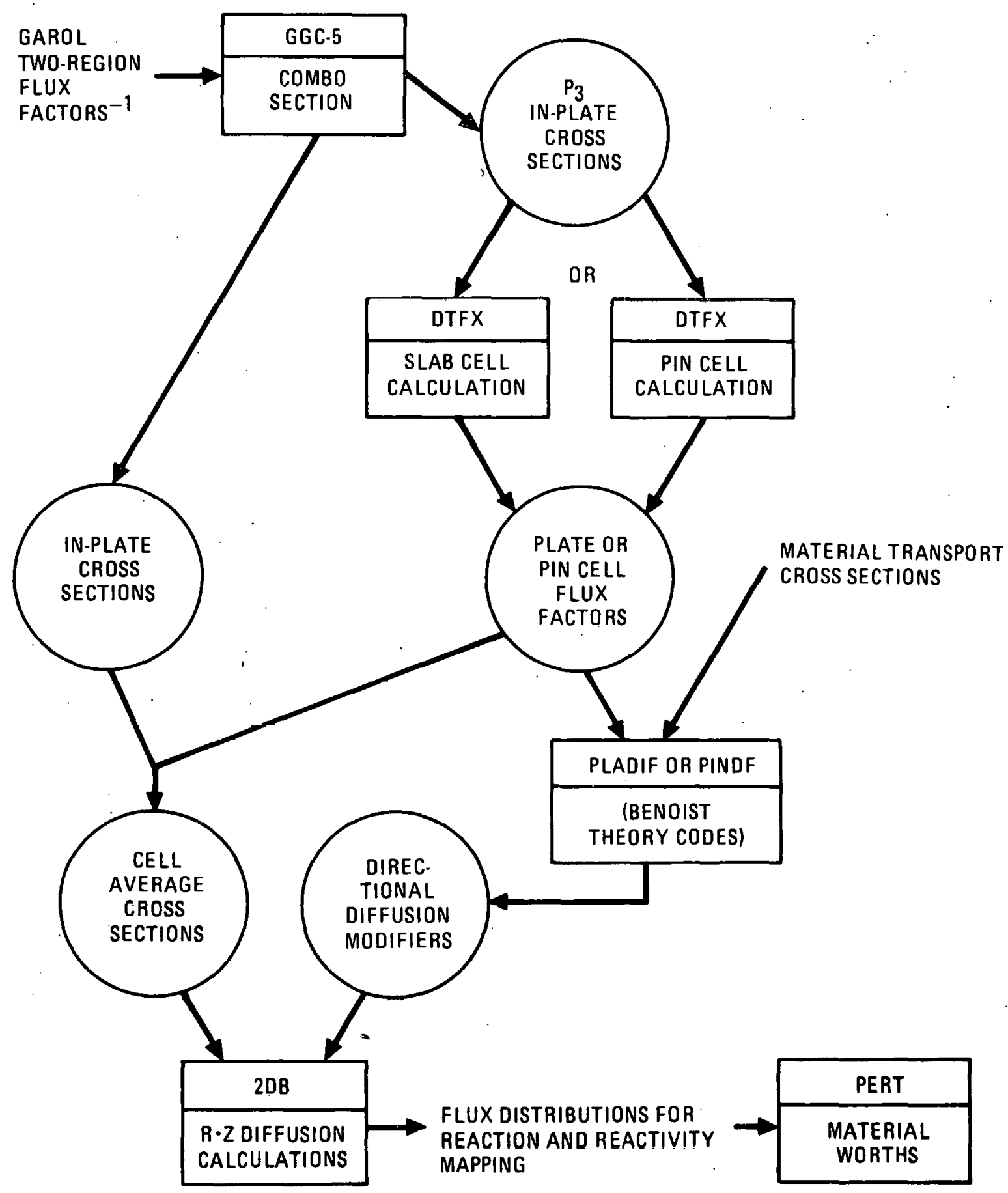

Fig. 3-2. Adjustments of cross sections for cell heterogeneity and streaming 
cladding and surrounded by a diluent region of the coolant channel with smeared-in steel of the calandria jacket and the matrix.

For the Phase 3 cell calculations, all of the DTFX cases used orderP3 anisotropic cross sections and an order-16, half-range Gauss-Legendre quadrature (Ref. 13) (designated $\mathrm{S}_{16}$-double $\mathrm{Pn}$, or $\mathrm{S}_{16} \mathrm{DPn}$ ). A description of the models adopted is given in Appendix. Typical results of the calculations are given in Table 3-2, listing the derived flux advantage factors by group for the principal fuel and fertile materials in the three plate core cells and in the pin core loading. Comparisons of the various data columns in the table reveal the much stronger heterogeneity influence in the plate $Z P R$ cells than in the pin cell, which closer resembles a power core.

\subsection{NEUTRON STREAMING EFFECTS}

Conventional diffusion-theory calculations using homogeneous isotropic diffusion parameters are known to substantially underpredict neutron leakage through lattices with void or near-void coolant channels, as found in the GCFR or its plate mockup. Benoist (Ref. 14) provided a theory for deriving directional-dependent coefficients which allows treatment of such anisotropic leakage within the framework of diffusion theory. The code PLADIF, a GA adaptation of an ANL code by Kier (Ref. 15), uses the Benoist method to evaluate modifiers to cell average diffusion coefficients for directions parallel and perpendicular to the plates in a one-dimensional slab geometry cell as pertains to the ZPR drawer loadings. At GA, the computer code PINDF3. (Ref. 16), also based on the Benoist method, is routinely employed for determination of the anisotropic streaming corrections for rod GCFR fuel assembly lattices. Thus, PINDF3 is applicable for analyzing the streaming properties of the calandria loading used in Phase III. A review of the Benoist algorithms used in the PLADIF code can be found in the Appendix of the Phase II steam study report (Ref.5). 
TABLE $3-2$

COMPARISON OF HETEROGENEITY CORRECTION FACTORS DERIVED FOR CROSS SECTIONS USED IN PHASE III CALCULATIONS

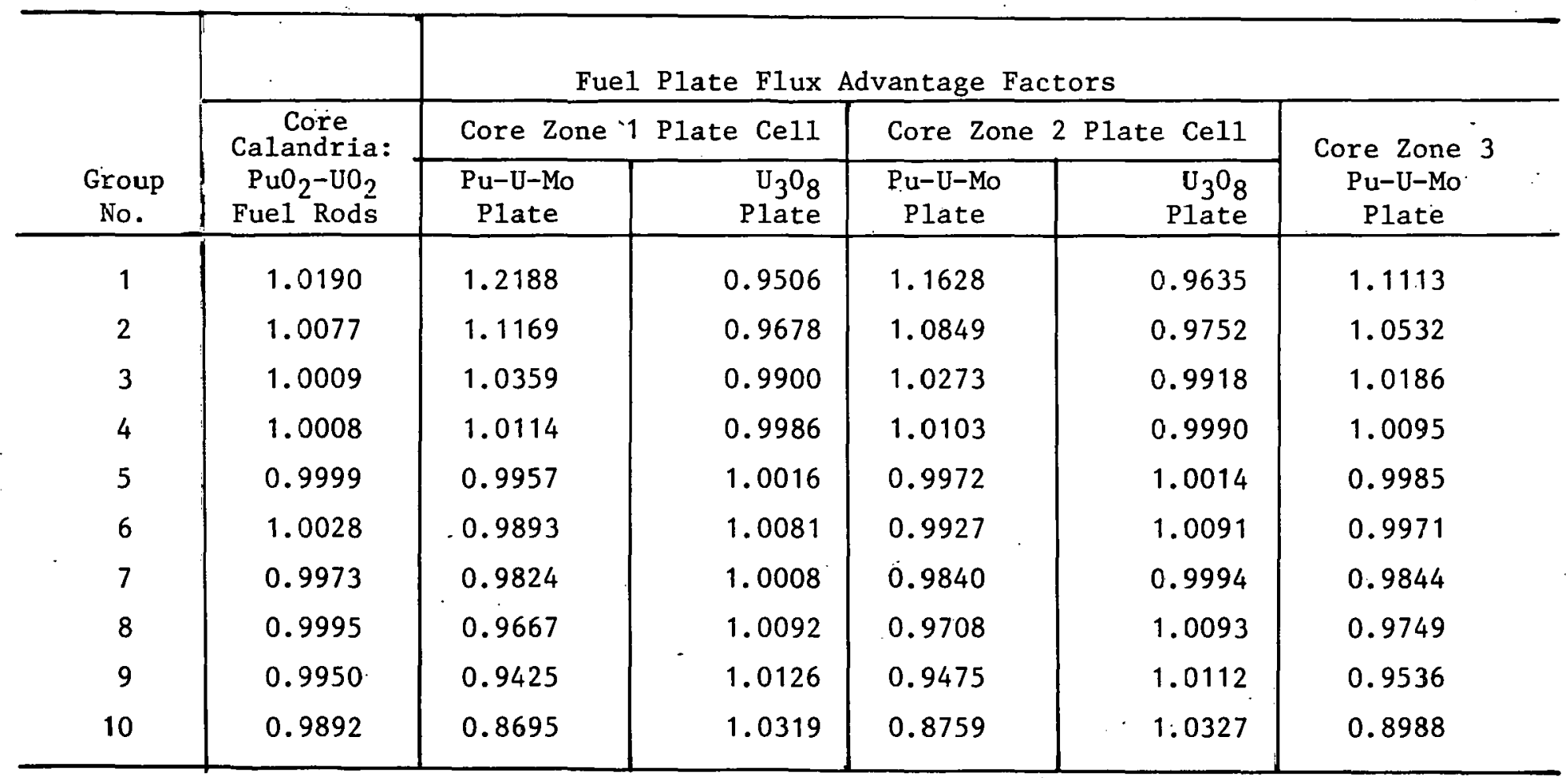


As shown in Fig. 3-2, the input to the streaming modifier code includes transport cross sections for the material regions of the cell and the DTFX output cell flux distributions. For the PLADIF code, the cell descriptions are similar to those used in the DTFX slab models, except that plate densities are smeared over the full height of the $Z P R$ unit matrix $[5.5245 \mathrm{~cm}$ (2.175 in.)], and the horizontal structure is uniformly distributed over the full cell; thus, the voids are assigned a steel density on the order of 5 vol \%.

The PINDF 3 code utilizes a two-region-only model, and for the. Phase III pin zone case, the central region contained a smear of the fuel pin with its cladding, and the outer region was the diluted-steel plus vold mixture used for the pin cell DTFX case. As found later, this procedure probably overestimates the obstructions to streaming in the coolant channels and, thus, underestimates the anisotropic diffusion modifiers.

PLADIF problems were run in the ten-energy-group structure for ful1-width models of each of the three plate core zone cells, for each of the three differing axial blanket zone cells, and for the radial blanket ce11. A PINDF 3 case was needed for each of the core loaded and blanket loaded calandria cells. Table 3-3 lists the modifiers given by these Benoist theory calculations, expressing the ratios of the cell bidirectional diffusion coefficients to the normal homogenized media isotropic diffusion coefficients. Comparison of the data for the pin and plate loadings shows substantially higher streaming corrections for the rectangular ZPR void channels than for rod lattice voids.

Diffusion theory codes at GA have been modified to use directional-dependent diffusion coefficient modifiers to effect the preferential leakage, or streaming, through the coolant channels in either pin or plate geometry. For the calculations in R-Z geometry for Phase III, the PLADIF output parallel modifiers $\left(D_{\|}\right)$were used for the axial $(Z)$ direction, and arithmetic averages of the parallel $\left(D_{\|}\right)$and perpendicular $\left(D_{\perp}\right)$ parameters were used in the radial (R) direction. In the XY-geometry 
TABLE 3-3

ANISOTROPIC DIFFUSION COEFFICIENT MODIFIERS FOR PHASE III ANALYSIS

\begin{tabular}{|c|c|c|c|c|c|c|c|c|c|}
\hline \multirow[b]{2}{*}{$\begin{array}{l}\text { Group } \\
\text { No. }\end{array}$} & \multirow{2}{*}{$\begin{array}{c}\text { Core } \\
\text { Zorıe } 1 \\
\text { Calandria }\end{array}$} & \multicolumn{3}{|c|}{ Core Plate Cells } & \multirow{2}{*}{$\begin{array}{c}\text { Axial } \\
\text { Blanket } \\
\text { Calandria }\end{array}$} & \multicolumn{3}{|c|}{ Plate Axial Blanket } & \multirow[b]{2}{*}{$\begin{array}{l}\text { Radial } \\
\text { Blanket }\end{array}$} \\
\hline & & $\begin{array}{c}\text { Zone } \\
1\end{array}$ & $\begin{array}{l}\text { Zone } \\
2\end{array}$ & $\begin{array}{c}\text { Zone } \\
3\end{array}$ & & $\begin{array}{c}\text { Zone } \\
1\end{array}$ & $\begin{array}{l}\text { Zone } \\
2\end{array}$ & $\begin{array}{c}\text { Zone } \\
3\end{array}$ & \\
\hline $\begin{array}{l}\text { Parallel to } \\
\text { plates or rods }\end{array}$ & & & & & & & & & \\
\hline 1 & 1.0202 & 1.0891 & 1.0882 & 1.0817 & 1.0184 & 1.0550 & 1.0483 & 1.0423 & 1.0268 \\
\hline 2 & 1.0247 & 1.0897 & 1.0872 & 1.0818 & 1.0226 & 1.0664 & 1.0589 & 1.0510 & 1.0333 \\
\hline 3 & 1.0359 & 1.1113 & 1.1038 & 1.0993 & 1.0330 & 1.0991 & 1.0882 & 1.0802 & 1.0605 \\
\hline 4 & 1.0558 & 1.1619 & 1.1483 & 1.1379 & 1.0520 & 1.1504 & 1.1340 & 1.1215 & 1.0961 \\
\hline 5 & 1.0584 & 1.1670 & 1.1562 & 1.1480 & 1.0537 & 1.1508 & 1.1335 & 1.1199 & 1.0858 \\
\hline 6 & 1.0652 & 1.1872 & 1.1807 & 1.1693 & 1.0596 & 1.1565 & 1.1355 & 1.1203 & 1.0746 \\
\hline 7 & 1.0727 & 1.1805 & 1. 1656 & 1.1598 & 1.0660 & 1.1702 & 1.1505 & 1.1354 & 1.0957 \\
\hline 8 & 1.0783 & 1.2057 & 1.2022 & 1.1859 & 1.0712 & 1.1744 & 1. 1519 & 1.1395 & 1.0832 \\
\hline 9 & 1.0780 & 1.2017 & 1.2012 & 1.1869 & 1.0669 & 1.1670 & 1. 1445 & 1. 1298 & 1.0763 \\
\hline 10 & 1.0857 & 1.2155 & 1.2255 & 1.2082 & 1.0681 & 1.1637 & 1.1417 & 1. 1286 & 1.0758 \\
\hline $\begin{array}{l}\text { Perpendicular to } \\
\text { plates or rods }\end{array}$ & & & & & & & & & \\
\hline 1 & 1.0100 & 1.0284 & 1.0298 & 1.0272 & 1.0092 & 1.0014 & 1.0014 & 1.0011 & 1.0010 \\
\hline 2 & 1.0123 & 1.0159 & 1.0174 & 1.0156 & 1.0113 & 1.0020 & 1.0019 & 1.0014 & 1.0014 \\
\hline 3 & 1.0178 & 1.0075 & 1.0038 & 1.0093 & 1.0164 & 1.0033 & 1.0033 & 1.0026 & 1.0028 \\
\hline
\end{tabular}


TABLE 3-3 (Continued)

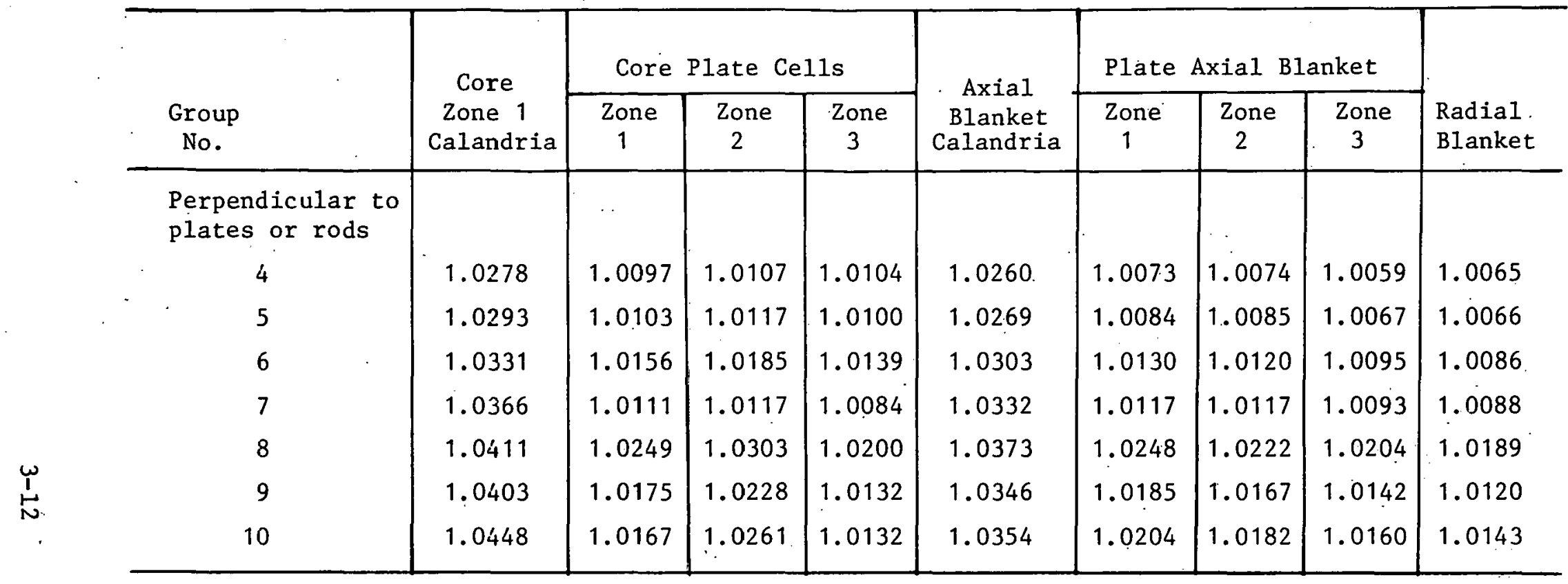


2DB (Ref. 17) cases, the perpendicular coefficients were used in the $\mathrm{X}$-direction and the parallel coefficients in the Y-direction.

\subsection{DIFFUSION THEORY CALCULATIONS}

The basic neutronics calculations in this Phase III analysis were carried out with a GA modification of the two-dimensional diffusion theory code 2DB (Ref. 17). The RZ and XY models adopted for the Phase III reference and other configurations are specified in the Appendix, including details on the mesh structure. Direct solution 2DB cases provided the configuration eigenvalues and the real flux distributions for determining reaction rate and power profiles. For the basic reference, an adjoint solution was also obtained as required for calculations of delayed neutron effectiveness and the material reactivity coefficients.

\subsection{PERTURBATION THEORY CALCULATIONS}

The first-order perturbation theory code PERT (Ref. 18), an ancillary package to the 2DB code, was utilized for the above-mentioned determinations of Beta-effective and material worths. For these calculations, PERT requires both real and adjoint fluxes and,input delayed neutron parameters. The flux solutions for only the $\mathrm{RZ}$ reference configurations were applied for the perturbation calculations.

The isotopic delayed neutron parameters adopted for input to PERT were identical with the ENDF/B-4 data reported by Pond (Ref. 2); this included five families of six-delay-group parameters (by the five major isotopes) and the associated isotopic yields and delayed neutron spectra. Results of the GA 10-group evaluation of the average Phase III delayed neutron parameters are given in Table 3-4. The GA assessment of the reactivity conversion factor ( 933.9 Ih per $\% \Delta k / k$ ), necessary for correlation of measured and calculated reactivity changes, is about $2 \%$ lower than that obtained by the ANL 29-group analysis. 
TABLE 3-4

CALCULATED DELAYED NEUTRON PARAMETERS FOR REFERENCE PHASE III GCFR CRITICAL ASSEMBLY

\begin{tabular}{|c|c|c|c|c|c|c|c|c|}
\hline \multirow{3}{*}{$\begin{array}{c}\text { Family } \\
\text { No. }\end{array}$} & \multirow[b]{3}{*}{ Components } & \multicolumn{7}{|c|}{ Delayed Neutron Fractions $\times 10^{5}$} \\
\hline & & \multicolumn{6}{|c|}{ Delay Group No. } & \multirow{2}{*}{$\begin{array}{r}\text { Isotope } \\
\text { Totals }\end{array}$} \\
\hline & & 1 & 2 & 3 & 4 & 5 & 6 & \\
\hline 1 & $\mathrm{U}-235$ & 0.2248 & 1.3704 & 1.1312 & 2.4669 & 0.7758 & 0.1576 & 6.1267 \\
\hline 2 & $\mathrm{U}-238$ & 2.2679 & 25.723 & 28.724 & 68.918 & $39.753^{\circ}$ & 13.251 & 178.6369 \\
\hline 3 & $\mathrm{Pu}-239, \mathrm{PU}-238$ & 5.5668 & 43.648 & 31.750 & 48.687 & 15.289 & 5.1953 & 150.136 \\
\hline 4 & $\mathrm{Pu}-240, \mathrm{Pu}-242$ & 0.1873 & 1.9744 & 1.3006 & 2.4249 & 0.8963 & 0.2004 & 6.9839 \\
\hline 5 & $\mathrm{Pu}-241, \mathrm{Am}-241$ & 0.0729 & 1.7765 & 1.2654 & 2.8806 & 1.3443 & 0.1182 & 7.4579 \\
\hline \multicolumn{2}{|c|}{ Group totals } & 8.3197 & 74.4923 & $64 . .17 \cdot 12$ & 125.3744 & 58.0584 & 18.9225 & 349.34 \\
\hline \multicolumn{2}{|c|}{$\begin{array}{l}\text { Effective decay } \\
\text { constant } \lambda, s^{-1}\end{array}$} & 0.01299 & 0.03144 & 0.13599 & 0.34691 & 1.3742 & 3.800 & \\
\hline
\end{tabular}

Sumary: Effective delayed fraction $=3.4934 \times 10^{-3}$

$$
\text { Inhour }=1.0708 \times 10^{-5} \Delta \mathrm{k} / \mathrm{k}
$$

Conversion factors $=933.9 \mathrm{Ih} / \% \mathrm{k}$

$326.2 \mathrm{Ih} / \$$

Generation time $=40.99 \times 10^{-8} \mathrm{~s}$ 


\section{CRITICALITY CALCULATIONS}

Table 4-1 summarizes the results of the RZ- and XY-geometry 2DB calculations carried out on the various configurations defined in the Table 2-2 1ist of measured criticality states. For some of the configurations, the calculations were repeated with the diffusion modifiers deleted (using normal isotropic diffusion parameters) as an assessment of the worth of streaming. In Table 4-2, calculated eigenvalues are compared with measured results, and the bias of the calculational procedure is established. Specific models and experiments are discussed below.

\subsection{REFERENCE CONFIGURATION, CYLINDRICAL GEOMETRY}

Cases 1, 2, and 3 in Table 4-1 are for the reference Phase III configuration calculated in $\mathrm{KZ}$ geometry with progressive additions of the neitron streduling currecluns. The total screaming correction from case 1 to case 3 amounts to $-1.64 \% \Delta \mathrm{k} / \mathrm{k}$, and according to case 2 , the effect is composed of $-0.95 \% \Delta \mathrm{k} / \mathrm{k}$ due to axial streaming and $-0.69 \% \Delta \mathrm{k} / \mathrm{k}$ due to radial streaming. Similar components were evaluated for the Phase II assembly analysis ( $-1.7 \% \Delta k / k$ total) (Ref. 5).

Table 4-2 shows that the calculated $k$ for the Phase III GCFR reference configuration given by the RZ-2DB case is lower than the measured $\mathrm{k}$ by $1.37 \% \Delta \mathrm{k} / \mathrm{k}$, or the calculated to experimental ratio ( $\mathrm{C} / \mathrm{E}$ ) for the eigenvalue evaluation is 0.9864 . Compared with the ANL-analysis $\mathrm{C} / \mathrm{E}$ of about 0.983 , there is a difference of $0.3 \%$, which is typical of past GA/ANL $k$-calculation comparisons.

\subsection{REFERENCE CONFIGURATION, XY GEOMETRY}

For the XY-model 2DB calculations, the input axial-leakage parameters were $\mathrm{DB}^{2}$ pseudo-absorber cross sections, by group and by radial zone, 
TABLE 4-1

EIGENVALUES CALCULATED USING TWO-DIMENSIONAL DIFFUSION THEORY FOR REFERENCE LOADINGS OF PHASE III GCFR CRITICAL ASSEMBLY

\begin{tabular}{|c|c|c|c|c|c|c|}
\hline $\begin{array}{l}\text { 2DB } \\
\text { Case } \\
\text { No. }\end{array}$ & $\begin{array}{l}\text { Configuration; } \\
\text { Model } \\
\text { Description }\end{array}$ & $\begin{array}{l}\text { No. of Core } \\
\text { Drawers per } \\
\text { Half }\end{array}$ & \begin{tabular}{|} 
Core Outer \\
Radius \\
$(\mathrm{cm})$
\end{tabular} & $\begin{array}{l}\text { 2DB } \\
\text { Geometry }\end{array}$ & $\begin{array}{l}\text { Regional } \\
\text { Diffusion } \\
\text { Coefficient } \\
\text { Modifiers } \\
\text { Used }\end{array}$ & $\begin{array}{l}\text { Calculated } \\
\text { k } \\
\left( \pm 2 \times 10^{-5}\right)\end{array}$ \\
\hline 1 & $\begin{array}{l}\text { Reference loading; with- } \\
\text { out streaming }\end{array}$ & 513 & 70.60 & $\mathrm{RZ}$ & $\begin{array}{l}\text { None; normal isotropic } \\
\mathrm{D} \text { values for homogene- } \\
\text { ous media }\end{array}$ & 1.00568 \\
\hline 2 & $\begin{array}{l}\text { Reference; with axial } \\
\text { streaming correction }\end{array}$ & 513 & 70.60 & $\mathrm{RZ}$. & $\begin{array}{l}\text { Isotropic radial, } \\
\text { Benoist axial }\end{array}$ & 0.99620 \\
\hline 3 & $\begin{array}{l}\text { Reference; with full } \\
\text { streaming correction }\end{array}$ & 513 & 70.60 & RZ & $\begin{array}{l}\text { Benoist radial } \\
\text { axial }\end{array}$ & 0.98937 \\
\hline 4 & $\begin{array}{l}\text { Reference; midplane view, } \\
\text { without streaming }\end{array}$ & 513 & $70.60^{(b)}$ & $\mathrm{XY}$ & $\begin{array}{l}\text { None; normal isotropic } \\
D \text { values for vertical } \\
\text { and horizontal }(c)\end{array}$ & 0.99554 \\
\hline 6 & $\begin{array}{l}\text { Edge-worth study; mid- } \\
\text { plane view, full } \\
\text { streaming }\end{array}$ & 509 & $70.32^{(b)}$ & XY & $\begin{array}{l}\text { Benoist } X \text { and } Y \text { (as } \\
\text { for case } 5 \text { ) }\end{array}$ & 0.98577 \\
\hline 7 & $\begin{array}{l}\text { Pin-zone study; plate- } \\
\text { loaded starting case, } \\
\text { full streaming }\end{array}$ & 511 & 70.46 & $\mathrm{RZ}$ & $\begin{array}{l}\text { Benoist radial and } \\
\text { axial (for plate } \\
\text { cells) }\end{array}$ & 0.98801 \\
\hline
\end{tabular}

(a) Radial modifiers derived as average of parallel and perpendicular modifiers from plate-cell PLADIF calculations.

(b) On equivalent area basis.

(c) However, axial leakage parameters (DB ${ }^{2}$ derived from full-streaming RZ calculation (case 3 ). 
TABLE 4-2

COMPARISON OF MEASURED VERSUS CALCULATED EIGENVALUES FOR PHASE III GCFR ASSEMBLY AND ASSESSMENT OF ANALYTICAL BIAS

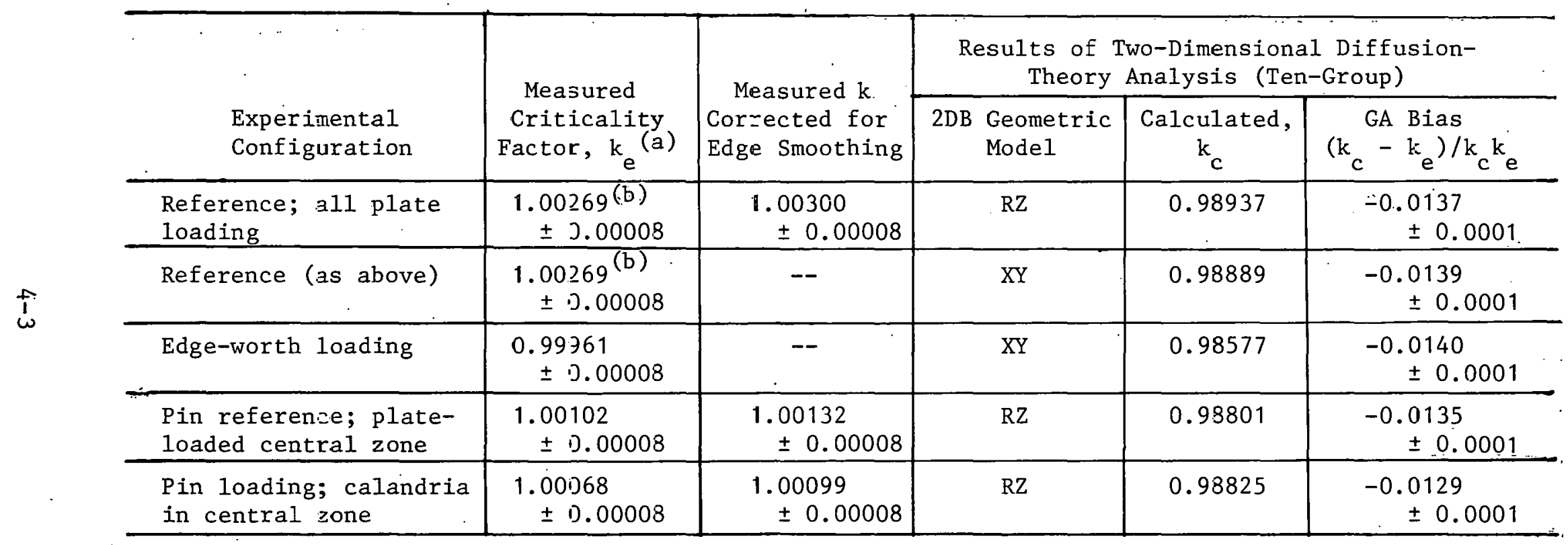

(a) Adjisted for worth of Pu-241 decay to represent loaded fissile plutonium as of $7 / 1 / 75$, the date corresponding to the compositions used in the analyses.

(b) Average of measuremen二s on different dates. 
derived for a thin midplane region from the corresponding RZ-geometry 2DB case (case 3 in Table 4-1) with full accounting of the axial streaming. This RZ-to-XY procedure thus represents a three-dimensional synthesis calculation to better correlate against the real-world, stepped-outline ZPR geometry. Cases 4 and 5 in Table 4-1 give the results of the reference $X Y$ calculations using normal diffusion coefficients and using full X-plus-Y streaming corrections. The 4-to-5 difference $(-0.68 \% \Delta \mathrm{k} / \mathrm{k})$ agrees well with the radial streaming worth assessment given by the $\mathrm{RZ}$ study above, thus validating the procedure of averaging parallel and perpendicular modifiers to produce radial modifiers.

The eigenvalue given by the XY 2DB calculation differs from the corresponding $R Z$ result by $-0.049 \% \Delta k / k$, which indicates that the core-edge stepped outline reduces reactivity by about $45 \mathrm{Ih}$. A semiempirical evaluation of this edge-smoothing correction by ANL cites an edge-smoothing worth of about half of this, 25 Ih (to correct the experimental reactivity to a configuration with a true circular outline). Thus, for the threedimensional synthesis technique employed here, a common procedure in GCFR core analyses, the total calculational discrepancy rises to $-1.40 \% \Delta \mathrm{k} / \mathrm{k}$.

\subsection{CORE-EDGE FUEL WORTH}

As mentioned earlier, an experiment was carried out with blanket-for-fuel exchanges to establish a core-edge fuel reactivity coefficient. The experimental change of configuration, replacing one zone 3 core drawer per quandrant per half with radial blanket drawers, was duplicated in the $\mathrm{XY}-2 \mathrm{DB}$ case 6 in Table 4-1. The calculated exchange total worth, $-0.320 \% \Delta \mathrm{k} / \mathrm{k}$ or $-299 \mathrm{Ih}$, agrees very well with the measured value of $-295 \mathrm{Ih}$.

\subsection{PIN-ZONE REACTIVITY WORTH}

Table 4-2 shows that the calculational-to-experimental discrepancy on eigenvalue is reduced to $-1.29 \% \Delta k / k$ when the central region of core zone 1 
is reconstructed with pin fuel. This implies that analyses for completely rodded fuel systems will carry a discrepancy less than that obtained in the calculations on the plate systems. A complete discussion of the pin-fuel experiment is given in Section 9. 


\section{SMALL SAMPLE REACTIVITY COEFFICIENTS}

The worths of materials in dilute concentrations are measured at various locations in the core and blankets of the ZPR criticals by traversing small material samples through a guide tube installed through the reactor; the induced sma11 reactivity effects, as evidenced by power variations or automated control-rod compensation, provide specific worths, in inhours/kilogram, which relate the relative importance of the material toward maintaining criticality. The analyses of such measurements is carried out using first-order perturhation theory, the validity of which depends on an assumption of insiginificant changes in the real-flux and importance-flux spectra being introducted by the perturbation sample. Discussed below are calculated worths for several materials at the core center, comparisons with the measured central worths, and comparisons of calculated and measured worth profiles radially through the core.

\subsection{CENTRAI WORTH CALCULATIONS}

The cross sections for core-constituent materials used in the perturbation theory calculations to represent the thin samples are not the same as those used in the $2 \mathrm{DB}$ calculations to generate the required real and adjoint fluxes. Rather, they are derived by including duplicates of the plate-region isotopes in the GGC-5 calculations, homogenized over the cell at dilite concentrations, to be broad-group averaged using the 99-group GAM fine spectrum and then used without adding any heterogeneity adjustments from the DTFX cell calculations. For the nonconstituent materials, extra elements and isotopes are added to the specific core-cell GGC-5 cases at infinite diJution to obtain group cross sections averaged over the homogenized-cell spectrum according to the GAM calculation.

Table 5-1 lists the results of the 10-group PERT calculations for the worths of numerous pure elements and isotopes using the reference- 
TABLE 5-1

COMPARISON OF ANL AND GA CENTRAL WORTH CALCULATIONS

FOR PHASE III GCFR CRITICAL ASSEMBLY

\begin{tabular}{|c|c|c|c|}
\hline \multirow[b]{2}{*}{$\begin{array}{l}\text { Element or } \\
\text { Isotope }\end{array}$} & \multicolumn{2}{|c|}{$\begin{array}{c}\text { Calculated Core Center } \\
\text { Reactivity Coefficients } \\
\text { (Ih/kg) }\end{array}$} & \multirow{2}{*}{$\begin{array}{l}\text { GA } \\
\text { Calculated } \\
\text { To } \\
\text { Experimental } \\
\text { Ratio, C/E }(\mathrm{b})\end{array}$} \\
\hline & $\begin{array}{l}\text { ANL 29-Group } \\
\text { Analysis }\end{array}$ & $\begin{array}{c}\text { GA Ten Group } \\
\text { Analysis }\end{array}$ & \\
\hline $\mathrm{H}$ & -316.8 & -1396 & -25 \\
\hline $\mathrm{He}-4$ & -154.6 & -132.4 & -- \\
\hline Li-6 & -1735 & -1722 & $1.1 \cdot 3$ \\
\hline $\mathrm{Be}$ & -49.04 & -45.92 & -- \\
\hline$B-10$ & -2282 & -2245 & 1.01 \\
\hline B-11 & -31.19 & -31.47 & -- \\
\hline$C-12$ & -27.66 & -26.74 & - \\
\hline $0-16$ & -17.09 & -15.82 & -- \\
\hline$A 1-27$ & -9.191 & -7.577 & -- \\
\hline $\mathrm{Cr}$ & -6.460 & -5.838 & -- \\
\hline Mn & -12.73 & -13.39 & 1.84 \\
\hline $\mathrm{Fe}$ & -5.248 & -5.193 & 1.34 \\
\hline $\mathrm{Ni}$ & -8.847 & -8.450 & -- \\
\hline Mo & -17.38 & -15.65 & -- \\
\hline Eu-153 & -127.8 & -119.5 & -- \\
\hline $\mathrm{Ta}-181$ & -42.59 & -40.10 & -- \\
\hline Th & -16.82 & -16.17 & - \\
\hline $\mathrm{U}-233$ & 221.2 & 219.5 & 1.14 \\
\hline $\mathrm{U}-235$ & 133.2 & 129.8 & 1.16 \\
\hline $\mathrm{U}-238$ & -8.643 & -8.671 & 1.09 \\
\hline $\mathrm{Pu}-238$ & 102.29 & 98.44 & -- \\
\hline $\mathrm{Pu}-239$ & 168.7 & 164.6 & 1.12 \\
\hline $\mathrm{Pu}-240$ & 22.85 & 22.53 & 1.13 \\
\hline $\mathrm{Pu}-241$ & 240.1 & 232.4 & -- \\
\hline $\mathrm{Pu}-242$ & 18.08 & 18.27 & -- \\
\hline $\mathrm{Am}-241$ & 2.733 & 2.748 & -- \\
\hline
\end{tabular}

(a) At centermost mesh interval of RZ diffusion calculations.

(b) From Table 5-2 data for material samples at offset locations of central worth measurements. 
configuration fluxes. Table 5-1 includes the comparable results of ANL 29-group calculations and shows identical results for most materials when considering the difference between ANL- and GA-adopted conversion. factors. The deviations of the 10-group results from the 28-group counterparts become more and more significant for the lighter elements where the downscattering contribution to worth becomes predominant.

\subsection{COMPARISONS WITH MEASURED CENTRAL WORTHS}

Table 5-2 lists the results of the sample-worth.measurements at the center of the Phase III core for major reactor-constituent materials. Most of the samples contained isotopic mixture and alloy impurities; thus, for comparison calculations, the sample cross-sections used were prepared from the appropriate blend of the cross sections of the mixture constituents. The calculational bias (C/E) for the fissile sample worths 1.12 to 1.16 , given by this GA analysis, are about 3\% lower than the corresponding ANL results. Also, these $\mathrm{C} / \mathrm{E}$ values are somewhat lower than observed for the comparable studies of the Phase I and Phase II GCFR assemblies.

For the fertile-material samples, the lower $\mathrm{C} / \mathrm{E}$ for $\mathrm{U}-238$ than for the fissile samples is consistent with past analyses. It is surprising to note the large difference between the $\mathrm{C} / \mathrm{Es}$ for the two poison materials, $\mathrm{B}-10$ and Li-6 ( 1.01 and 1.13, respectively). Further study is warranted to investigate possible errors in one or another of these standard reaction rate cross section evaluations. More probably there are significant selfshielding effects which have not. been accounted for.

As in the past, the $\mathrm{C} / \mathrm{E}$ values for structural materials are larger than for fuel components. Also, the $1.84 \mathrm{C} / \mathrm{E}$ discrepancy for manganese suggests large errors in the basic manganese data or that shielding considerations are overlooked. For the hydrugeneous material samples, the first-order treatment of worth calculations is completely useless, as was expected. 
TABLE 5-2

COMPARISONS OF MEASLRED AND CALCULATED WORTHS OF MATERIAL SAMPIES AT CENTER OF PHASE III CORE

\begin{tabular}{|c|c|c|c|c|c|}
\hline \multirow[b]{2}{*}{$\begin{array}{l}\text { Material } \\
\text { Class }\end{array}$} & \multicolumn{2}{|c|}{ Sample Description (a) } & \multicolumn{2}{|c|}{ Sample Worth $(I h / k g)$} & \multirow{2}{*}{$\begin{array}{c}\text { Calculated } \\
\text { to Experi- } \\
\text { mental Ratio, C/E }\end{array}$} \\
\hline & $\begin{array}{l}\text { ANL } \\
\text { I.D. (b) }\end{array}$ & $\begin{array}{l}\text { Principal } \\
\text { Isotope (wt \%) }\end{array}$ & Calculated $^{(c)}$ & Measured $(d)$ & \\
\hline \multirow[t]{2}{*}{ Fissile } & MB 10 & $\mathrm{Pu}-239 \quad(96.9)$ & 158.7 & $141.7 \pm 1.3$ & $1.120 \pm 0.010$ \\
\hline & $\dot{U}-233-3$ & $\mathrm{U}-233(99.0)$ & 215.9 & $190 \pm 4$ & $1.136 \pm 0.024$ \\
\hline \multirow[t]{2}{*}{ Fertile } & MB25 & $\mathrm{U}-238 \quad(99.8)$ & -8.283 & $-7.63 \pm 0.32$ & $1.086 \pm 0.046$ \\
\hline & PU240-2D & $\mathrm{PuO}_{2}(\mathrm{Pu}-240 \quad 80.7)$ & +19.32 & $17.1 \pm 0.3$ & $1.030 \pm 0.020$ \\
\hline Poison & $\mathrm{B}-7$ & B-10 (87.1) & -1948 & $-1948 \pm 40$ & $1.010 \pm 0.021$ \\
\hline \multirow{2}{*}{ Structural } & MN-1 & $\operatorname{Mn}(1.00 .0)$ & -13.360 & $-7.27 \pm 0.63$ & $1.838^{\circ} \pm 0.159$ \\
\hline & MB19 & $\begin{array}{l}\text { Stee1 }(100.0) \\
\text { (type } 304)\end{array}$ & -5.688 & $-4.68 \pm 0.07$ & $1.215 \pm 0.020$ \\
\hline \multirow[t]{3}{*}{ Moderator } & $\mathrm{CH} 2(\bar{I})$ & $\mathrm{CH}_{2}$ foam $(100.0)$ & -222 & +8.8 & -25 \\
\hline & POLY-1 & $\mathrm{CH}_{2}$ solid $(100.0)$ & -222 & $+155 \pm 4$ & -1.43 \\
\hline & $\mathrm{H} 20-1 \mathrm{~A}$ & $\mathrm{H}_{2} \mathrm{O}$ in capsule $(100.0)$ & -169 & $+108 \pm 3$ & -1.56 \\
\hline
\end{tabular}

(a) As solid or annular cylinders of up to $2.1 \mathrm{~cm}$ diameter and $5.5 \mathrm{~cm}$ length.

(b) From Ref. 2 .

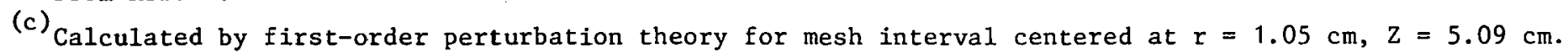

(d) Measured within traverse guide tube, offset axially by $4.4 \mathrm{~cm}$ from core midplane, at center of central. matrix tube. 


\subsection{MATERIAL-WORTH RADIAL PROFILES}

For seven of the samples listed in Table 5-2, the worth coefficients were also determined at several positions along the traverse guide tube, which installed through the row -23 drawers about $4 \mathrm{~cm}(1.56 \mathrm{in}$.) from the midplane in one half of the reactor. Radial worth profiles (in the horizontal or X-direction) were thus obtained for the core principal constituents (plutonium, U-235, U-238, and stee1), for poison materials (B-10 and L-6), and for polyethylene. Calculated worth profiles for these same materials were dertved using PERT and the reference RZ-2DB fluxes as used for the central values; however, additional material cross sections were employed as representative of the other core zone and blanket environments through which the scans were made.

The calculated radial worth profiles are plotted in comparison with experimental points in Figs. 5-1 through 5-7, respectively, for the above cited material samples. However, for the comparisons here, the actual calculated values (in inhours/kilograms) have been renormalized to agree with the measured worth at core center (i.e., the calculated worths versus radius were divided by the $C / E$ value for the sample worth at corc center listed in Table 5-2). For the plutonium and enriched-uranium worths, profiled in Figs. 5-1 and 5-2, excellent agreement is seen between the normalized calculations and the measured radial scans. The same is true for the highly absorbing materials $B-10$ and Li-6 (Figs. 5-5 and 5-6).

However, calculated profiles do not agree well with measured data where the net sample worths are not dominated by either a fission component or strong absorption cross section. Thus, for the U-238 radial worth scan, shown in Fig. 5-3, the normalized calculated curve becomes significantly more negative, in absolute difference, proceeding radially out through the core; here the overall worth is the net of relatively similar contributions from fission, capture, and leakage. Just as discrepant is the steel-worth profile in Fig. 5-4, where the worth components are a blend of downscatter, absorption, and leakage effects. 


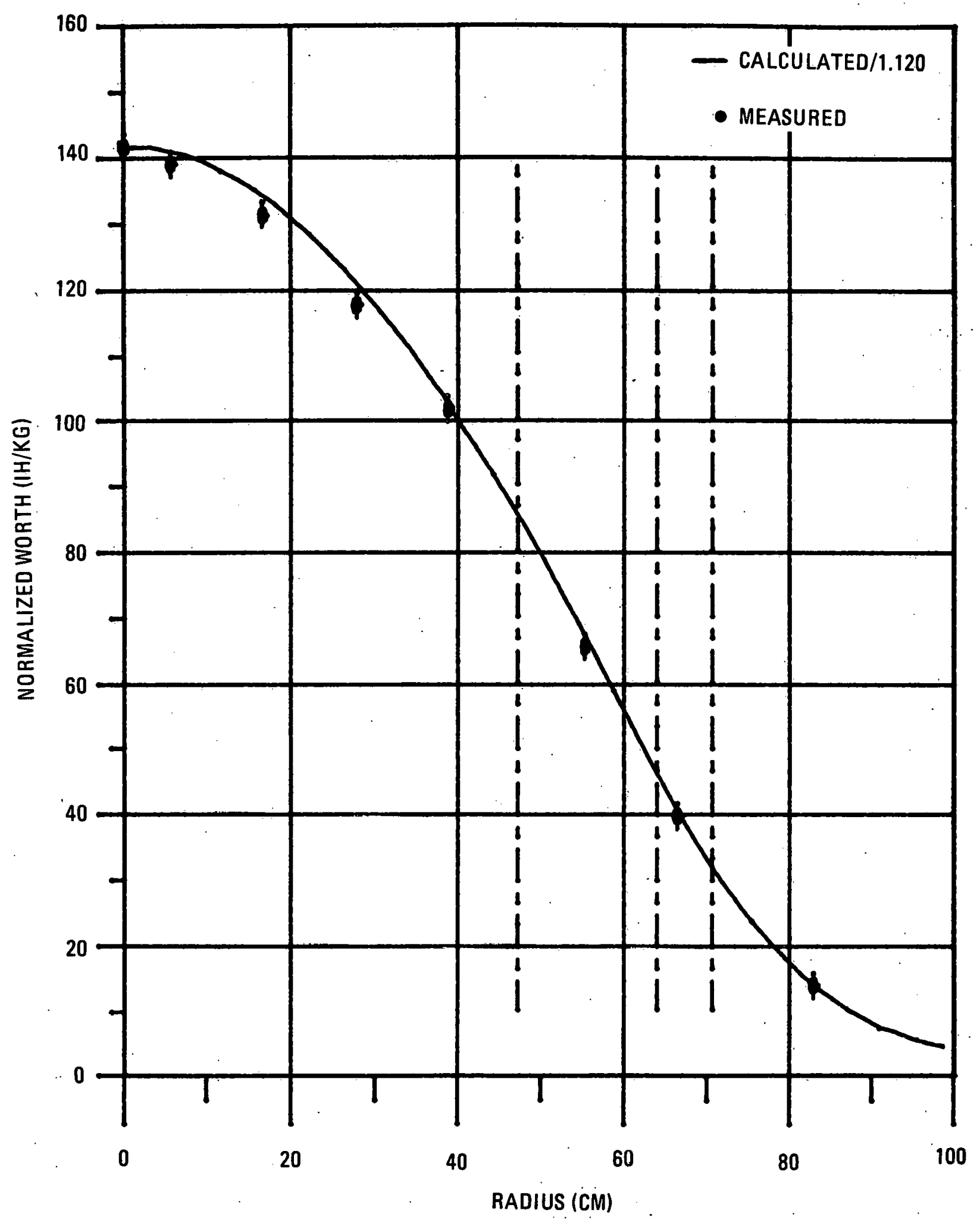

Fig. 5-1. Radial worth traverse for Pu-239. 


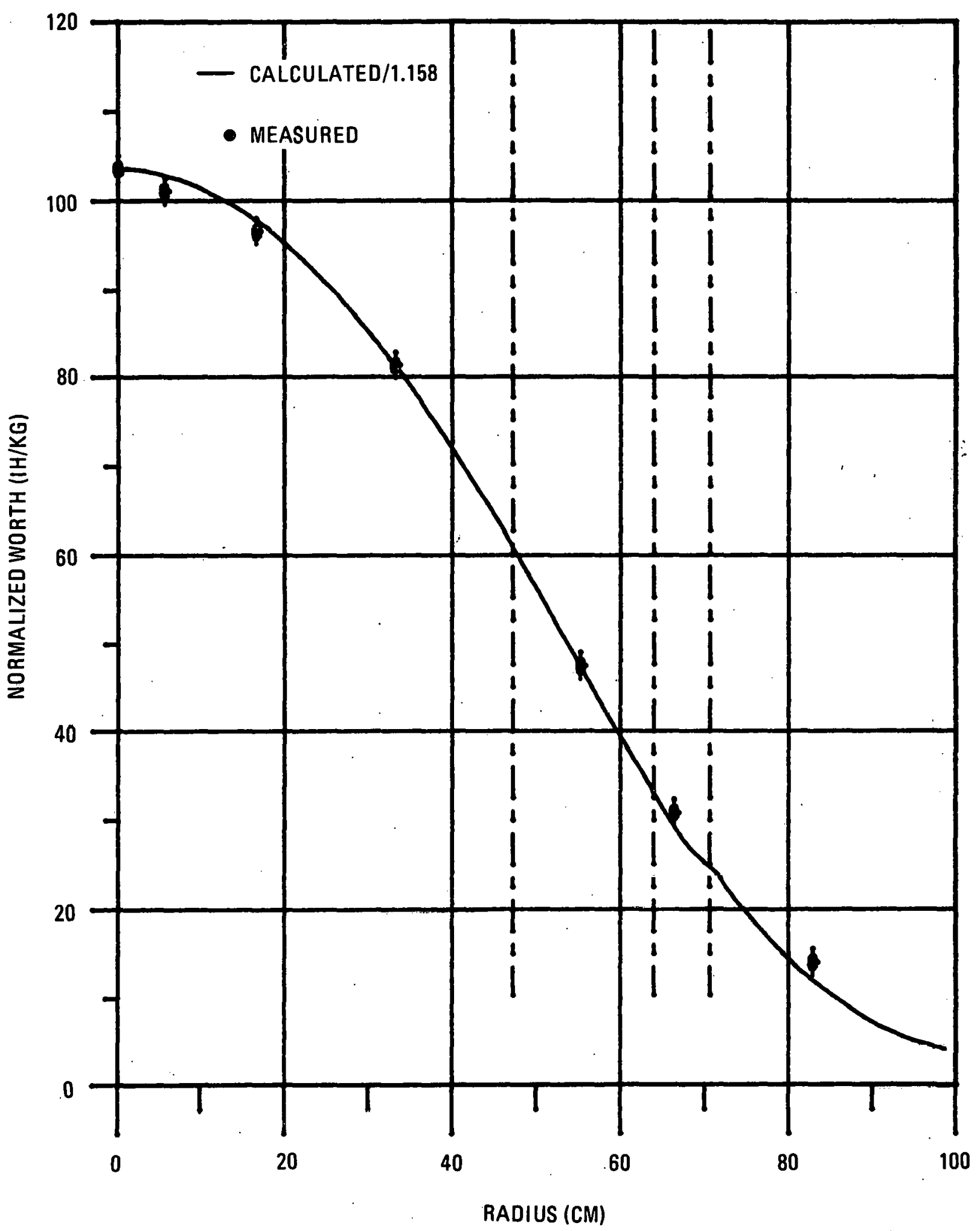

F1g. 5-2. Radial worth traverse for enriched uranium 


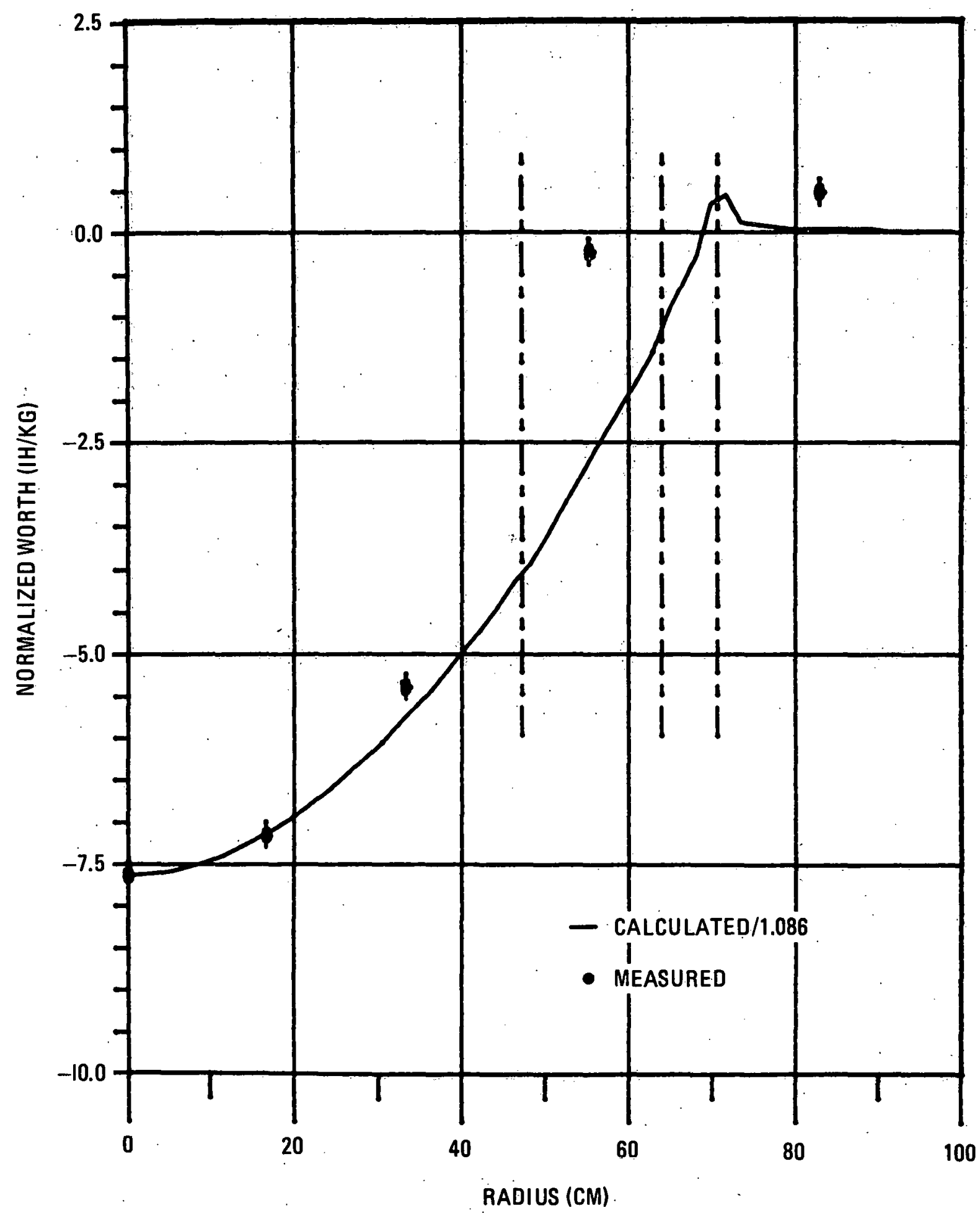

Fig. 5-3. Radial worth traverse for depleted uranium 


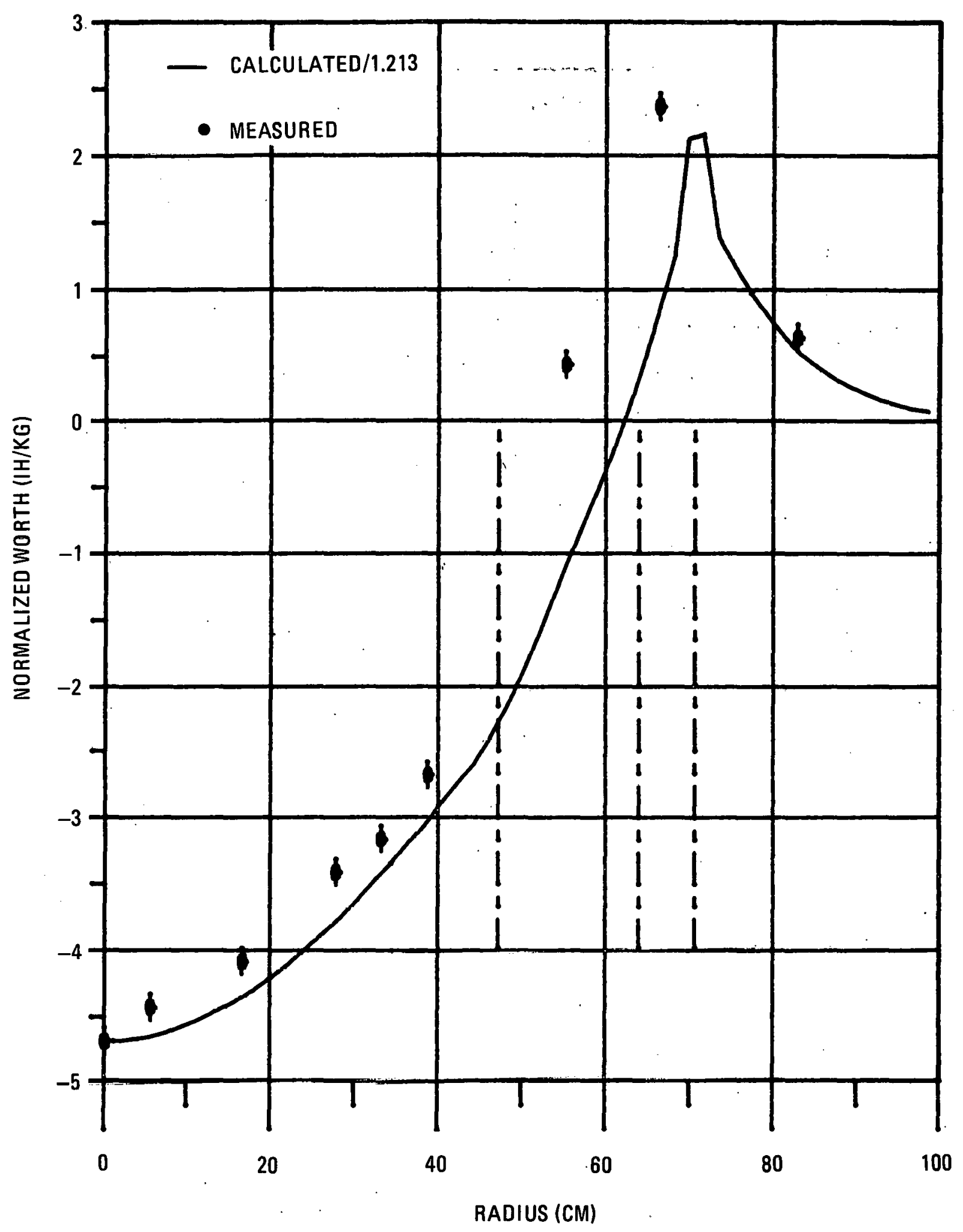

F1g. 5-4. Radial worth traverse for stainless. steel 


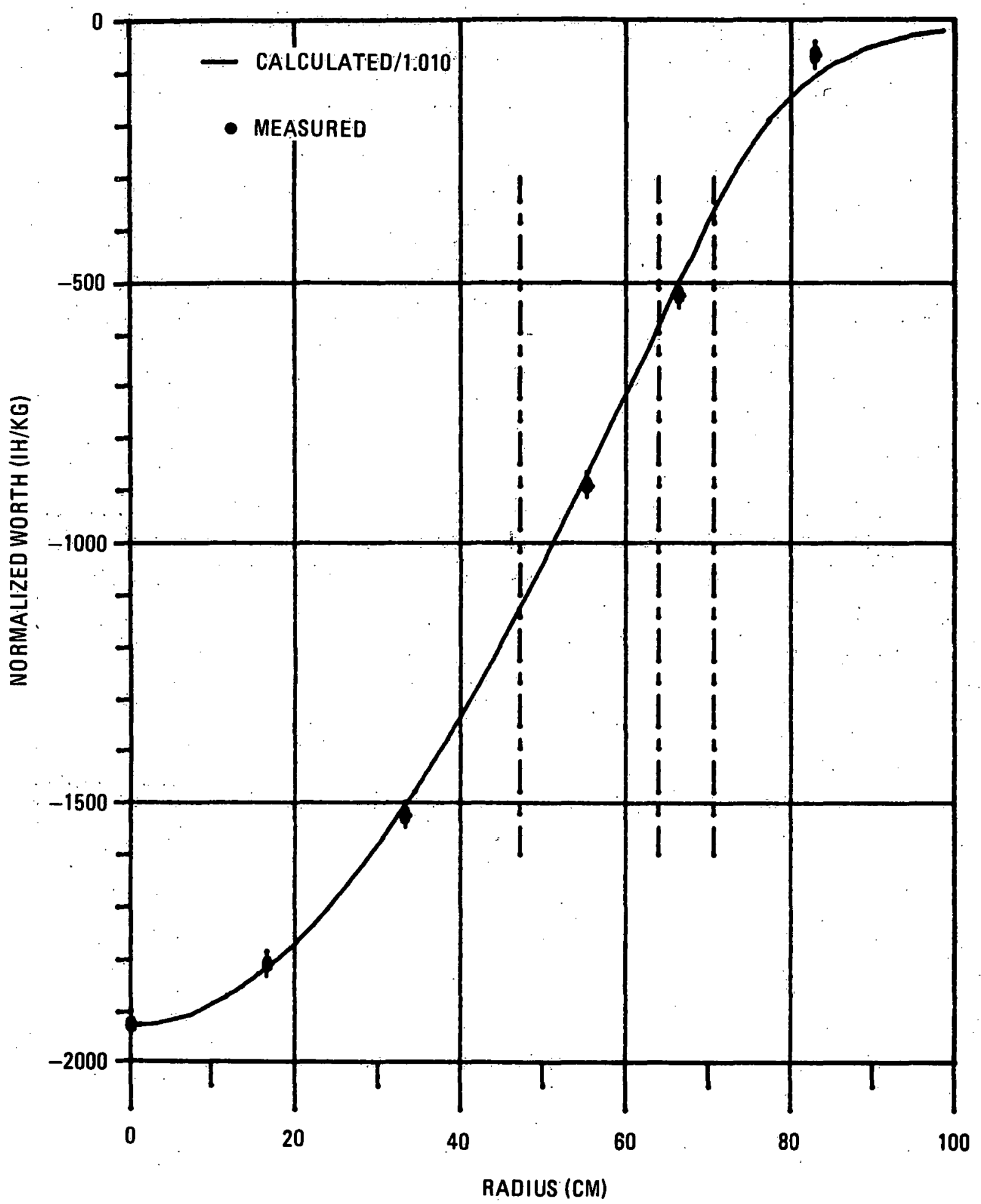

F1g. 5-5. Radial worth traverse for B-10 


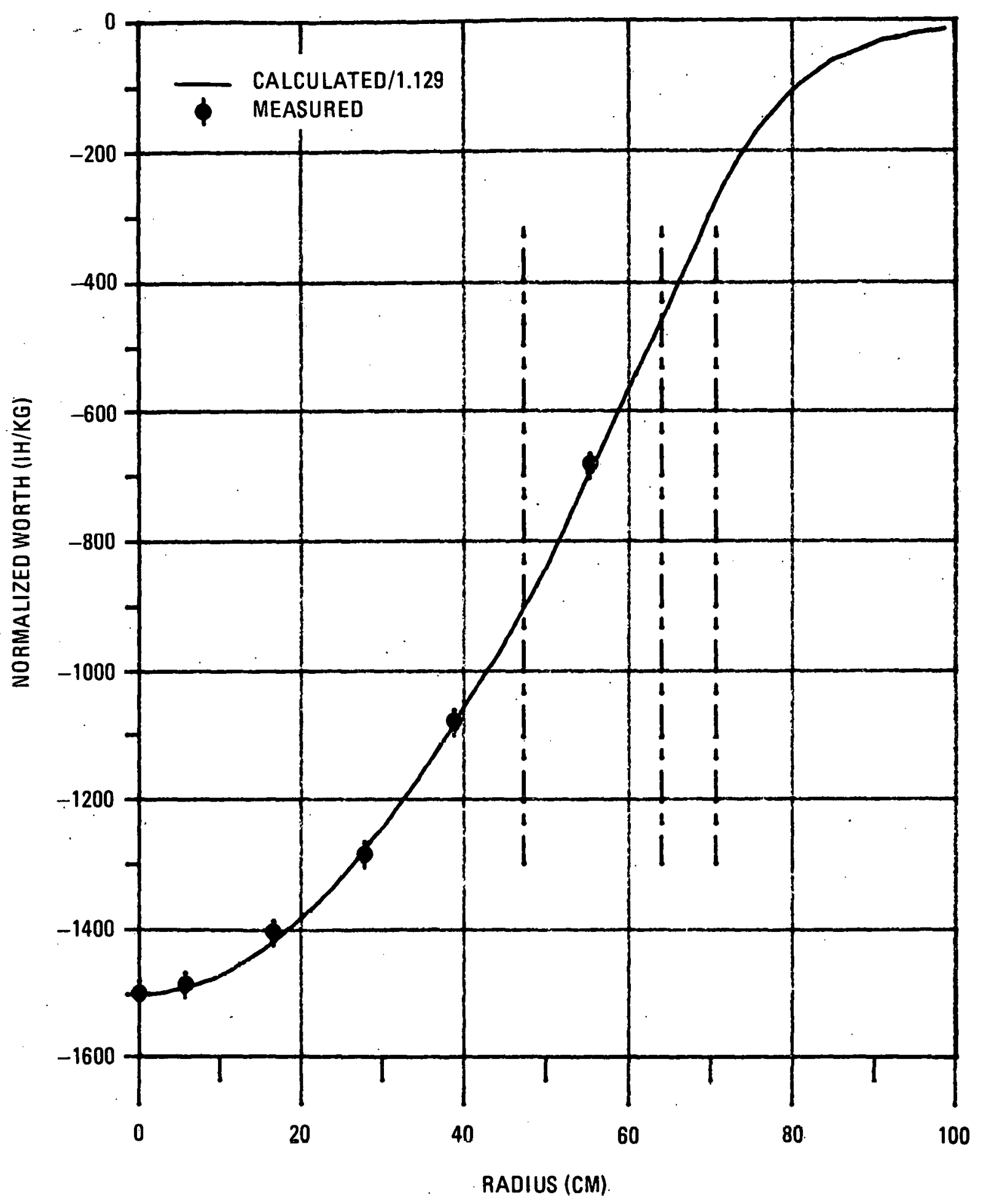

Fig. 5-6. Radial worth traverse for L1-6 


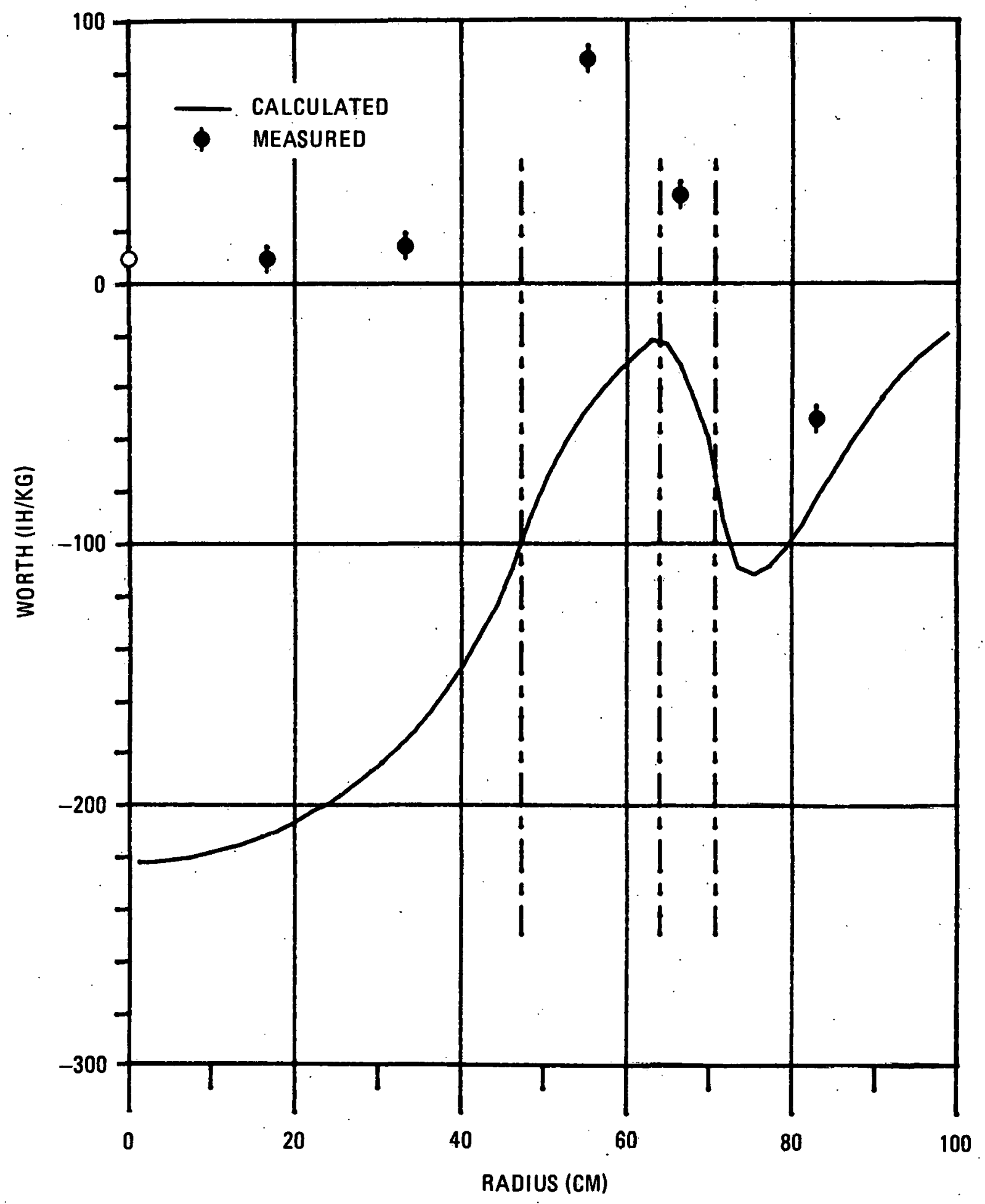

Fig. 5-7. Radial worth traverse for $\mathrm{CH}_{2}$ foam 
Calculated and measured worths for polyethylene are plotted in Fig. 5-7; here no renormalization was done for the calculated curve, considering the invalidity of the first-order perturbation evaluation for this material. This graph serves only to illustrate the relative impact of the positive leakage component of the $\mathrm{CH}_{2}$ worth in the core outer region, which then becomes overwhelmed by the negative downscatter effect in the blanket.

\subsection{APPARENT-WORTH PROFILE FOR CF-252 NEUTRON SOURCE}

As part of the experimental determination of isotopic absorption-tofission ratios $(1+\alpha)$, radial traverses were made at two different power levels with a calibrated Cf-252 spontaneous-fission neutron source in the same guide tube as for sample worth traverses. The procedure yielded a profile for this apparent worth of the source (with respect to a specified power level). The normalized source-worth scan is compared in Fig. 5-8 with a normalized profile from the PERT run of the calculated-fission-source importance, i.e., the point-wise relative worth of fission neutrons

$$
\left[\sum_{i=1}^{N G} x_{i} \phi_{i}^{*}(r)\right]
$$

As seen in Fig. 5-8, the calculated and measured data are in excellent agreement, considering the $\mathrm{R}-\mathrm{Z}$ mode of the calculation and the reactangulargeometry environment in which the experiments were conducted.

\subsection{CALCULATIONAL BIASES FOR MATERIAL WORTHS}

In an attempt to delineate possible sources of the calculational discrepancies for material worths at various reactor locations, Tables 5-3 through 5-6 were constructed to show the $C$ to $E$ ratios ( $C / E$ ) and the $C$ minus $\mathrm{E}$ (C-E) variations with radius for the principal core materials $\mathrm{Pu}-239$, $\mathrm{U}-238$, steel, and $\mathrm{B}-10$. The calculated reactivity coefficients 1 isted in these tables include the breakdowns of contributing reaction worths from fission-produced neutrons $\left(\nu \sum_{f}\right)$, absorption, leakage, and downscatter. 


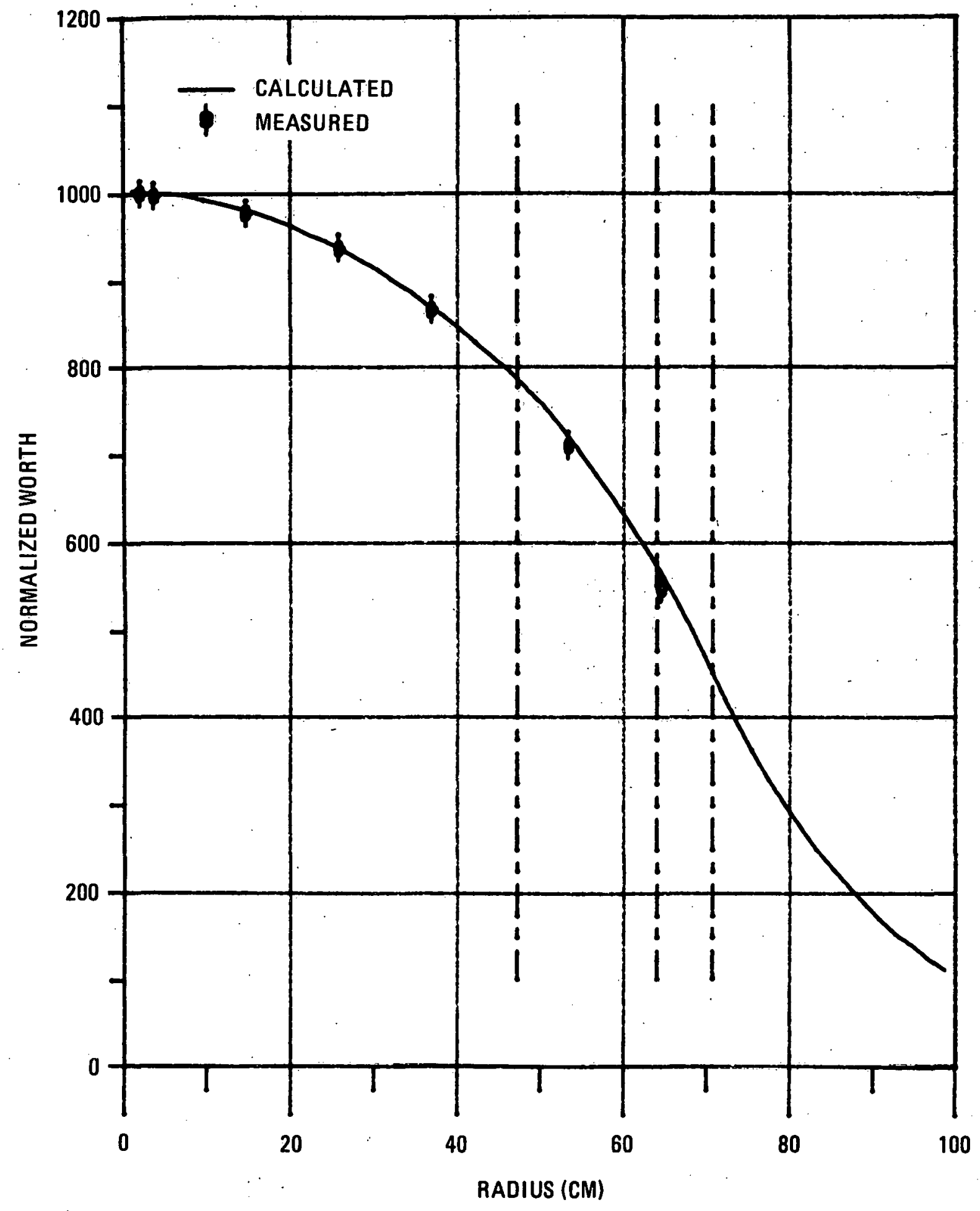

Fig. 5-8. Radial worth traverse for Cf-252 source 
TABLE 5-3

RADIAL WORTH TFAVERSE FOR Pu-239 SAMPLE AT MIDPLANE OF PHASE III ASSEMBLY

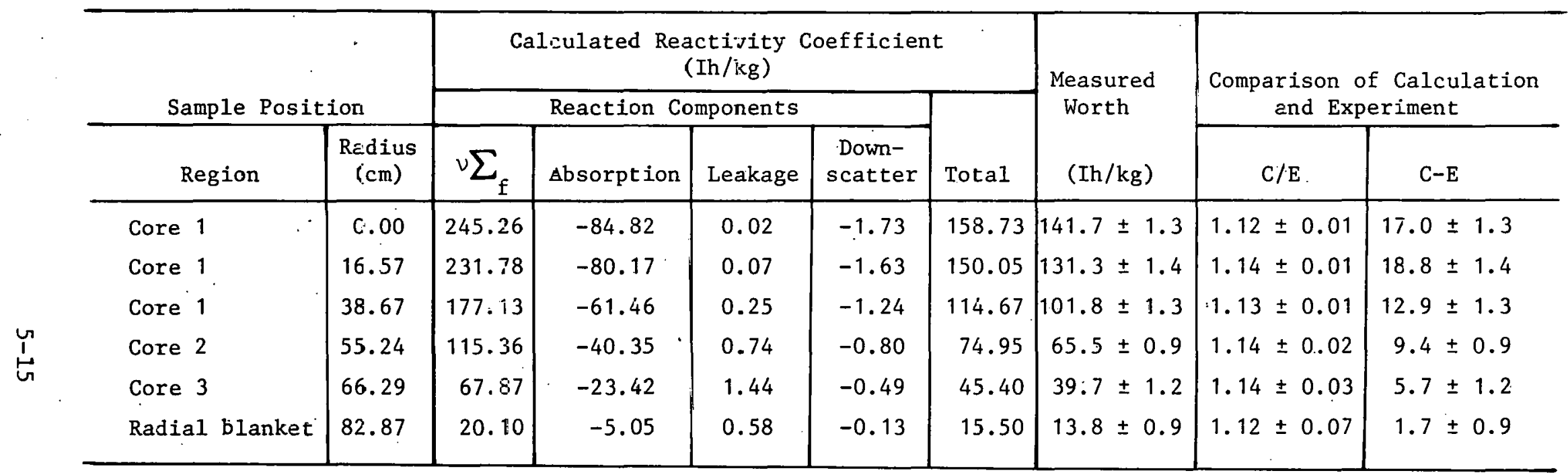


TABLE 5-4

RADIAL WORTH TRAVERSE FOR DEPLETED URANIUM SAMPLE AT MIDPLANE OF PHASE III GCFR ASSEMBLY

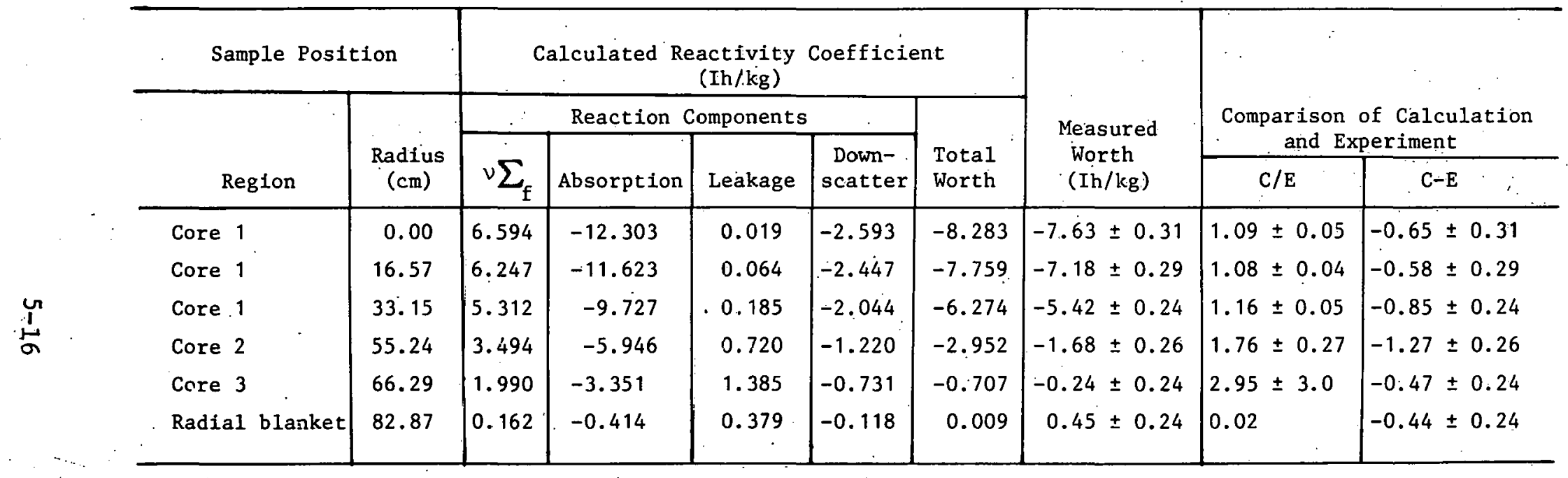


TABLE 5-5

RADIAL WORTH TRAVERSE FOR STEEL SAMPLE AT MIDPLANE OF PHASE III GCFR ASSEMBLY

\begin{tabular}{|c|c|c|c|c|c|c|c|c|}
\hline \multicolumn{2}{|c|}{ Sample Position } & \multicolumn{4}{|c|}{$\begin{array}{c}\text { Calculated Reactivity Coefficient } \\
(\mathrm{Ih} / \mathrm{kg})\end{array}$} & \multirow{2}{*}{$\begin{array}{l}\text { Measured } \\
\text { Worth } \\
\text { (Ih/kg) }\end{array}$} & \multirow{2}{*}{\multicolumn{2}{|c|}{$\begin{array}{l}\text { Comparison of Calculation } \\
\text { and Experiment }\end{array}$}} \\
\hline Region & $\begin{array}{c}\text { Radius } \\
(\mathrm{cm})\end{array}$ & \multicolumn{3}{|c|}{ Reaction Compcinents } & $\begin{array}{l}\text { Total } \\
\text { Worth }\end{array}$ & & & \\
\hline Core 1 & 0.00 & -2.087 & 0.037 & -3.638 & -5.688 & $-4.69 \pm 0.07$ & $1.21 \pm 0.02$ & $-1.00 \pm 0.07$ \\
\hline Core 2 & 16.57 & -1.971 & 0.125 & -3.439 & -5.285 & $-4.10 \pm 0.11$ & $1.29 \pm 0.04$ & $-1.10 \pm 0.11$ \\
\hline Core 2 & 55.24 & -0.982 & 1.338 & -1.689 & -1.333 & $0.41 \pm 0.07$ & $-3.3 \pm 0.6$ & $-.174 \pm 0.07$ \\
\hline Core 3 & 66.29 & -0.577 & 2.607 & -1.043 & 0.987 & $2.36 \pm 0.07$ & $0.42 \pm 0.01$ & $-1.37 \pm 0.07$ \\
\hline Radial blanket & 82.87 & -0.112 & 1.096 & -0.34 .5 & 0.639 & $0.62 \pm 0.07$ & $1.03 \pm 0.11$ & $0.02 \pm 0.07$ \\
\hline
\end{tabular}


TABLE $\cdot 5-6$

RADIAL WORTH TRAVERSE FOR B-10 SAMPLE AT MIDPLANE OF PHASE III GCFR. ASSEMBLY

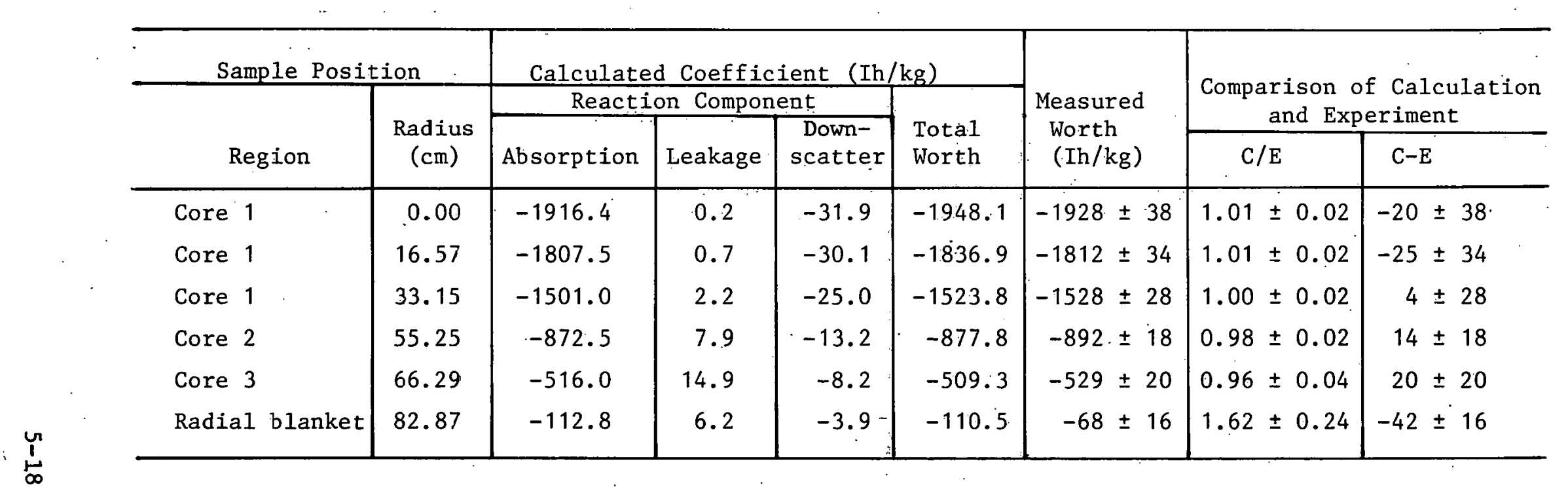


The Pu-239, worth data in Table 5-3 show that the production term, less the associated absorption worth, is the predominant component and that the Jeakage contribution is never significant. The data also show that the $\mathrm{C} / \mathrm{E}$ is constant with radial location; thus, the C-E term varies in proportion to the total coefficient.

For the B-10 worths (Table 5-6), the calculated (unnormalized) values agree within experimental errors with the measured coefficients throughout the core. However, a $1.62 \mathrm{C} / \mathrm{E}$ value is observed for the measurcment in the radial blanket, which is puzzling. The 10-group averaging might be deficient for the $i-10$ cross section in the blanket GGCS case; however, a similar C/E vas obtained by ANL using 28-group analysis. Similar to the plutonium-worth data, the leakage component calculated for the B-10 worth is never of importance, reaching only $6 \%$ of the total for the blanket location.

Table 5-4 breaks down the U-238 sample worth versus radius according to reaction type. The negative absorption terms are a relatively constant stant factor of about 1.5 times the positive fission-source contributions throughout the core. The downscatter component varies approximately as the absorption term, a not unreasonable expectation. Because of these contradicting components, the leakage worth can become a significant factor of the net sample effcct. The highly variable $\mathrm{C} / \mathrm{E}$ for this material with radius probably reflects significant discrepancies in predicting the leakage componenl. However, it is difficult to imagine how the transport cross sections or the calculated flux gradients could be off by the factors of about 2 required to explain the observed C-E discrepancics.

A similar situation exists with the steel worth-scan date in Table 5-5; here the leakage term rapidly becomes comparable to the absorption and downscaller components, but of opposite sign. The resulting $C / E$ values vary considerably, and the C-E value becomes comparable to the net worth. Again, it does not seem possible for transport cross section errors or fluxgradient errors to be large enough to explain the discrepancies. 
This brief survey suggests some possible flaw in the analytical interpretation of the traverse-sample worth measurements. The more likely explanation is that the experimental technique introduces significant. perturbations of the reactor environment to invalidate the assumptions inherent to first-order perturbation theory. Specifically, the traverse guide tube appears to introduce a neutron streaming channel. Thus, in the regions of steep flux gradients, the sample placements have an added positive vorth contribution from the effect of interrupting the streaming. This consideration could explain many of the C-E anomalies noted in Tables 5-4 through 5-6 for the outer radial locations. 


\section{REACTION RATE RATIOS}

\subsection{FOIL ACTIVATIONS FOR FUEL REACTIONS}

Measurements of the relative fission rates in the isotopes $U-235$, $\mathrm{U}-238$, and $\mathrm{Pu}-239$ and the relative capture rate in U-238 were made at . several locations in the core and blankets of the Phase III assembly. The objectives here were to quantify the per-atom ratios of these isotopic reaction rates as they would occur at power within the fuel and fertile materials throughout the core and blanket of the corresponding-design power reactor. The derived $\mathrm{U}-238$-capture to $\mathrm{Pu}-239$-fission ratios, on a regionaveraged basis, are the principal factors for the prediction of the reactor breeding performance.

Fstablishing the in-plate-fuel reaction rates requires a foilactivation technique wherein thin samples of the pluconium and uranium materials are placed adjacent to and within the columns of $\mathrm{Pu}-\mathrm{U}-\mathrm{Mo}, \mathrm{U}_{3} \mathrm{O}_{8}$, and depleted uranium. Adequate assessments of cell-averaged rates required several placements of foils per drawer at each of the locations studies, as dictated by the complexity of the ZPR drawer loadings. The fission rates are evaluated after an irradiation by measuring fission-product activity and the $\mathrm{U}-238$ capture rate determined from Np-239-decay activity.

Tables 6-1 through 6-5 compare the measured and calculated cellaveraged values of the ratios U-235 fission/Pu-239 fission (F5/F9)*, U-238 fission/Pu-239 fission (F8/F9), U-238 capture/Pu-239 fission (C8/F9), U-238

\footnotetext{
*In the tables and in the following text, the abbreviations below are used:

$F=$ fission.

$\mathrm{C}=$ capture.

$5=\mathrm{U}-235$.

$8=\mathrm{U}-238$.

$9=\mathrm{Pu}-239$.
} 
TABLE 6-1

MEASURED AND CALCULATED CELL AVERAGE PER-ATOM RATIOS. OF U-235 FISSION TO Pu-239 FISSION IN PHASE III GCFR ASSEMBLY

\begin{tabular}{|c|c|c|c|c|c|c|c|}
\hline \multicolumn{5}{|c|}{ Experimental Details } & \multirow{2}{*}{\multicolumn{2}{|c|}{$\begin{array}{c}\text { Calculated } \\
\text { Ratios }\end{array}$}} & \multirow{4}{*}{$\begin{array}{c}\text { Calculation } \\
\text { Bias, } \\
\text { C/E } \\
( \pm 0.018)\end{array}$} \\
\hline \multirow{3}{*}{$\begin{array}{l}\text { Reactor } \\
\text { Region }\end{array}$} & \multirow{3}{*}{$\begin{array}{l}\text { Matrix } \\
\text { Location } \\
\text { Row/Co1. }\end{array}$} & \multirow{2}{*}{\multicolumn{2}{|c|}{$\begin{array}{c}\text { Cell Center } \\
\text { Position (cm) }\end{array}$}} & \multirow{3}{*}{$\begin{array}{l}\text { Measured } \\
\text { F5/F9 Ratio }\end{array}$} & & & \\
\hline & & & & & \multirow{2}{*}{$\begin{array}{r}\mathrm{RZ} \\
2 \mathrm{DB}\end{array}$} & \multirow{2}{*}{$\begin{array}{r}\mathrm{XY} \\
2 \mathrm{DB}\end{array}$} & \\
\hline & & Radial & Axial & & & & \\
\hline Core 1 & $23 / 23$ & 0.0 & 1.5 & $1.044 \pm 0.016$ & 1.0278 & 1.0277 & 0.984 \\
\hline Core 1 & $15 / 23$ & 44.2 & 1.6 & $1.032 \pm 0.017$ & 1.0104 & 1.0118 & 0.980 \\
\hline Core 1 & $23 / 23$ & 0.0 & 55.9 & $1.090 \pm 0.017$ & 1.0742 & -- & 0.986 \\
\hline Core 2 & $.13 / 23$ & 55.2 & 1.6 & $1.021 \pm 0.018$ & 1.0036 & 1.0077 & 0.987 \\
\hline Core 2 & $23 / 33$ & 51.3 & 1.6 & $1.017 \pm 0.018$ & 1.0053 & 1.0057 & 0.989 \\
\hline Core 3 & $11 / 23$ & 66.3 & 1.6 & $1.060 \pm 0.018$ & 1.0167 & 1.0270 & 0.969 \\
\hline
\end{tabular}


TABLE 6-2

MEASURED AND CALCLLATED CELL AVERAGE PER-ATOM RATIOS OF U-238 FISSION TO Pu-239 FISSION IN PHASE III GCFR ASSEMBLY

\begin{tabular}{|c|c|c|c|c|c|c|c|}
\hline \multirow{4}{*}{$\begin{array}{l}\text { Reactor } \\
\text { Region }\end{array}$} & \multicolumn{3}{|c|}{ Experimental Details } & & \multirow{2}{*}{\multicolumn{2}{|c|}{$\begin{array}{l}\text { Calculated F8/F9 } \\
:: \text { Ratios }\end{array}$}} & \multirow{4}{*}{$\begin{array}{c}\text { Calculationa } 1 \\
\text { Bias, } \\
\text { C/E } \\
( \pm 0.018)\end{array}$} \\
\hline & \multirow{3}{*}{$\begin{array}{l}\text { Matrix } \\
\text { Location } \\
\text { Row/Col. }\end{array}$} & \multirow{2}{*}{\multicolumn{2}{|c|}{$\begin{array}{c}\text { Cell Center } \\
\text { Position (cm) }\end{array}$}} & \multirow{3}{*}{$\begin{array}{l}\text { Measured } \\
\text { F8/F9 Ratio }\end{array}$} & & & \\
\hline & & & & & $\mathrm{RZ}$ & $X Y$ & \\
\hline & & Radia1 & Axial & & 2DB & $2 \mathrm{DB}$ & \\
\hline Core 1 & $23 / 23$ & 0.0 & 1.6 & $0.02740 \pm 0.00044$ & 0.02636 & 0.02637 & 0.962 \\
\hline Core 1 & $15 / 23$ & 44.2 & 1.6 & $0.02806 \pm 0.00047$ & 0.02807 & 0.02799 & 0.997 \\
\hline Core 1 & $23 / 23$ & 0.0 & 55.9 & $0.02375 \pm 0.00040$ & 0.02246 & -- & 0.946 \\
\hline Core 2 & $13 / 23$ & 55.2 & 1.6 & $0.03140 \pm 0.00057$ & 0.03038 & 0.03008 & 0.958 \\
\hline Core 2 & $23 / 33$ & 51.5 & 1.6 & $0.03200 \pm 0.00059$ & 0.02999 & 0.02990 & 0.934 \\
\hline Core 3 & $11 / 23$ & $66 . \pm$ & 1.6 & $0.03153 \pm 0.00056$ & 0.02979 & 0.02834 & 0.899 \\
\hline
\end{tabular}


TABLE 6-3

MEASURED AND CALCULATED CELL AVERAGE PER-ATOM RATIOS OF U-238 CAPTURE TO PU-239 FISSION IN PHASE III GCFR ASSEMBLY

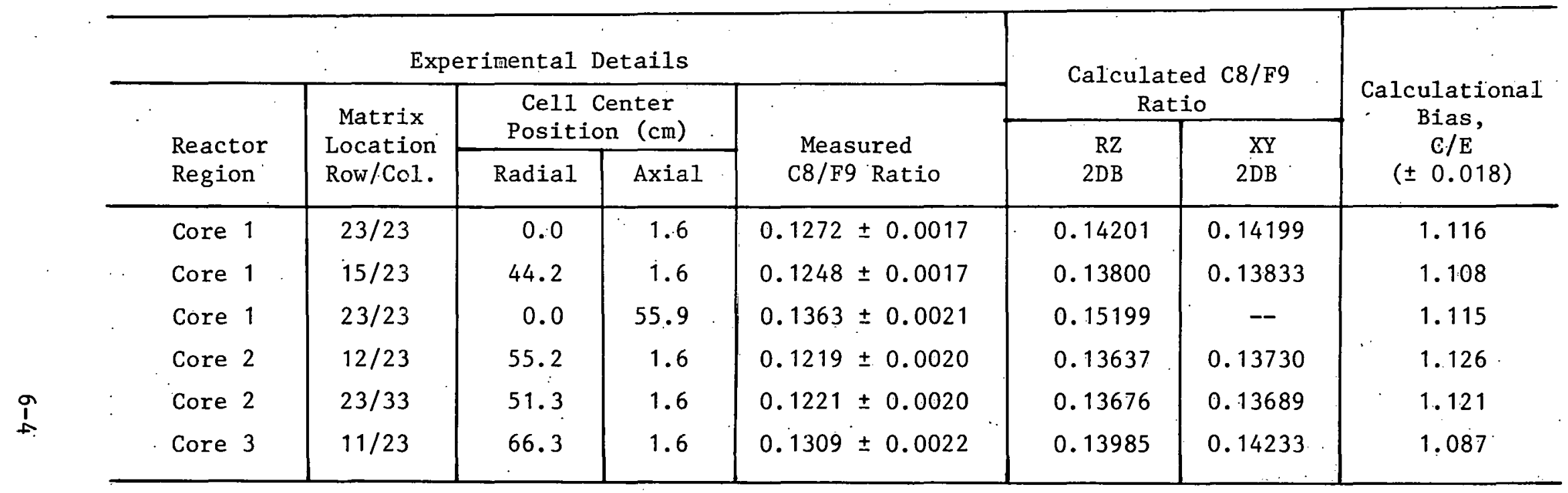


TABLE $6 \div 4$

MEASURED AND CALCULATED CELL AVERAGE PER-ATOM RATIOS

OF U-238 FISSION TO U-235 FISSION IN PHASE III GCFR ASSEMBLY

\begin{tabular}{|c|c|c|c|c|c|c|c|}
\hline \multicolumn{5}{|c|}{ Experimental Details } & \multirow{2}{*}{\multicolumn{2}{|c|}{$\begin{array}{c}\text { Calculated F8/F5 } \\
\text { Ratios }\end{array}$}} & \multirow{4}{*}{$\begin{array}{c}\text { Calculational } \\
\text { Bias } \\
\text { C/E } \\
( \pm 0.019)\end{array}$} \\
\hline \multirow{3}{*}{$\begin{array}{l}\text { Reactor } \\
\text { Region }\end{array}$} & \multirow{3}{*}{$\begin{array}{l}\text { Matrix } \\
\text { Location } \\
\text { Row/Col. }\end{array}$} & \multirow{2}{*}{\multicolumn{2}{|c|}{$\begin{array}{l}\text { De11 Center } \\
\text { Position }(\mathrm{cm}) \\
\end{array}$}} & \multirow{3}{*}{$\begin{array}{l}\text { Measured } \\
\text { F8/F5 Ratio }\end{array}$} & & & \\
\hline & & & & & $\mathrm{RZ}$ & $X Y$ & \\
\hline & & Radial & Axial & & $2 \mathrm{DB}$ & $2 \mathrm{DB}$ & \\
\hline Core 1 & $23 / 23$ & 0.0 & 1.6 & $0.02625 \pm 0.00044$ & 0.02565 & 0.02566 & 0.978 \\
\hline Core 1 & $15 / 23$ & 44.2 & 1.6 & $0.02719 \pm 0.00047$ & 0.02779 & 0.02766 & 1.017 \\
\hline Core 1 & $23 / 23$ & 0.0 & 55.9 & $0.02179 \pm 0.00040$ & 0.02091 & -- & 0.959 \\
\hline Core 2 & $13 / 23$ & 55.2 & 1.6 & $0.03075 \pm 0.00057$ & 0.03027 & 0.02985 & 0.971 \\
\hline Core 2 & $23 / 33$ & 51.3 & 1.6 & $0.03147 \pm 0.00059$ & 0.02983 & 0.02973 & 0.945 \\
\hline Core 3 & $11 / 23$ & 6.6 .3 & 1.6 & $0.02975 \pm 0.00056$ & 0.02930 & 0.02760 & 0.928 \\
\hline Axial blanket & $23 / 23$ & 0.0 & 62.7 & $0.01382 \pm 0.00025$ & 0.01382 & -- & 1.000 \\
\hline Axial blanket & $23 / 23$ & 0.0 & 86.4 & $0.00428 \pm 0.00011$ & 0.003562 & -- & 0.832 \\
\hline Radial blanket & $10 / 23$ & 71.8 & 1.6 & $0.01698 \pm 0.00030$ & 0.01888 & 0.01687 & 0.994 \\
\hline Radial blanket & $6 / 23$ & 93.9 & 1.6 & $0.00413 \pm 0.00010$ & 0.004076 & 0.003628 & 0.878 \\
\hline
\end{tabular}


TABLE 6-5

MEASURED AND CALCULATED CELL AVERAGE PER-ATOM RATIOS OF U-238 CAPTURE TO U-235 FISSION IN PHASE III GCFR ASSEMBLY

\begin{tabular}{|c|c|c|c|c|c|c|c|}
\hline \multicolumn{5}{|c|}{ Experimental Details } & \multirow{2}{*}{\multicolumn{2}{|c|}{$\begin{array}{c}\text { Calculated C8./F5 } \\
\text { Ratios }\end{array}$}} & \multirow{4}{*}{$\begin{array}{c}\text { Calculational } \\
\text { Bias, } \\
\text { C/E }\end{array}$} \\
\hline \multirow{3}{*}{$\begin{array}{l}\text { Reactor } \\
\text { Region }\end{array}$} & \multirow{3}{*}{$\begin{array}{l}\text { Matrix } \\
\text { Location } \\
\text { Row/Col. }\end{array}$} & \multirow{2}{*}{\multicolumn{2}{|c|}{$\begin{array}{c}\text { Cell Center } \\
\text { Position }(\mathrm{cm})\end{array}$}} & \multirow{3}{*}{$\begin{array}{l}\text { Measured } \\
\text { C8/F5 Ratio }\end{array}$} & & & \\
\hline & & & & & $\mathrm{RZ}$ & $X Y$ & \\
\hline & & Radial & Axial & & $2 \mathrm{DB}$ & $2 \mathrm{DB}$ & \\
\hline Core 1 & $23 / 23$ & 0.0 & 1.6 & $0.1218 \pm 0.0017$ & 0.13818 & 0.13816 & 1.134 \\
\hline Core 1 & $15 / 23$ & 44.2 & 1.6 & $0.1209 \pm 0.0017$ & 0.136 .58 & 0.13672 & 1.130 \\
\hline Core 1 & $23 / 23$ & 0.0 & 55.9 & $0.1250 \pm 0.0021$ & 0.14149 & -- & 1.132 \\
\hline Core 2 & $12 / 23$ & 55.2 & 1.6 & $0.1194 \pm 0.0020$ & 0.13588 & 0.13625 & 1.141 \\
\hline Core 2 & $23 / 33$ & $51 \cdot 3$ & 1.6 & $0.1201 \pm 0.0020$ & 0.13604 & 0.13611 & 1.134 \\
\hline Core 3 & $11 / 23$ & 66.3 & 1.6 & $0.1235 \pm 0.0022$ & 0.13754 & 0.13859 & 1.123 \\
\hline Axial blanket & $23 / 23$ & 0.0 & 62.7 & $0.1243 \pm 0.0016$ & 0.13818 & -- & 1.112 \\
\hline Axial blanket & $23 / 23$ & 0.0 & 86.4 & $0.1223 \pm 0.0017$ & 0.13090 & -- & 1.070 \\
\hline Radial blanket & $10 / 23$ & 71.8 & 1.6 & $0.1228 \pm 0.0016$ & 0.13512 & 0.13571 & 1.105 \\
\hline Radial blanket & $6 / 23$ & 93.9 & 1.6 & $0.1145 \pm 0.0016$ & 0.13007 & 0.12702 & 1. 109 \\
\hline
\end{tabular}


fission/U-235 fission (F8/F5), and U-238 capture/U-235 fission (C8/F5). The calculated ratios were derived via a PERT code option which uses the 2DBinput fuel cross sections and the 2DB-output 10-group flux distributions. The ratios were calculated using both the $\mathrm{RZ}$ and $\mathrm{XY}-2 \mathrm{DB}$ fluxes for the reference Phase III configuration. The last column in each of the tables expresses the calculational bias $\mathrm{C} / \mathrm{E}$ derived using the $\mathrm{XY}-2 \mathrm{DB}$ results for the activations near the midplane and the $\mathrm{RZ}$ results for measurements along the core axis.

\subsubsection{U-235/Pu-239 Fission Ratio}

Table 6-1 shows that the ratio of U-235 fission to $\mathrm{Pu}-239$ fission is slightly underpredicted $(-1.5 \%)$ in core zones 1 and 2 , with the discrepancy increasing to $-4 \%$ in core zone 3 . This fission ratio is not a very sensitive gauge of the accuracy of the calculated spectrum; thus, the $\mathrm{C} / \mathrm{E}$ discrepancies probably result from errors in the $\mathrm{Pu}-239$ in-plate fission cross section either in the basic ENDF/B-4 data or in heterogeneity-effect processing in the multigroup preparations.

\subsubsection{U-238/Pu-239 Fissiun Rat10}

Table 6-2 shows the U-238/Pu-239 fission ratio (F8/F9), a highly sensitive gauge of the upper end of the neutron-energy spectrum, but also dependent on the flux-advantage factors for the fuel plates in the high-energy groups. Again, the $\mathrm{C} / \mathrm{E}$ values are less than unity by from $0.3 \%$ to $10 \%$. The $-10 \%$ discrepancy for core zone 3 suggests that the calculated high-energy flux advantage factors for the zone $3 \mathrm{Pu}-\mathrm{U}-\mathrm{Mo}$ plates are underestimated. Otherwise, the fast leakage parameters for zone 3 are too high.

\subsubsection{U-238 Capture/Pu-239 Fission Ratio}

The most serious calculational discrepancy occurs for the breedingperformance determinant, the U-238-capture to $\mathrm{Pu}$-239-fission ratios (C8/F9) 
compared in Table $6-3$. The noted $+11 \%$ to $13 \%$ bias of the analysis is consistent but somewhat higher than past analyses for similar experiments in the Phase I and Phase II GCFR assemblies and in the mockup liquid metal breeder reactor (LMFBR) assemblies. However, the C/Es in Table 6-3 are about $1 \%$ lower than the data of the counterpart ANL calculations.

\subsubsection{U-238/U-235 Fission Ratio}

The relative fission rates between $U-238$ and $U-235$ on a per-atom basis are listed in Table 6-4 for locations in the radial and axial blankets as well as in the core. Here some erratic results are noted for the comparisons at the outer locations in the blankets, indicating that the spectral-moderating properties of the blankets could be better understood. Comparison of $\mathrm{RZ}$ and $\mathrm{XY}$ calculated results at the midplane indicate the increasing difficulties with outer-range flux predictions for the real square-system ZPR using RZ-geometry modeling.

\subsubsection{U-238 Capture/U-235 Fission Ratio}

The capture rates of $\mathrm{U}-238$ relative to the fission rate in $\mathrm{U}-235$ at core and blanket locations are listed in Table 6-5. These ratios are fairly constant throughout the reactor, being the least spectrum-sensitive parameter of the five studies. Also, the calculational discrepancy is remarkably consistent, the $\mathrm{C} / \mathrm{E}$ values ranging between 1.07 and 1.14 . Considering U-235 fission as a better standard reaction rate (better known cross section), the results suggest either a spectrum-independent, overall error in the U-238 capture cross section or an error or bias in the experimental technique. The careful reevaluation of the $\mathrm{U}-238$ and $\mathrm{U}-235$ cross sections in version-5 of ENDF/B are known to have little effect on the $\mathrm{U}-238$-capture/U-235-fission ratio (C8/F5) or the U-238 capture/Pu-239fission ratio ( $\mathrm{C} 8 / \mathrm{F} 9)$. Thus, it would appear that a serious reexamination of the experimental method and calibration is warranted. 


\subsection{DILUTE-SAMPLE FISSION RATIOS}

Other reaction ratios were measured to characterize the central core-cell average spectrum, in addition to the ratios relating to isotopic power splits. The sample placements for these studies spanned the many subregions of the plate or pin cells to achieve an integrated-cell spectrum incldent on the foils. Typical experiments in ZPR systems are the placements of fission-chambers in a cavity created at the core center; direct counting of fission events on well calibrated foils of different isntopes in the chambers [roughly $5.08-\mathrm{cm}$ (2-in.) diameter by $2.54-\mathrm{cm}$ (1-in.) length] gives accurate isotopic fission ratios. However, the analytical interpretations are subject to uncertainties introduced due to the perturbing effects of the cavity and of the chamber structure.

In Phase III, central chamber measurements of U-235/Pu-239 and $\mathrm{U}-238 / \mathrm{Pu}-239$ fission ratios (F5/F9 and $\mathrm{F} 8 / \mathrm{F} 9$ ) were carried out in the reference configuration and in the pin-loaded configuration. Table 6-6 lists the results of these experiments in comparison with corresponding ratios calculated with the core-center spectra from the 2DB calculatinns and the dilute isotope cross sections for U-238, U-235, and Pu-239 (as were used for the core zone 1 sample-worth calculations).

The measured and calculated F8/F9 and F5/F9 ratios in Table 6-6 are seen to be in falr agreement, with $\mathrm{C} / \mathrm{E}$ ratios between 0.992 and 1.025 . However, it must he noted that no corrections have been made for the effects of the fission-chamber structure and the cavity on the foil-incident spectra; a depression of the U-238 fission rate by as much as $10 \%$ has been estimated in past ZPR-9 studies. The last column in Table 6-6 lists the comparable fission ratios measured in the cell fuel plates (from Section 6 data), and it shows that the U-238 fission rate measured inside the chamber is $7 \%$ to $9 \%$ less than the in-pin or in-plate rates. 
TABLE 6-6.

COMPARISON OF MEASURED AND CALCULATED SPECTRAL INDICES AT CENTER OF PHASE .III CORE

\begin{tabular}{|c|c|c|c|c|c|}
\hline $\begin{array}{c}\text { Reactor } \\
\text { Configuration }\end{array}$ & $\begin{array}{l}\text { Reaction } \\
\text { Ratio } \\
\text { (per atom) }\end{array}$ & $\begin{array}{c}\text { Measured } \\
\text { Value, Chamber } \\
\text { In Central } \\
\text { Cavity }\end{array}$ & $\begin{array}{l}\text { Calculated } \\
\text { Value for } \\
\text { Dilute } \\
\text { Sample (a) }\end{array}$ & $\begin{array}{l}\text { Calculated to } \\
\text { Experimental } \\
\text { Ratio, } \\
\text { C/E }( \pm 1.5 \%)\end{array}$ & $\begin{array}{l}\text { In-Plate } \\
\text { Foil } \\
\text { Measurement } \\
\quad( \pm 1.8 \%)\end{array}$ \\
\hline $\begin{array}{l}\text { Plate-core, } \\
\text { reference: } \\
\text { loading }\end{array}$ & $\begin{array}{l}\mathrm{F} 8 / \mathrm{F} 9 \\
\mathrm{~F} 5 / \mathrm{F} 9 \\
\mathrm{C} 8 / \mathrm{F} 9 \\
\mathrm{C} 9 / \mathrm{F} 9\end{array}$ & $\begin{array}{l}0.0249 \pm 0.0003 \\
1.040 \pm 0.013(\mathrm{~b}) \\
0.143 \pm 0.003(\mathrm{~b}) \\
0.272 \pm 0.040\end{array}$ & $\begin{array}{l}0.02552 \\
1.0344 \\
0.149 .5 \\
0.2552\end{array}$ & $\begin{array}{l}1.025 \\
0.995 \\
1.045 \\
0.938\end{array}$ & $\begin{array}{l}0.0274 \\
1.044 \\
0.1272 \\
\quad--\end{array}$ \\
\hline $\begin{array}{l}\text { Pin-cell loading } \\
\text { in central core } \\
\text { zone }\end{array}$ & $\begin{array}{l}\text { F8/F9 } \\
\text { F5/F9 } \\
\text { C8/F9 } \\
\text { C9/F9 }\end{array}$ & $\begin{array}{c}0.0259 \pm 0.0003 \\
1.0350 \pm 0.013 \\
-\end{array}$ & $\begin{array}{l}0.025 .95 \\
1.0263 \\
0.1454 \\
0.2473\end{array}$ & $\begin{array}{c}1.002 \\
0.992 \\
-- \\
--\end{array}$ & $\begin{array}{l}0.0279 \\
1.056 \\
0.1267 \\
\quad--\end{array}$ \\
\hline
\end{tabular}

(a) Derived with centermost mesh, cell average spectrum and dilute isotope cross sections.

(b) Inferred from $(1+\alpha)$ measurements (Section 8 ) in radial traverse guide tube. 
A comparison of the central fission ratios in Table 6-6 for the pin loading versus the plate loading reveals a slightly harder cell-average neutron spectrum for the pin environment. This is confirmed by the central spectra comparisons in Table $3-1$ and is due to the lower concentrations of steel and oxygen in the pin loading (see Table $A-1$ ).

\subsection{DILUTE-SAMPLE CAPTURE RATIOS}

Included in Table 6-6 are the capture-to-fission ratios, $U-238(n, \gamma) /$ $\mathrm{Pu}-239(\mathrm{n}, \mathrm{f})$ and $\mathrm{Pu}-239(\mathrm{n}, \gamma) / \mathrm{Pu}-239(\mathrm{n}, \mathrm{f})$ derived on the basis of the measurements of $(1+\alpha)$ for $\mathrm{U}-238$ and $\mathrm{Pu}-239$ (in section 9 ) and the above dilute-sample fission ratios. The $\alpha$ evaluations were also dilute-sample representations, based on reaction rate and worth measurements carried out in the radial traverse tube. Again, the calculated capture-to-fission ratios were derived using cell-average spectra and dilute-sample cross sections.

The calculated-to-experimental ratio for the dilute-sample evaluation of C8/F9 in the plate-core is 1.045 , indicating $4.5 \%$ overprediction of this breeding parameler. Huwever, a proper accounting in the analysis for the resonance dilution and spectrum softening by the traverse tube steel would yield a higher calculational discrepancy. Note that the measured ratio. in the cell-average spectrum (in the tube) is $12 \%$ higher than the $\mathrm{C} 8 / \mathrm{F} 9$ ratio given by in-plate foil irradiations, as a result of more resonance dilation, softer spectrum environment, and possible different measurement techniques. Also, this $\mathrm{GA}$-calculated $\mathrm{C} 8 / \mathrm{F} 9$ ratio is about $3 \%$ higher than the corresponding results of ANL calculations for dilute isotopes.

The GA-calculated dilute-sample value for $\mathrm{Pu}-239 \alpha$ 1s $6 \%$ lower than the value derived from the $(1+\alpha)$ measurement for small sampies and foils in the traverse tube, the same discrepancy as given by ANL calculations. Here the probable cause is that the cell-average spectrum assumed by the calculation is harder than that present in the surroundings of the thin-sample measurements. 


\subsection{ABSOLUTE REACTION RATES}

As part of the analysis for the foregoing evaluations of dilute-sample capture and fission ratios, absolute reaction rates were calculated for a number of elements and isotopes at the core center. Table 6-7 lists these core-center dilute isotope capture and fission rates, given by the 2DB edits, normalized to a total assembly power level of $1 \mathrm{~kW}$. Also listed are the effective one-group average reaction cross sections in the central cell-average spectrum of this plate reference configuration.

One other dilute-sample ratio obtained in the Phase III experiments was that of capture in $\mathrm{Li}-6$ to fission in $\mathrm{Pu}-239$ as part of the $1+\alpha$ measurement technique. The measured central per-atom ratio, Li-6 $(n, \alpha) /$ Pu-239 ( $n, f)$, was $0.611 \pm 0.007$, in excellent agreement with a value of 0.608 given by the calculated data in Table 6-7. 
TABLE 6-7

CALCULATED REACTION RATES FOR DILUTE-SAMPLE ISOTOPES AT CENTER OF PHASE III CORE

\begin{tabular}{|c|c|c|c|c|}
\hline \multirow{2}{*}{ Isotope } & \multicolumn{2}{|c|}{$\begin{array}{l}\text { Absolute Reaction Rate } \\
\text { for } 1 \mathrm{~kW} \text { Total Reactor } \\
\text { Power }\left(10^{7} \text { events/g-s }\right)\end{array}$} & \multicolumn{2}{|c|}{$\begin{array}{l}\text { Effective: Reaction Cross } \\
\text { Section (barns): in } \\
\text { Cell Avg. Spectrum (a) }\end{array}$} \\
\hline & Fission & Capture & Fission & Capture \\
\hline Li-6 & -- & 113.28 & -- & 1.0737 \\
\hline B- 10 & -- & 156.83 & -- & 2.475 \\
\hline Th-232 & 0.2798 & 0.9904 & 0.01023 & 0.3621 \\
\hline $\mathrm{U}-233$ & 7.259 & 0.6379 & 2.6657 & 0.2475 \\
\hline $\mathrm{U}-235$ & 4.937 & 1.4028 & 1.8288 & 0.5196 \\
\hline $\mathrm{U}-238$ & 0.1200 & 0.7032 & 0.0450 & 0.2638 \\
\hline$P_{u-2} 238$ & 3.1411 & 0.9870 & 1.1783 & 0.3702 \\
\hline $\mathrm{Pu}-239$ & 4.6858 & 1. 1958 & 1.7652 & 0.4505 \\
\hline $\mathrm{Pu}-240$ & 1.0535 & 1.2197 & 0.3985 & 0.4614 \\
\hline $\mathrm{Pu}-241$ & 6.2342 & 1.1172 & 2. $3688 ?$ & 0.4244 \\
\hline $\mathrm{Pu}-242$ & 0.8068 & 0.7964 & 0.3078 & 0.3039 \\
\hline
\end{tabular}

(a) For $1 \mathrm{~kW}$, total reactor power, total flux at centermost mesh interval calculated as $1.05366 \times 10^{10}$ neutrons $/ \mathrm{cm}^{2}-\mathrm{s}$. 


\section{REACTION RATE PROFILES}

The radial and axial distributions of the fission rates of $\mathrm{Pu}-239$, $\mathrm{U}-238$, and $\mathrm{U}-235$ and the U-238 capture rate within the cell average fuel and fertile materials were measured using the foil activation procedure described in Section 6.1. The foils were emplaced at regular intervals along the reactor axis and near the front of each drawer of matrix column 23 ascending from the central drawer (23/23). Single foils were irradiated at regular mapping-foil cell locations and the results converted to cell-average rates for the fuel and fertile materials using the in-cell rate distributions discussed earlier. The acquired fission-rate scans thus characterize the true reactor power distribution, and the U-238 capture scans quantify the spatial conversion rate distribution important in evaluating the breeding ratio.

\subsection{RADIAL REACTION-RATE DIGTRIBUTIONS}

The relative reactions rates measured in the radial direction in the assembly, actualiy in the vertical direction in the ZPR framework, are plotted in Figs. 7-1 through 7-5 in comparisons with the corresponding calculated reaction profiles. For these scans, the calculated data were derived using the real fluxes from the XY-geometry $2 \mathrm{DB}$ case for the Phase III reference configuration and the zone-dependent cell-average cross sections for U-235, U-238, and Pu-239. The calculations were done for points along the $Y$ axis, to correspond to the situation of the measurements, and thus account.for the stronger neutron leakage properties in this direction than in the $X$ direction of the $X Y$ case or in the $R$ direction of the $R Z$ case. Both measured and calculated data have been normalized to 1000 at the core axis $(r=0.0)$.

Figures 7-1 and 7-2, for the radial profiles of fission in $\mathrm{Pu}-239$ and U-235, show very good agreement of the calculations with measurements 


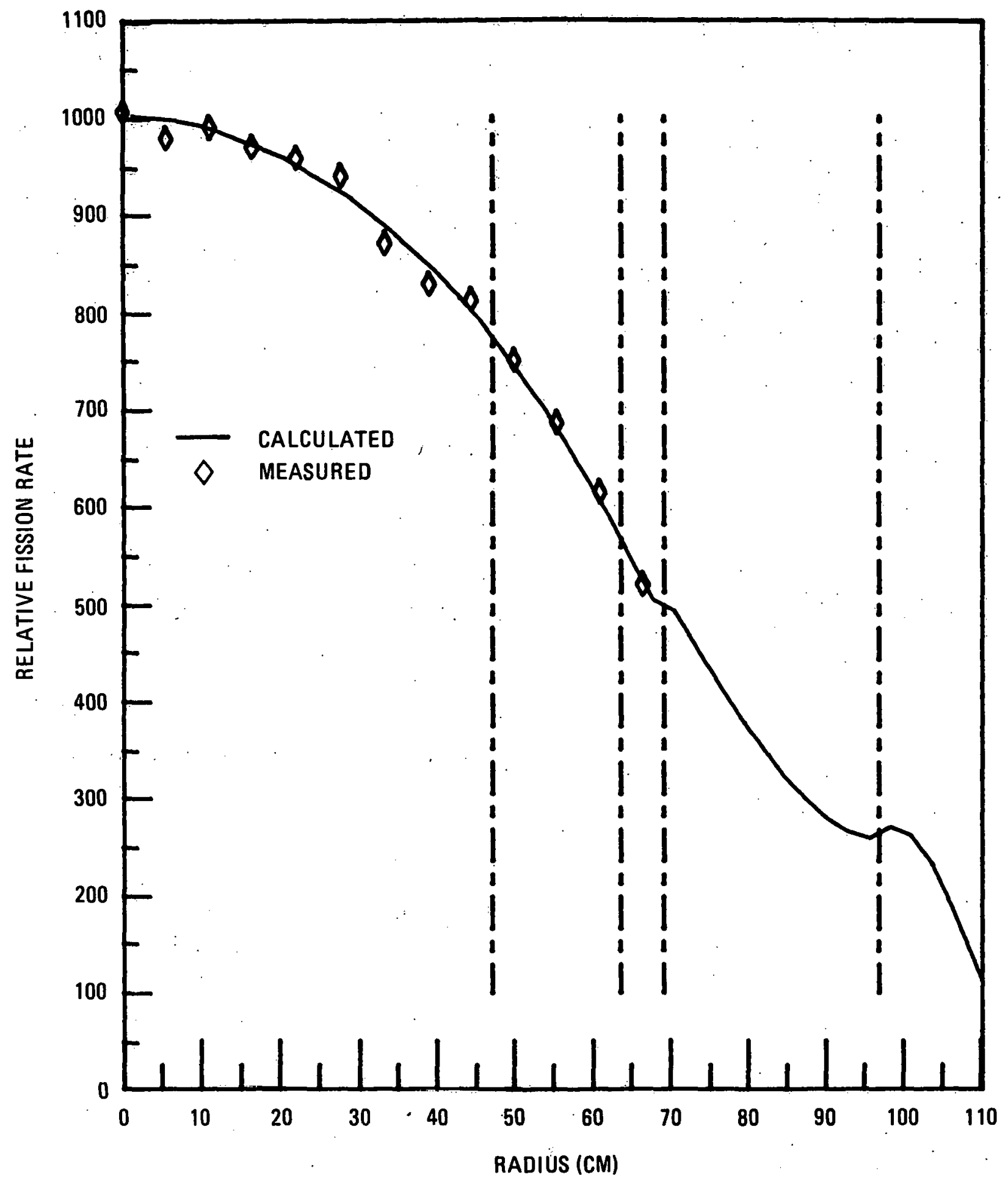

Fig. 7-1: Pu-239 radial fisston rate profile 


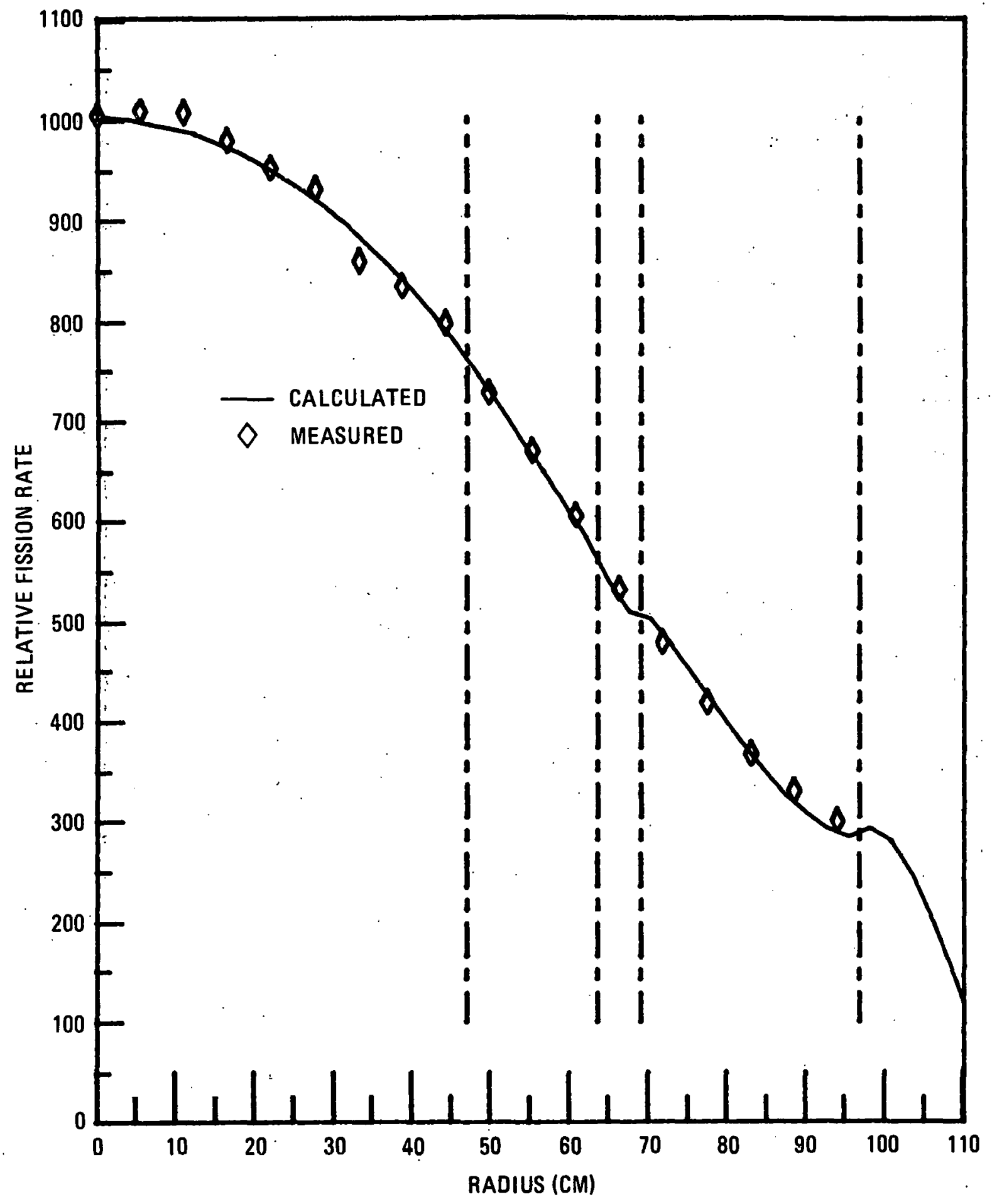

F1g. 7-2. U-235 radial fission rate profile 


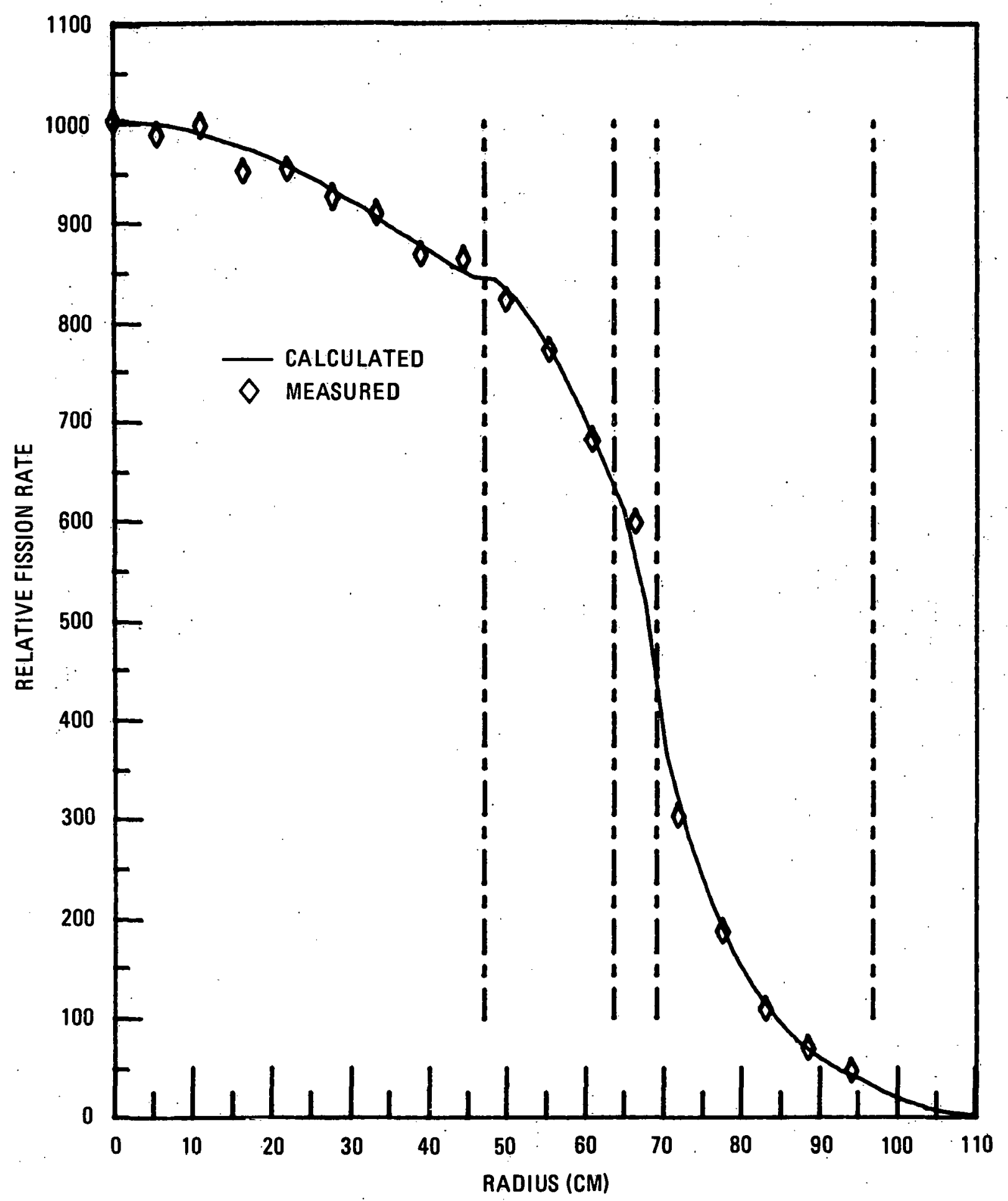

F1g. 7-3. U-238 radial fission rate profile 


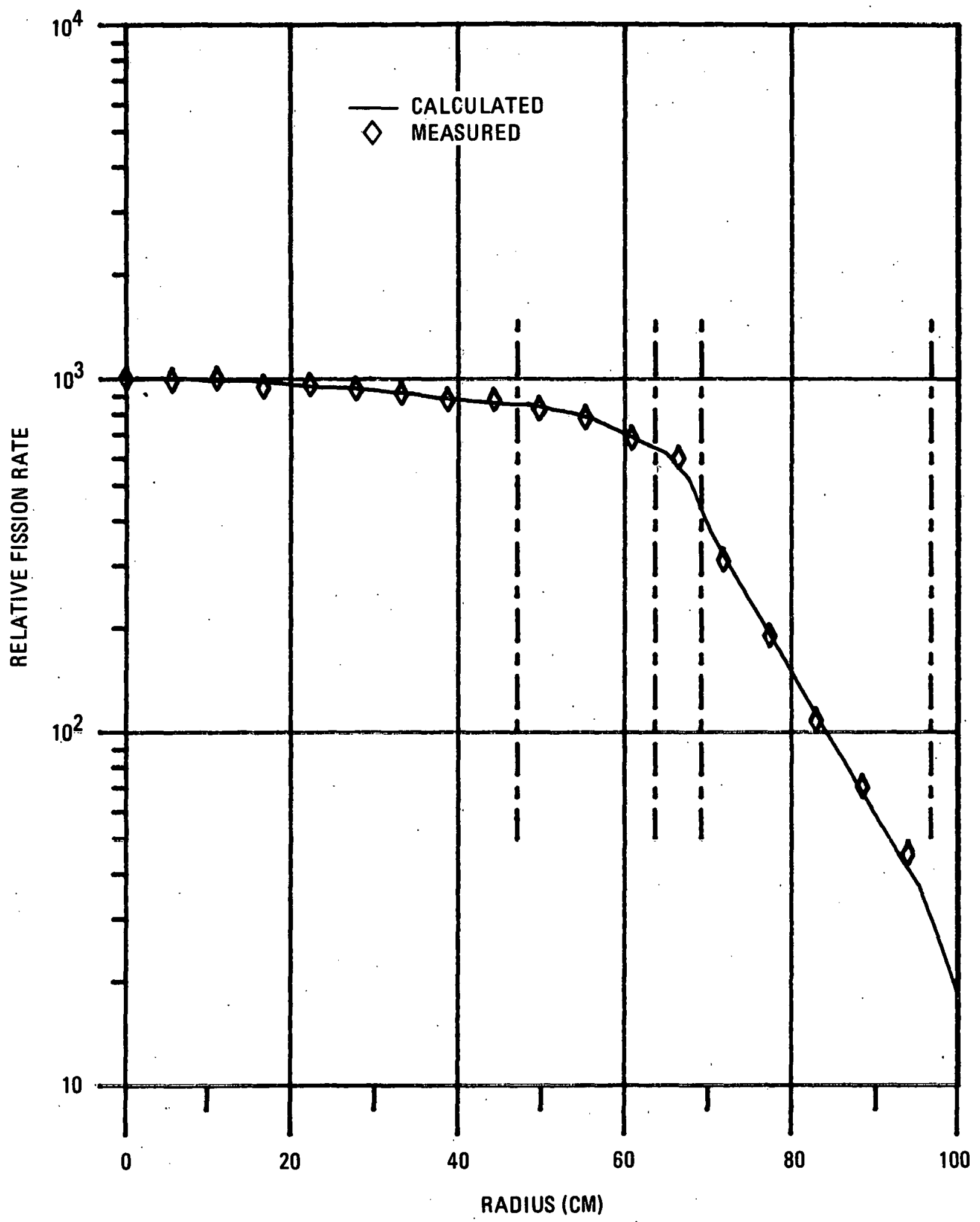

Fig. 7-4. U-238 radial fission rate profile, logarithmic scale. 


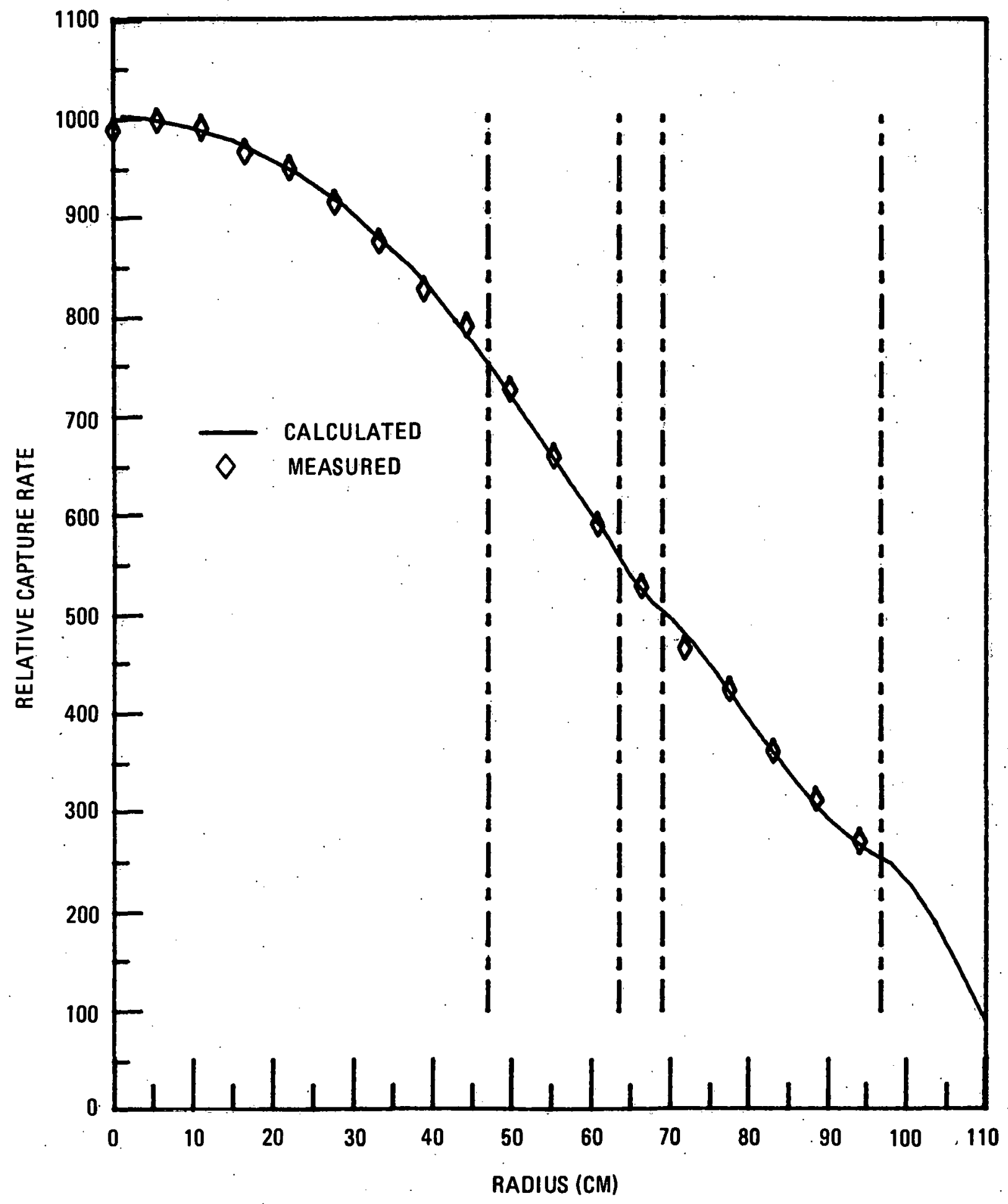

F1g. 7-5. U-238 radial capture rate profile 
throughout the core and most of the radial blanket, considering the scatter of the measured points. Furthermore, the normalized calculations, based on 10-group analysis, are for the most part identical with the ANL-calculated profiles generated using 29 cross-section groups.

Similar good agreement of measurements with calculations is observed in Fig. 7-3 for the U-238-fission radial scan, although the relative fission rate for $\mathrm{U}-238$ in core zone 3 (within the $\mathrm{Pu}-\mathrm{U}-\mathrm{Mo}$ plates) appears underpredicted by about $8 \%$, as noted earlier in the discussion of fission ratios. Figure 7-4 shows these same measured and calculated data plotted on a logarithmic scale to illustrate that the good agreement for this Fission-rate prediction extends through the radial blanket. Thus, the high-energy neutron flux profiles are well calculated out to the inside edge of the reflector.

The calculated and measured radial capture rate distributions for U-238 are plotted in Fig. 7-5, showing excellent agreement throughout the core and blanket regions. This may be surprising, considering the large discrepancy of the $C 8 / F 5$ reaction-ratio calculations $(C / E=1.13)$, but could be expected because of the consistency of the $\mathrm{C} / \mathrm{E}$ for the $\mathrm{C} 8 / \mathrm{F} 5$ ratio in combination with a U-235 fission profile which also was well predicted. The capture cross section $(n, \gamma)$ for $U-238$ is fairly energy dependent, and it is difficult to realize how errors in the basic data for this reaction could yield the high $C / E$ for the C./F5 ratios and at the same Lime not distort the comparison of measured versus calculated reaction distributions, unless the $\sigma(n, \gamma)$ error 1s energy independent.

\subsection{AXIAL REACTION RATE DISTRIBUTIONS}

Calculations for. the fission and capture rates in the cell average fuel and fertile materials as a function of axial position were carried out using the fluxes along the $Z$ axis from the RZ-model $2 \mathrm{DB}$ calculations and the isotopic cross sections for the core zone 1 and axial blanket regions. The 
comparisons of these calculations with the measured axial reaction profiles are plotted in Figs. 7-6 through 7-10.

The axial fission rate distributions for Pu-239 are shown in Fig. 7-6; here, the agreement of the calculated curve with the measured data is not as good as found in the radial direction (Fig. 7-1), with the analysis underpredicting the normalized fission rate by about $3 \%$ to $4 \%$ in the core near the axial blanket. A similar pattern occurs for the U-235 fission profiles in the çore, plotted in Fig. 7-7, but with good predictions of the U-235 fission rate variation in the axial blanket. The calculational/ experimental deviation for the rates along the axis in the core suggest that the average leakage parameters, most probably the axial diffusion modifiers, are calculated slightly too low on a whole-spectrum basis.

Figures $7-8$ and $7-9$ are plots of the $U-238$ axial fission rate distributions. As for the radial direction, the calculated results in the core agree with the measured U-238 fission-rate scans to within the apparent precision of the experiments. The logarithmic plot in Fig. 7-9 shows some deviation in the attenuation rates (the slopes) in the axial blanket, indicating some misprediction of the high-energy macroscopic removal cross sections for the axial blanket.

The axial capture-rate distributions for U-238 are plotted in Fig. 7-10, and except for an anomalous measured point, the agreement of the analysis with experiments is excellent in both core and blanket regions, as was the case for the radial scans also. However, the good profile prediction for this capture rate, which is a broad-spectrum parameter, seems inconsistent with the $C / E$ profile deviations noted for the U-235 axial fission-rate scan (Fig. 7-7).

\subsection{POWER PROFILE CALCULATIONS}

As a study of the effects of different assembly models, the midplane power-density distributions edited by the RZ- and XY-geometry 2DB 


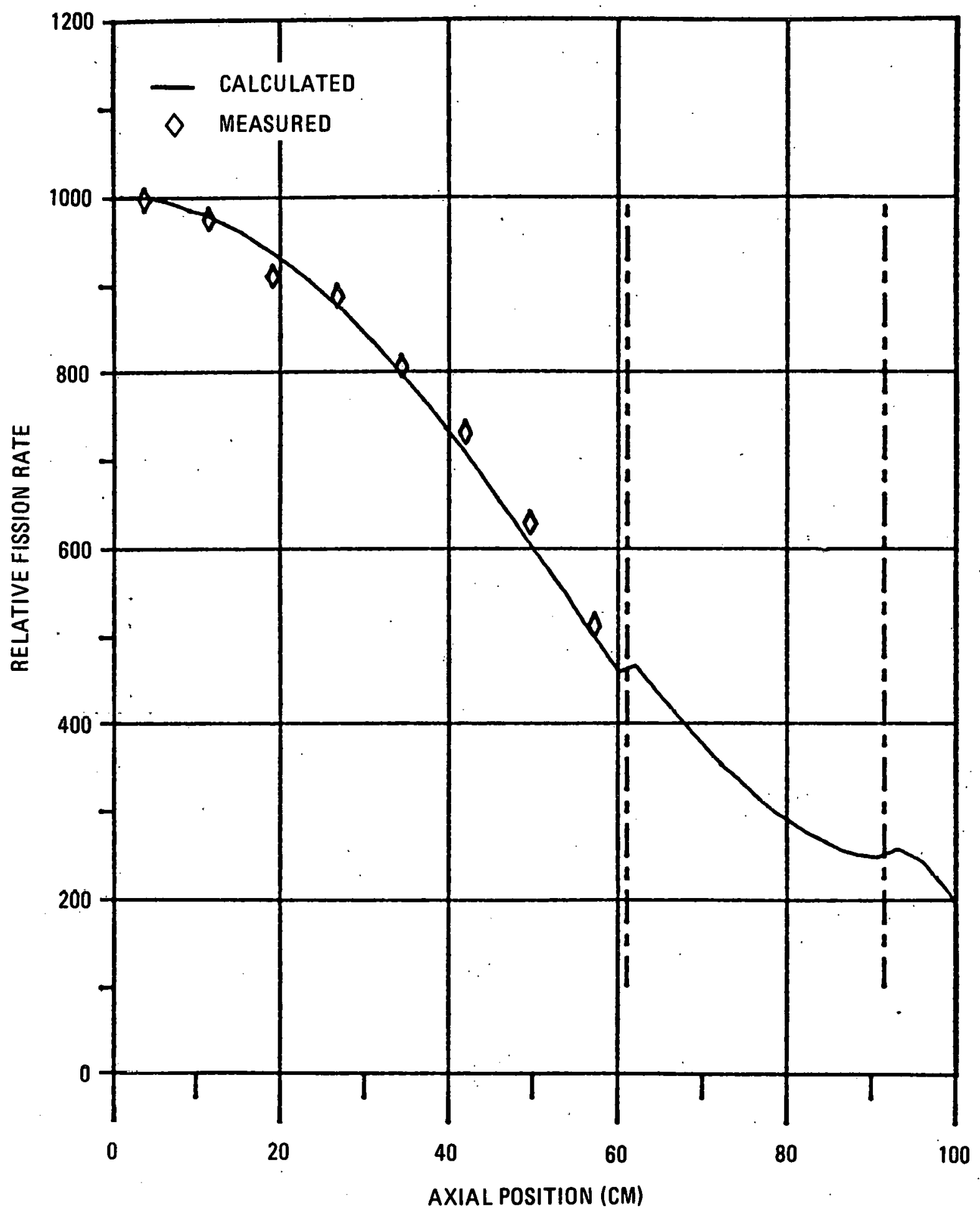

F1g. 7-6. Pu-239 axial fission rate distribution 


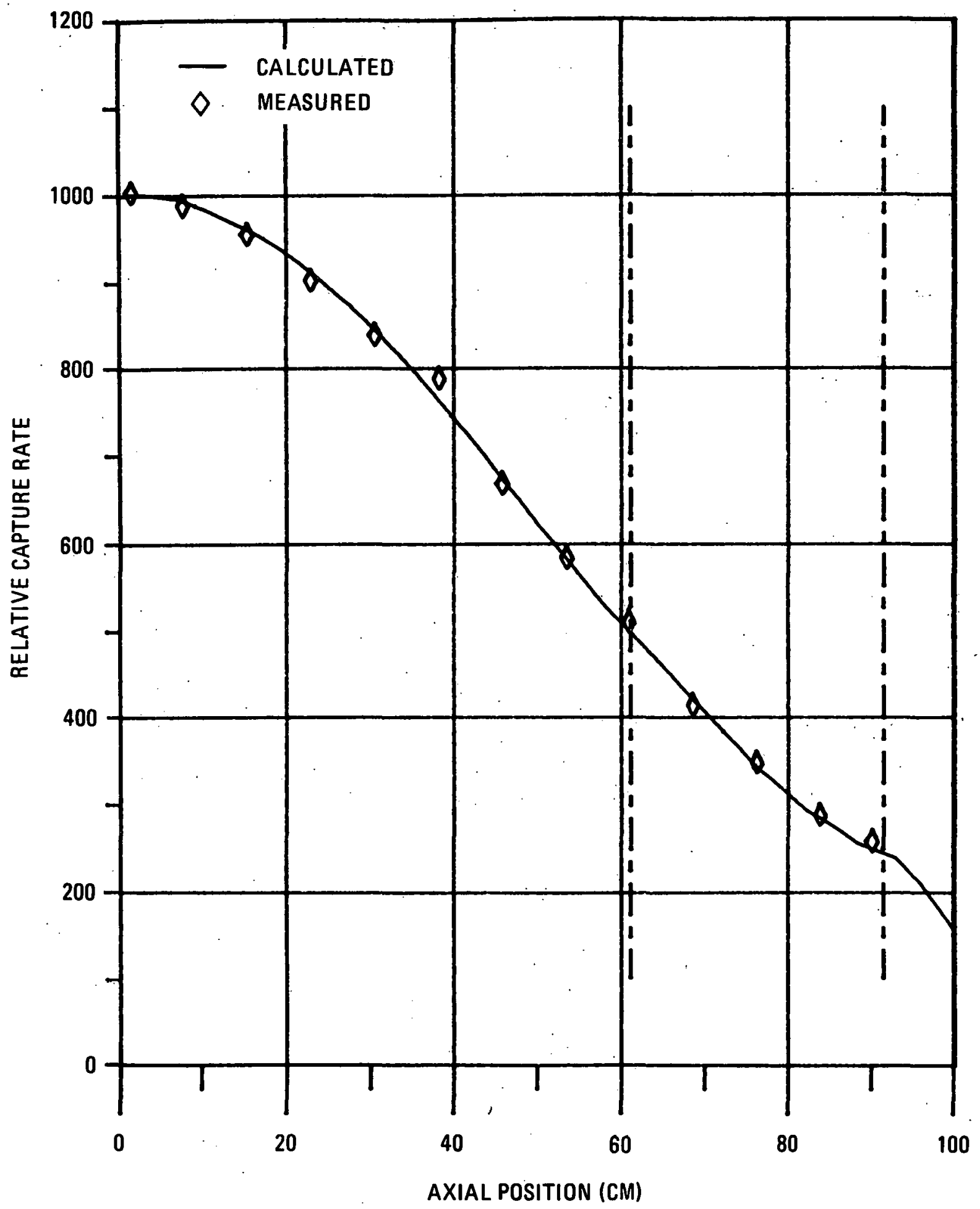

F1g. 7-7. U-235 axial fission rate distribution 


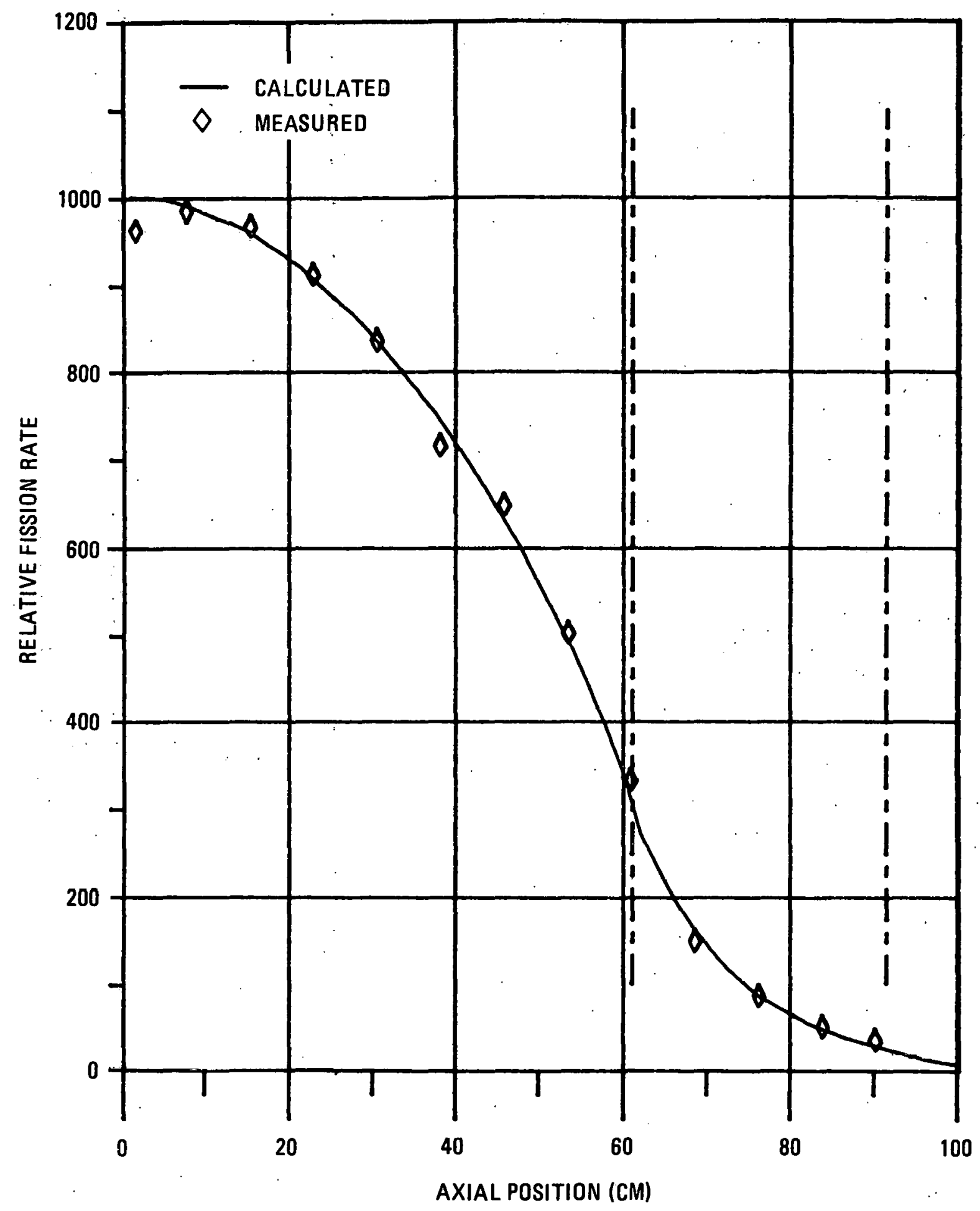

F1g. 7-8. U-238 axial fission rate distribution 


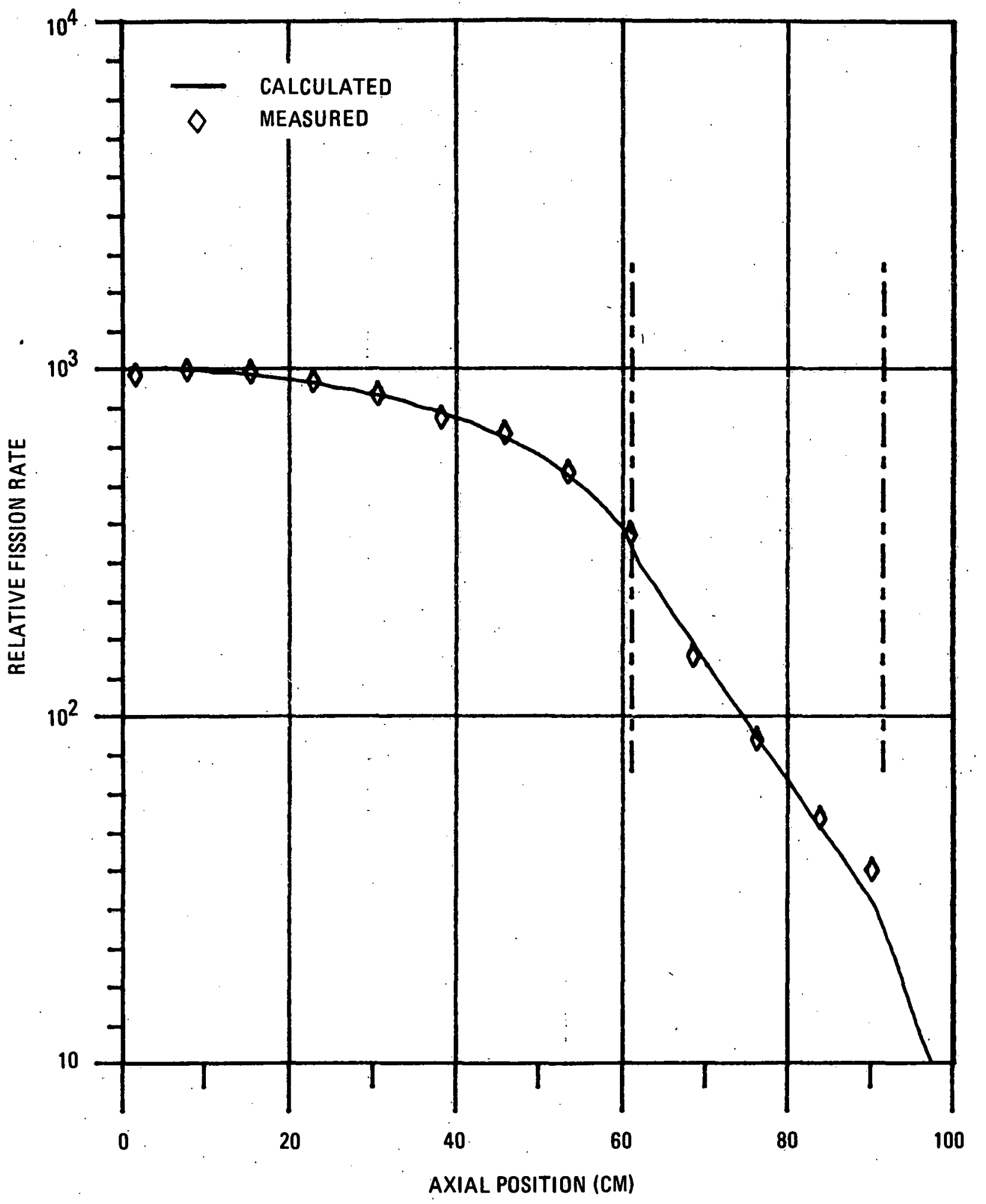

Fig. 7-9. U-238 axial fission rate distribution, logarithmic scale.

7-12 


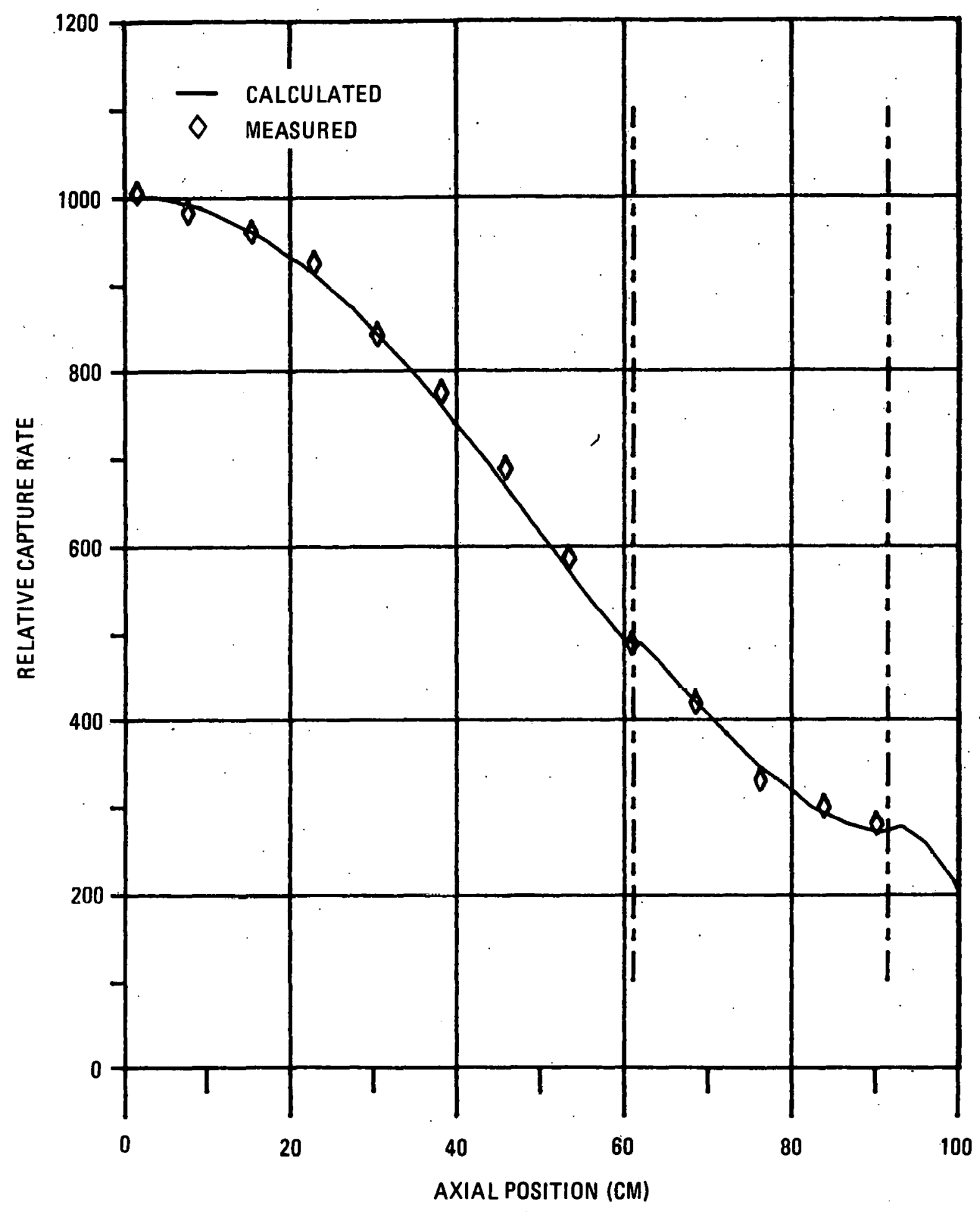

Fig. 7-10. U-238 axial capture rate distribution 
calculations have been plotted together on Fig. 7-11. From the XY case, the distributions along both of the $\mathrm{X}$ and $\mathrm{Y}$ axes are given, shown as dashed curves, and the radial power profile from the $R Z$ case is plotted as the solid line. The graph shows how the $X$ and $Y$ distributions deviate increasingly as a function of radius as a result of the significantly larger streaming modifiers supplied for the vertical direction in the assembly. In the outer core zone, the difference in $\mathrm{X}$ - and $\mathrm{Y}$ - direction power densities, and thus the flux levels, approaches $5 \%$ (higher along the vertical axis).

The radial power distribution from the $R Z$ calculation shows distances from the core axis of the enrichment zone boundaries, produced by the cylindrical modeling, that differ from the XY counterparts. For the $R$ direction, the streaming modifiers were the average of the $X$ and $Y$ modifiers, yet the $\mathrm{RZ}$ radial profile concurs with the vertical profile from the $X Y$ case instead of falling between the $X$ and $Y$ results. The higher-than-expected radial distribution is probably a result of the larger outer core dimensions inherent to the modeling.

The radial material-worth profiles through the assembly were measured by traversing samples through a tube along the $\mathrm{X}$ axis, whereas the calculated worth profiles necessarily used the radial flux distributions from the RZ-2DB calculations. That the measured and calculated fissile material worth profiles agree so well implies that the RZ radial flux profile more accurately represents the flux distribution along the $X$ axis, which is contrary to the plots in Fig. 7-11. These considerations bear out a suspicion that the PLADIF-generated diffusion modifiers for the $X$ direction (perpendicular to plates) underestimate the true cell leakage properties in that direction.

\subsection{REACTION RATE SCANS THROUGH RADIAL TRAVERSE TUBE}

Additional reacton rate profiles were measured as part of the isotopic $1+\alpha$ determinations (Section 8). Foils of Li-6 and Pu-239 were irradiated at several radial positions within the guide tube for the reactivity sample 


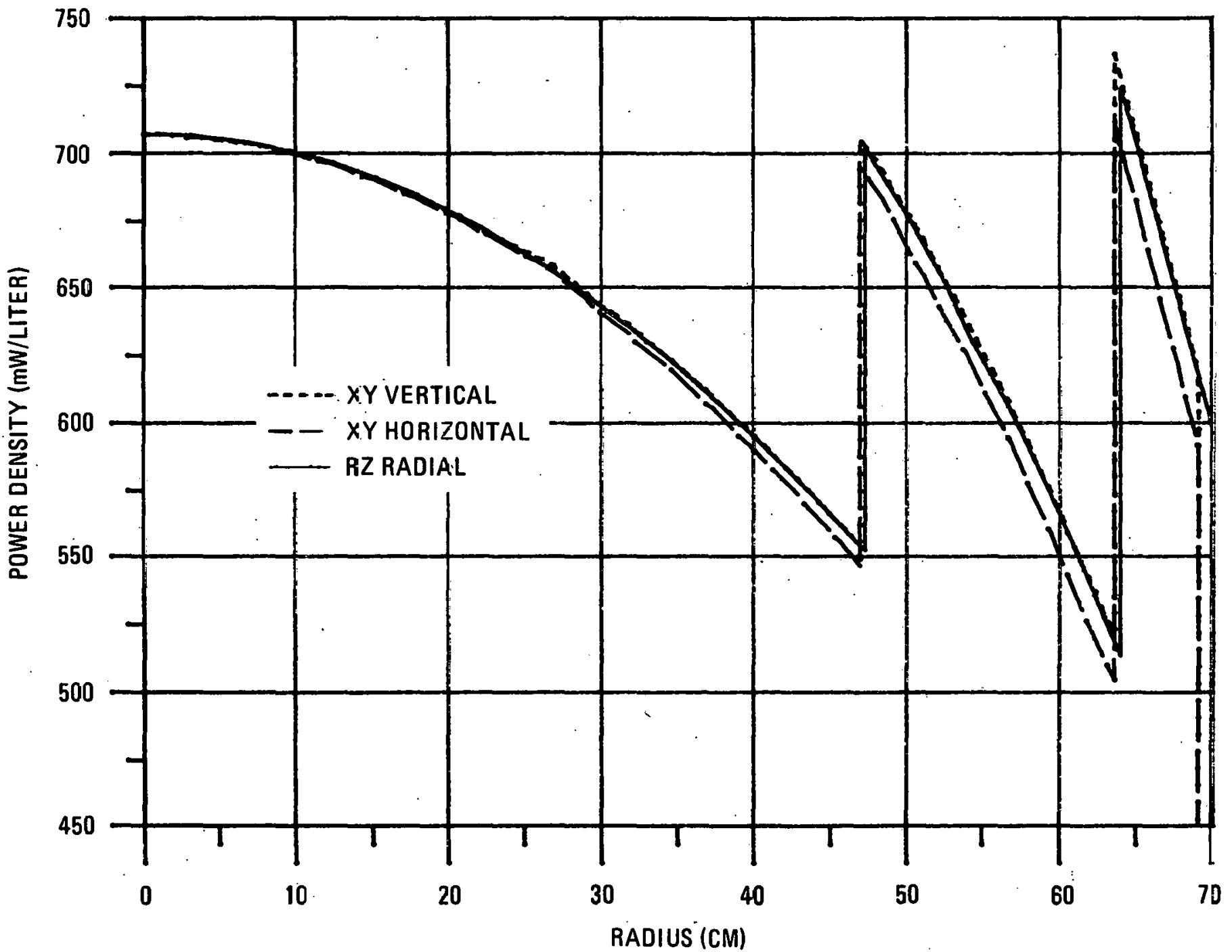

Fig. 7-11. Phase III radial power profiles at $1 \mathrm{~kW}$ 
traverse mechanism. Figures $7-12$ and $7-13$ show the measured radial profiles for the thin-sample $\mathrm{Pu}-237(n, f)$ and $\operatorname{Li}-6(n, \alpha)$ reaction rates, respectively, in comparison with calculated dilute-sample profiles: In Fig. 7-12, two calculated Pu-239 fission profiles are shown, as derived from the $\mathrm{RZ}$-and $\mathrm{XY}$-geometry 2DB calculations. The radial fission distribution from the RZ calculation is in better agreement with the traverse tube Pu-239 fission scan than the $X$-direction profile derived from the XY calculation, which should more accurately portray the situation of the traverse tube running horizontally through the row 23 drawers. In addition to the suspected low diffusion modifiers for the $\mathrm{X}$ direction, steaming problems associated with the traverse tube may be responsible for the calculated-to-experimental discrepancy for this fission-rate scan.

A similar comparison of profiles was obtained for the Li-6 $(n, \alpha)$ reaction rate distribution through the traverse tube, shown in Fig. 7-13. The calculated Li-6 capture profile derived from the XY-case 2DB flux distribution is seen to deviate significantly from the measurements with increasing distance from the core axis. The disagreement for the capture rate is in marked contrast with the well-calculated (normalized) Li-6 radial-worth profile in Fig. 5-6, where the real and adjoint flux profiles came from the RZ-geometry $2 \mathrm{DB}$ case. 


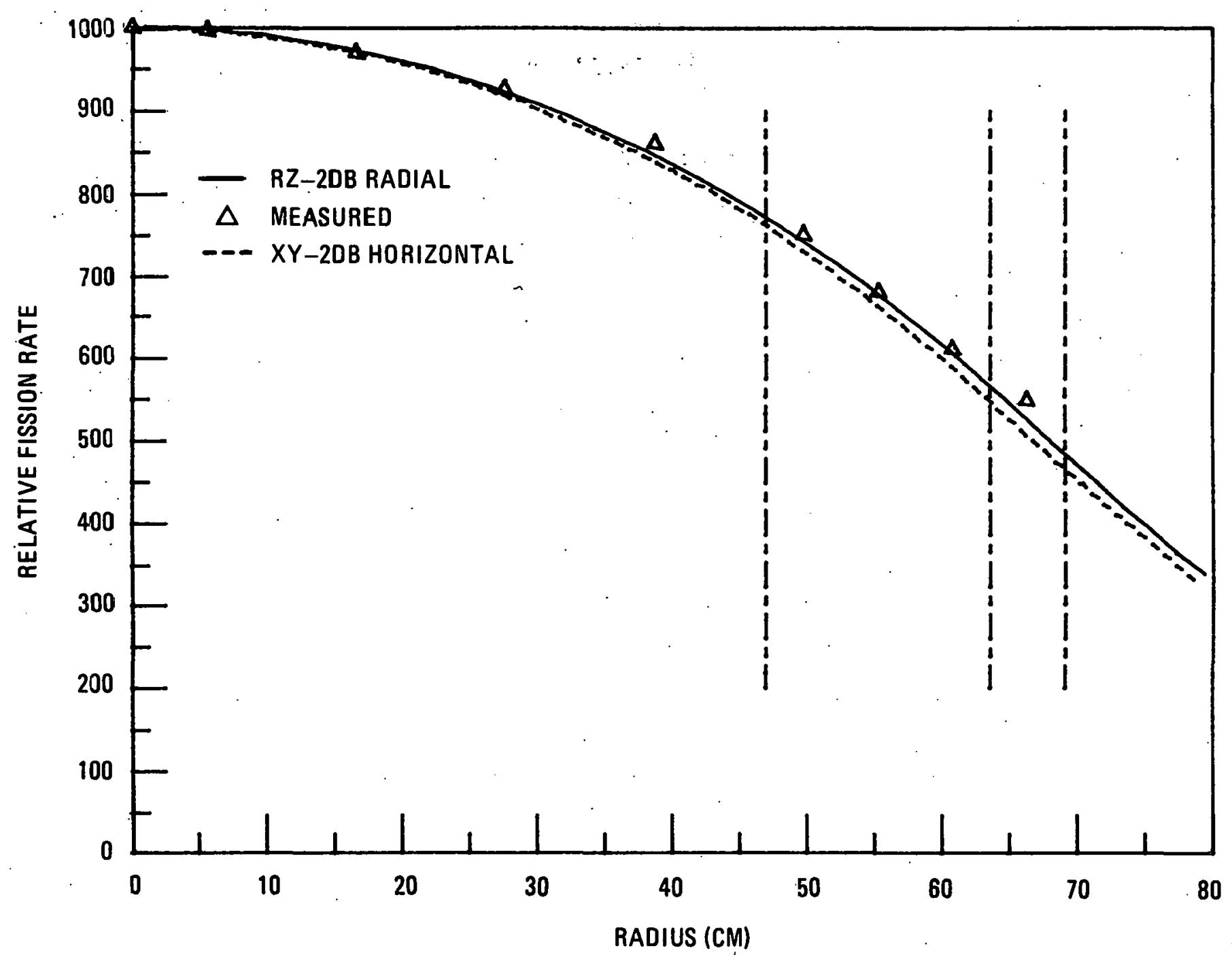

Fig. 7-12. Pu-239 fission rate scan in radial traverse tube 


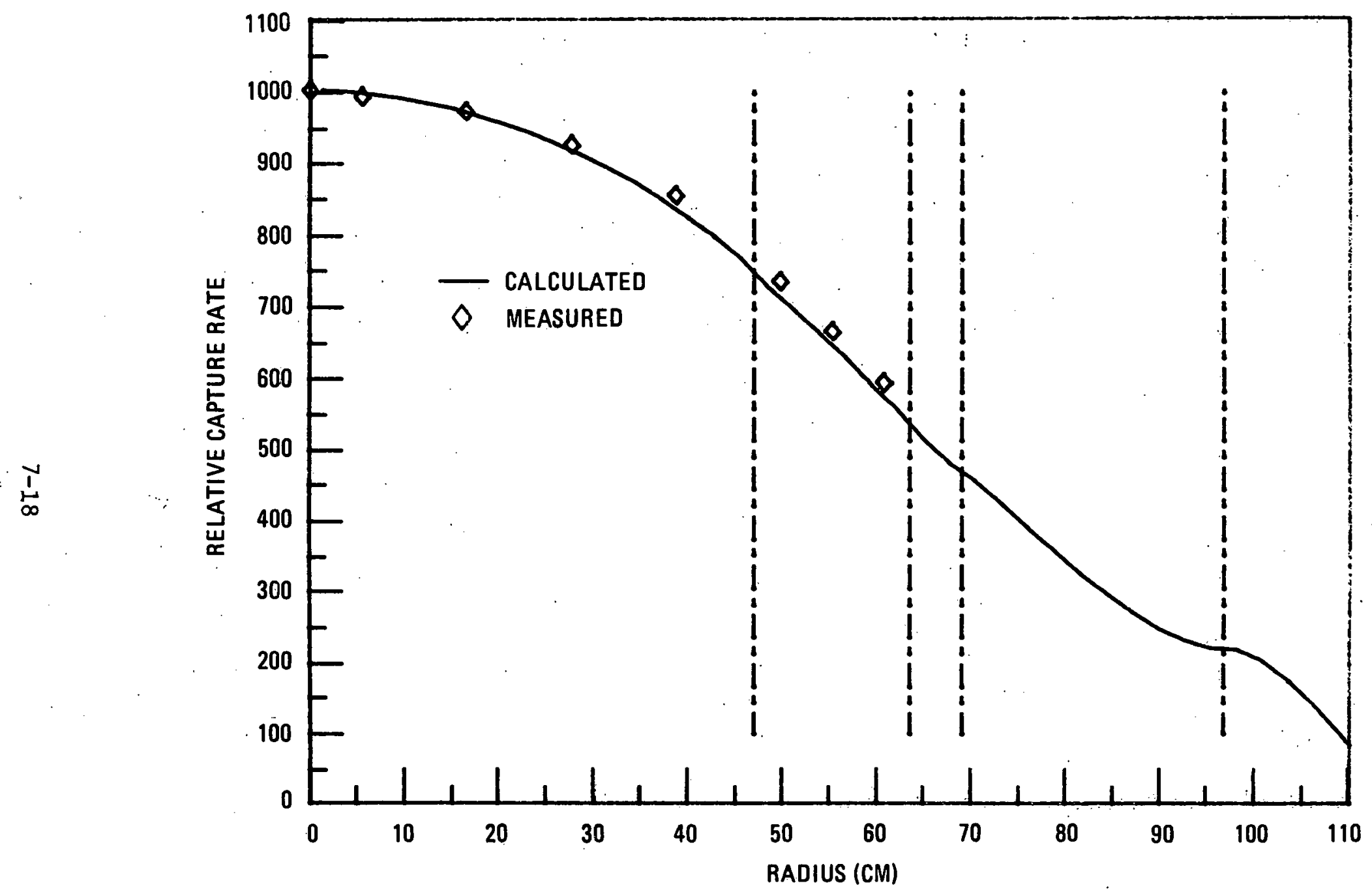

Fig. 7-13. Li-6 radial capture rate profile 


\section{CENTRAL CONVERSION RATIO EXPERIMENT}

A technique has been developed at ANL for measuring breeding-ratio parameters on mockups of power reactors without resorting to high integrated-power irradiations as required for radiochemical analyses. The essence of the method is the evaluation of isotopic absorption-to-fission ratios $(1+\alpha)$ as a function of location by comparing the worth of the fissile material, which depends on capture and fission, and the relative fission rate; the procedure is known as the reactivity/reaction-rate method (Ref. 19). The measurements required by the method include fission ratios for fuel isotopes relative to Pu-239 fission, the fissile-sample worths, a worth traverse for a Li-6 sample, a corresponding absolute Li-6 $(n, \alpha)$ reaction-rate traverse, and traverses to derive the apparent worth of a Cf-252. spontaneous fission neutron source. Also, a number of calculated correction factors are needed (for worths of nonfission absorption processes, etc).

\subsection{ABSORPTION-TO-FISSION RATIOS}

The absorption-to-fission ratio $(1+\alpha)$ for a fissionable isotope is decermined in the method according to the formulation

$$
1+\alpha^{i}+E^{i}=\frac{R_{\alpha}^{L i}}{R_{f}^{i}} \cdot \frac{\rho^{i}}{\rho^{L i}} \cdot I_{a}^{*}\left[\frac{\rho s}{\rho^{i}} \cdot \frac{R_{f}^{i}}{s^{C f}} \cdot I_{f}^{*}-C^{i}\right] \cdot \frac{A^{L i}}{C^{L i}},
$$

where $\quad R=$ reaction rates,

$$
\begin{aligned}
\rho^{i} & =\text { isotopic worths, } \\
\rho_{S} C f & =\text { apparent worth of } \mathrm{Cf}-252 \text { neutron source, and }
\end{aligned}
$$$$
\mathrm{S} C \mathrm{f}=\text { source strength. }
$$

All of these are determined for a standard power level. The calculated factors are 


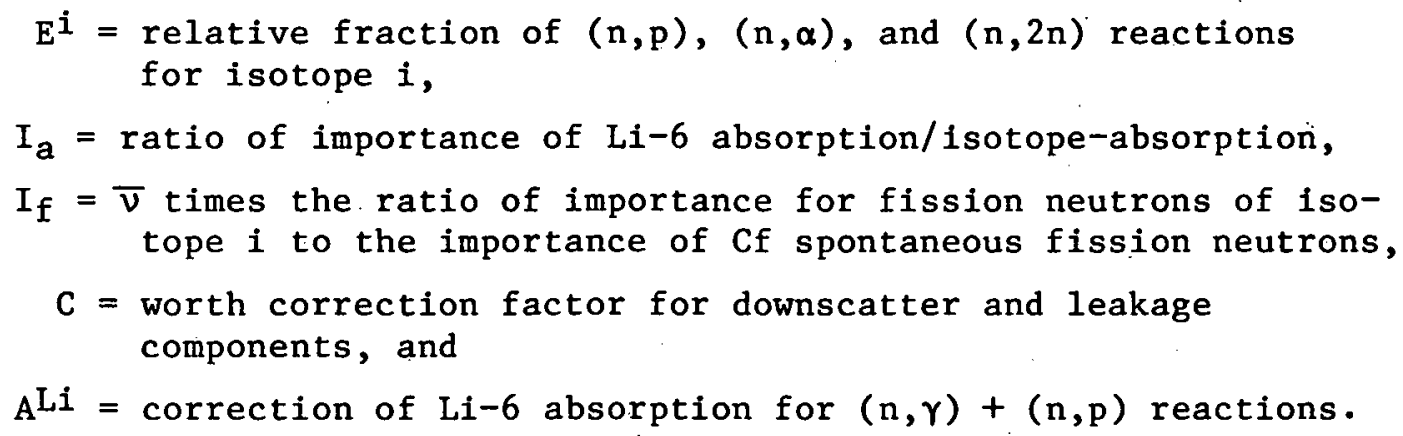

As can be seen, there are a number of calculated adjustments which can add a degree of uncertainty to the evaluations. The uncertainty of the. $(1+\alpha)$ determination propagating from the measured parameters depends on the accuracy of the reaction-rate ratios and the material-worth ratios.

Since the fissionable material worths were measured using small samples in the horizontal guide tube, and exposed to the integral flux over the drawer-wide cells, the corresponding reaction rate ratios were derived from similar dilute-sample experiments. Table 8-1 presents the results of the ANL measurements for the absorption-to-fission ratios $(1+\alpha)$, in the isotopes U-233, U-235, U-238, $\mathrm{Pu}-239$, and $\mathrm{Pu}-240$. The U-233 and $\mathrm{Pu}-240$ measurements involve more empirical adjustments since their fission ratios (to $\mathrm{Pu}-239$ ) were not actually measured.

Table 8-1 also gives the comparable calculated $(1+\alpha)$ values for dilute isotopes derived from the Table 6-7 data. For Pu-239, the calculations are seen to underpredict the absorption/fission ratio by a relatively constant amount, about 4\%, throughout the cores for these thinsample measurements. A similar result is noted for U-235.

For $U-238$, the $(1+\alpha)$ value, and thus also the isotopic capture-to-fission ratio, is surprisingly well calculated. It must be borne 1n mind, however, that this pertains a cell-spanning thin sample; not necessarily the same applies for processes in the fuel plates. Also, the correction factors are larger for the U-238 worths and reaction rates. 
TABLE 8-1

ABSORPTION-TO-FISSION $(1+\bar{\alpha})$ RATIOS FOR DILUTE FUEL ISOTOPES IN CORE OF PHASE III GCFR CRITICAL ASEMBLY

\begin{tabular}{|c|c|c|c|c|c|c|}
\hline \multirow[b]{2}{*}{ Isotope } & \multirow[b]{2}{*}{$\begin{array}{l}\text { Sample No. } \\
\text { for Worth } \\
\text { Measurement }\end{array}$} & \multicolumn{2}{|c|}{ Measurement Location } & \multicolumn{2}{|c|}{$\begin{array}{c}\text { Absorption-to-Fission } \\
\text { Ratio }(1+\alpha)\end{array}$} & \multirow[b]{2}{*}{$\begin{array}{c}\text { Calculational } \\
\text { Bias, } \\
\text { C/E }\end{array}$} \\
\hline & & $\begin{array}{l}\text { Matrix } \\
\text { Row/Col. }\end{array}$ & $\begin{array}{l}\text { Radial } \\
\text { Position } \\
\quad(\mathrm{cm})\end{array}$ & $\begin{array}{l}\text { Thin-Sample } \\
\text { Measurement }\end{array}$ & $\begin{array}{l}\text { Calculated } \\
\text { for Dilute } \\
\text { Sample }\end{array}$ & \\
\hline $\mathrm{U}-233$ & $\mathrm{U}-233-3$ & $23 / 23$ & 0.00 & $1.086 \pm 0.051$ & 1.0928 & $1.006 \pm 0.051$ \\
\hline \multirow[t]{3}{*}{$\mathrm{U}-235$} & $\mathrm{MB}-21$ & $23 / 23$ & 0.00 & $1.297 \pm 0.037$ & 1.2841 & $0.990 \pm 0.028$ \\
\hline & $\mathrm{MB}-21$ & $23 / 24$ & 5.52 & $1.326 \pm 0.038$ & 1.2841 & $0.968 \pm 0.028$ \\
\hline & $M B-21$ & $23 / 2 \epsilon$ & 16.57 & $1.312 \pm 0.037$ & 1.2837 & $0.978 \pm 0.028$ \\
\hline \multirow[t]{2}{*}{$\mathrm{U}-238$} & $M B-25$ & $23 / 2 \Xi$ & 0.00 & $6.737 \pm 0.107$ & 6.8581 & $1.018 \pm 0.016$ \\
\hline & $\mathrm{MB}-25$ & $23 / 26$ & 16.57 & $6.727 \pm 0.096$ & 6.7719 & $1.007 \pm 0.014$ \\
\hline \multirow[t]{3}{*}{$\mathrm{Pu}-239$} & $\mathrm{MB}-1.0$ & $23 / 23$ & 0.00 & $1.272 \pm 0.039$ & 1.2552 & $0.987 \pm 0.029$ \\
\hline & $M B-10$ & $23 / 24$ & 5.52 & $1.304 \pm 0.040$ & 1.2551 & $0.962 \pm 0.029$ \\
\hline & $M B-10$ & $23 / 26$ & 16.57 & $1.309 \pm 0.039$ & 1.2541 & $0.958 \pm 0.029$ \\
\hline \multirow[t]{4}{*}{. } & MB-10 & $23 / 28$ & 27.62 & $1.335 \pm 0.039$ & 1.2519 & $0.938 \pm 0.029$ \\
\hline & $M B-10$ & $23 / 30$ & 38.67 & $1.303 \pm 0.042$ & 1.2468 & $0.957 \pm 0.029$ \\
\hline & $\mathrm{MB}-10$ & $23 / 33$ & 55.24 & $1.264 \pm 0.038$ & 1.2333 & $0.976 \pm 0.030$ \\
\hline & MB-10 & $23 / 35$ & 66.29 & $1.313 \pm 0.051$ & 1.2476 & $.0 .950 \pm 0.040$ \\
\hline $\mathrm{Pu}-240$ & $\mathrm{Pu}-240-2 \mathrm{D}$ & $23 / 23$ & 0.00 & $2.080 \pm 0.078$ & 2.1580 & $1.038 \pm 0.039$ \\
\hline
\end{tabular}




\subsection{CENTRAL CONVERSION RATIO}

The point conversion ratio ( $\mathrm{CRp}$ ) expresses the fissile production to fissile loss ratio in a localized region with an assumed uniform composition. A core-center conversion ratio measurement was obtained by ANL through combining the results of the thin-sample $(1+\alpha)$ experiments and the measurements of the in-plate, cel1-average fission ratios. A corresponding CRp evaluation was derived using components given by the GA calculations for cell in-plate fission and absorption rates. Table 8-2 compares the ANL measured values and corresponding GA calculated values for the various component isotopic reactions. The adjusted measurements quoted by ANL are actualy their calculated in-plate, cell-average values divided by the C/E values obtained on their analysis of the thin-sample measurements. The calculational biases ( $C / E$ values) given by the GA analyses for the absorption-to-fission and the fission ratios are very close to the same biases of the ANL study.

The available measured parameters provide for two different formulations of the central-point conversion ratio: one involves the measured in-plate U-238 capture to $\mathrm{Pu}-239$ fission ratio, and the other depends on the $\alpha$ measured for $\mathrm{U}-238$ and the $\mathrm{U}-238 / \mathrm{Pu}-239$ fission ratio. Table 8-3 defines the formula used for the CRp determinations by both methods. Also given are comparisons of calculated and measured factors and the associated $\mathrm{C} / \mathrm{E}$ biases.

Thus, for the central conversion ratio experimental determination, there are two choices for the so-called bottom line, CRp and CRp', which differ by $15 \%$. At present, it is not apparent which of the evaluations is the more accurate. The more faviorable ratio, $\mathrm{CRp}^{-}=0.767$ with the $\mathrm{C} / \mathrm{E}$ of 0.98 , is known to involve a number of uncertainties due to the assumed interpolation from the thin-sample environment (for worth measurements and fission chamber measurements using U-238) to the capture rates in the fuel fertile plates. The discrepancy between the two experimental methods calls 
TABLE 8-2

COMPONENT REACTIONS FOR CENTRAL CONVERSION RATIO EVALUATION

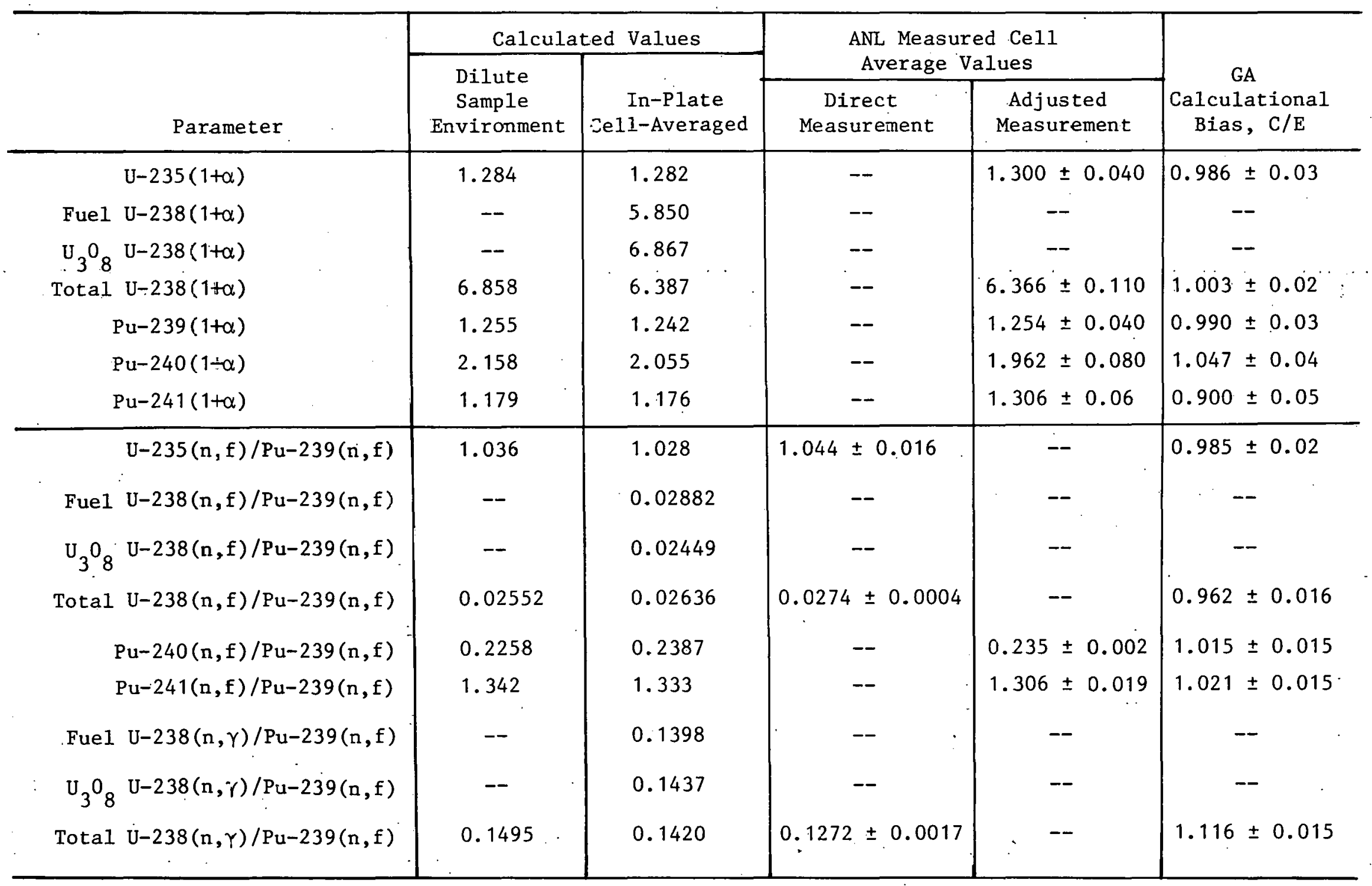


TABLE $8-3$

EVALUATION OF POINT CONVERSION RATIO AT CENTER OF CORE IN PHASE III GCFR CRITICAL ASSEMBLY

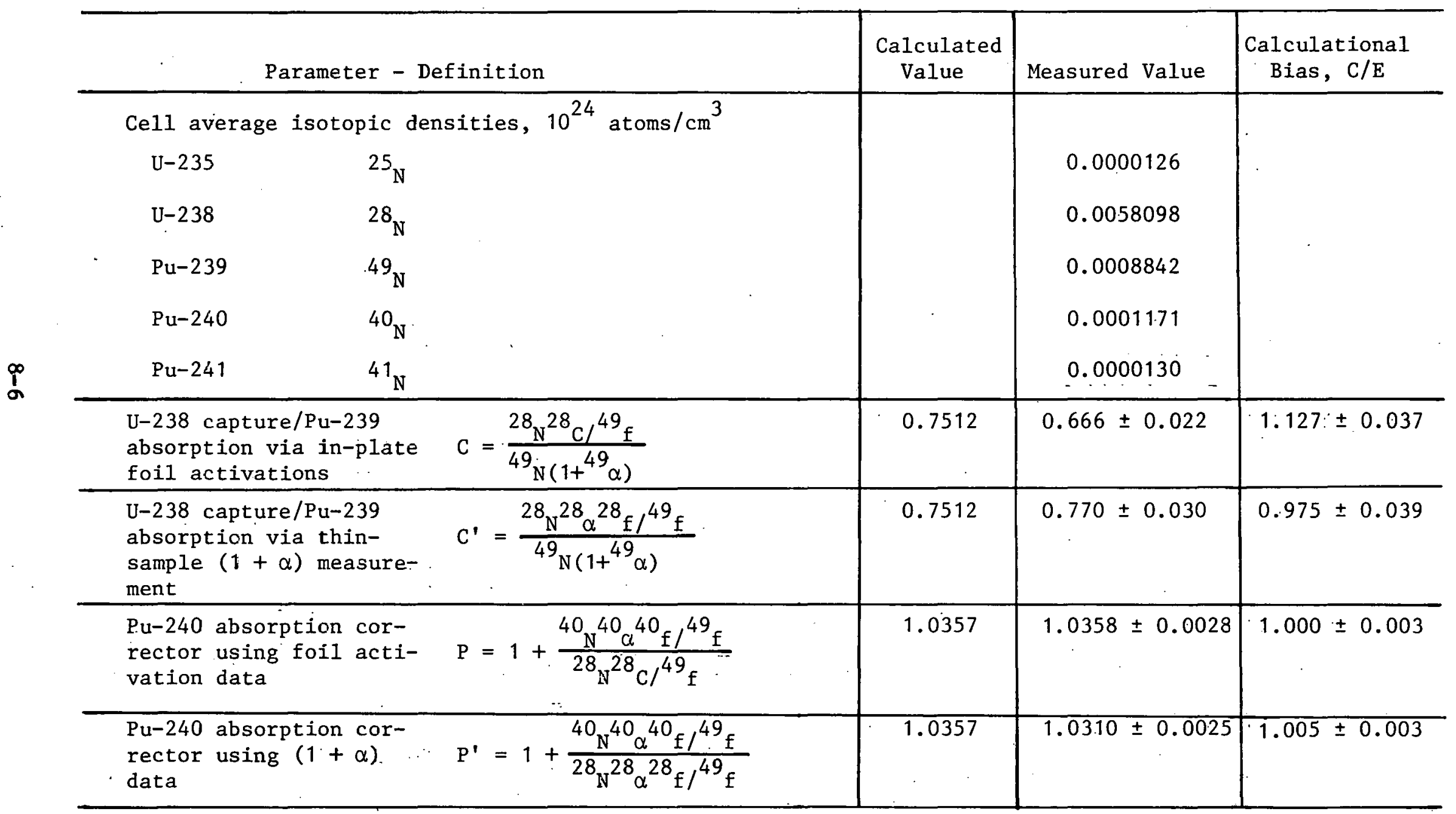


TABLE 8-3 (Continued)

\begin{tabular}{|c|c|c|c|}
\hline Parameter - Definition & $\begin{array}{l}\text { Calculated } \\
\text { Value }\end{array}$ & Measured Value & $\begin{array}{l}\text { Calculational } \\
\text { Bias, C/E }\end{array}$ \\
\hline 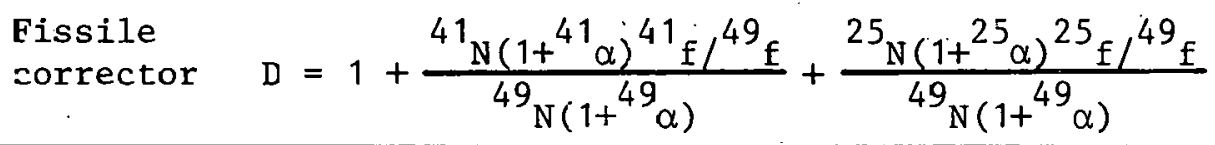 & 1.0337 & $1.0352 \pm 0.0021$ & $0.999 \pm 0.002$ \\
\hline $\begin{array}{l}\text { Jentral point conversion ratio } \quad \mathrm{CR}_{\mathrm{P}}=\mathrm{CP} / \mathrm{D} \\
\text {-1sing foil activation data }\end{array}$ & 0.7527 & $0.667 \pm 0.022$ & $1.129 \pm 0.037$ \\
\hline $\begin{array}{l}\text { Dentral point conversion ratio } \mathrm{CR}^{\prime}{ }_{\mathrm{p}}=\mathrm{C}^{\prime} \mathrm{P}^{\prime} / \mathrm{D} \\
\text { using }(1+\alpha) \text { data }\end{array}$ & 0.7527 & $0.767 \pm 0.030$ & $0.981 \pm 0.039$ \\
\hline
\end{tabular}


for further study; the capture-rate measuring technique should be calibrated against a radiochemical analysis. 


\section{PIN ZONE SUBSTITUTION EXPERIMENT}

\subsection{PIN ZONE SPECIFICATIONS}

Figures 2-2(a) and 2-2(b) illustrate the change of cell structure involved in the pin-for-plate exchange experiment carried out in a central. region of the zone 1 core and axial blankets. Pin-for-plate experiments have been routinely carried out on LMFBR mockups wherein the calandrias are sealed sodium-filled boxes with 16 tube channels for insertion of clad fuel pins or $\mathrm{UO}_{2}$ pellets. The inventory of non-sodium-filled calandrias used for sodium-voiding studies was conveniently adopted as the structural matrix for the fuel pins in this GCFR zone representation. Special voided calandrias were also procured to enable convenient installation of $\mathrm{CH}_{2}$ foam into the voids surrounding the pin channels to simulate steam flooding.

Figure $9-1$ is an outline of core zone 1 showing the subregions loaded with the normal and special voided calandrias during the pin-zone experiment. The assembly $\mathrm{RZ}$ model based on this configuration, used for the 2DB calculations for the experiment, is included in the Appendix (Fig. A-3). Also in the Appendix, the compositions of the pin-loaded special and normal calandrias are compared with the compositions of the corresponding core or blanket zone 1 plate drawer loadings.

\subsection{PIN ZONE SUBSTITUTION WORTH COMPONENTS}

The measured worth of the total exchange of pin-loaded calandrias for plate-loaded drawers in the pin zone outlined in Fig. 9-1, both core and axial blanket, as derived from Table 2-2 data, is $-31.7 \pm 2.8$ Ih. The pinfor-plate substitution worth is thus defined for the innermost $17 \%$ fraction of the core, and a total core exchange would be worth at most six times the zone worth, or about -200 Ih $(60 k)$. 


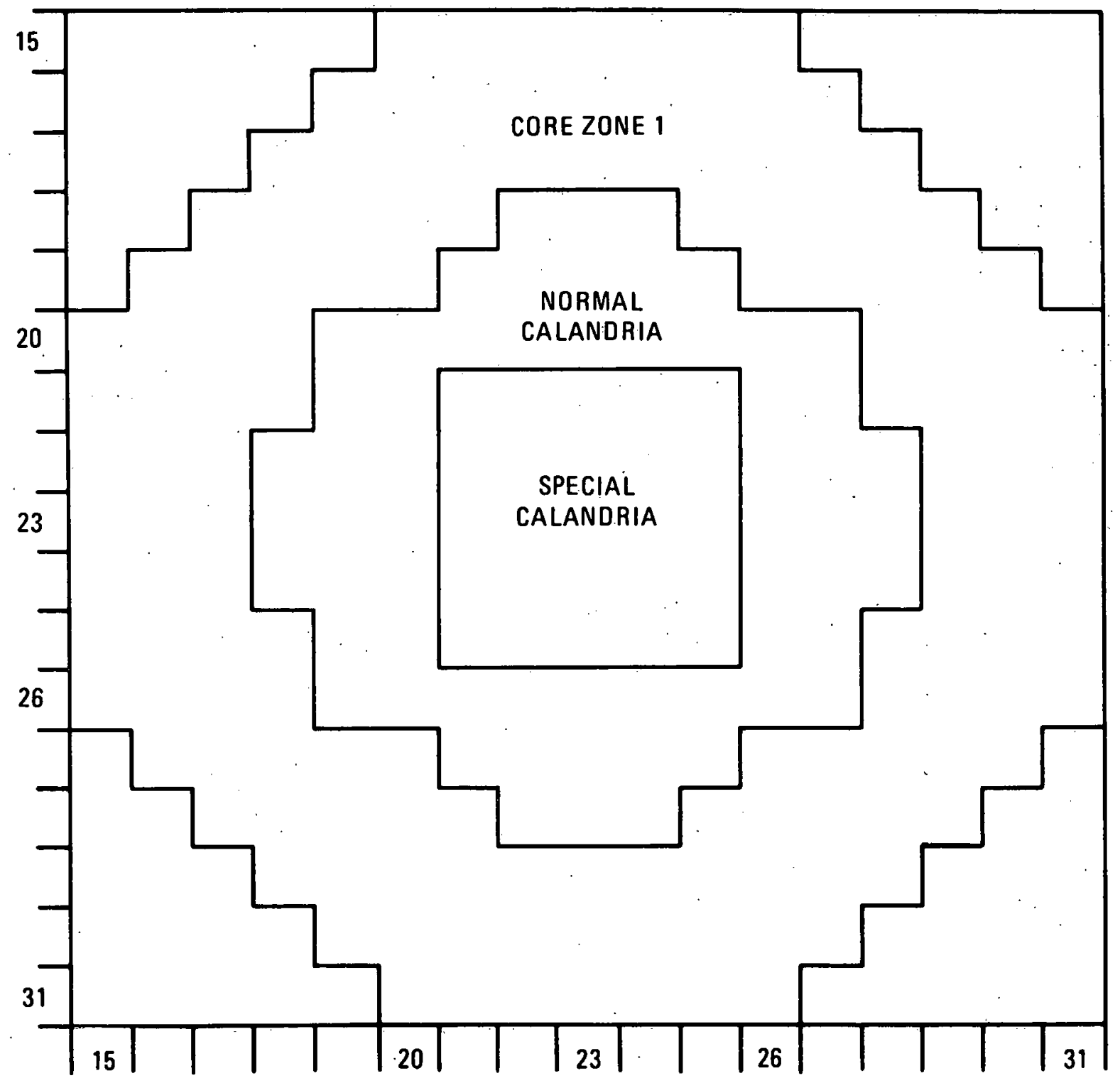

Fig. 9-1. Core configuration for GCFR Phase III pin zone assembly 
The calculations for the pin zone substitution worth were carried out in several steps to investigate the contributions from the various components involved in the switch of cell types. The three major differences between the pin and plate loadings were

1. A compositional change. Predominantly a different volume fraction for steel and deletion of molybdenum (in the Pu-U-Mo alloy).

2. A heterogeneity change. Less flux advantage (or self multiplication) in the fuel pins.

3. A change in neutron streaming. Reduced yoid dimensions with the pins, resulting in decreased leakage worth.

The results of the $2 \mathrm{DB}$ calculations carried out for the pin-zone analysis are summarized in Table 9-1. For all of these cases, the plate-core zone boundaries and compositions were fixed as defined by the pin-reference configuration diagram in Fig. A-3. The case variations in Table 9-1 involve only the pin-zone loading, with step-wise changes of the compooitions, cross secllons, and diftusion modifiers. The last columns of the table express the derived reactivity difference associated with specific change components.

Of specific interest in this analysis is the change of neutron-streaming effect incurred by the pin-for-plate switch. The Table 9-1 results reveal a zone streaming effect worth of $-0.084 \% \Delta k / k$ for the pin environment versus a value of $-0.250 \% \Delta \mathrm{k} / \mathrm{k}$ for the plate loading. Thus, the streaming correction for the plate GCFR critical assemblies appears to be about three times the effect for the rodded-fuel power reactor.

The net worths calculated in this analysis for the three major change components in the pin-for-plate substitution are compared in Table 9-2 with the results of the corresponding ANL analysis. It is seen that the GA and ANL composition change worths are about the same, but larger differences are 
TABLE 9-1

SUMMARY OF EIGENVALUE CALCULATIONS" US.ING TWO-DIMENSIONAL DIFFUSION

THEORY FOR PIN ZONE CONFIGURATION IN PHASE III GCFR ASSEMBLY

\begin{tabular}{|c|c|c|c|c|c|c|c|}
\hline \multirow[b]{2}{*}{$\begin{array}{l}2 \mathrm{DB} \\
\text { Case } \\
\text { No. }\end{array}$} & \multicolumn{3}{|c|}{$\begin{array}{l}\text { Parameter Variations for } \\
\text { Content of Core and Blanket } \\
\text { Central Calandria Zones }(a)\end{array}$} & \multirow[b]{2}{*}{$\begin{array}{c}2 \mathrm{DB} \\
\text { Calculated } \\
\text { (RZ Geometry) }\end{array}$} & \multicolumn{3}{|c|}{ Differential Worth Evaluations } \\
\hline & $\begin{array}{l}\text { Cell Atom } \\
\text { Densities }\end{array}$ & $\begin{array}{l}\text { Cell Cross } \\
\text { Sections }\end{array}$ & $\begin{array}{l}\text { Diffusion } \\
\text { Coefficient } \\
\text { Modifiers }\end{array}$ & & $\begin{array}{l}\text { Cases } \\
\text { Compared } \\
\mathrm{a} / \mathrm{b}\end{array}$ & $\left(\frac{1}{k_{b}}-\frac{1}{k_{a}}\right)$ & $\begin{array}{c}\text { Characteristics } \\
\text { Worth Effect }\end{array}$ \\
\hline 7 & Plate & Plate & Plate & 0.98801 & $11 / 7$ & +0.00030 & Total pin-for-plate \\
\hline 8 & Plate & Plate & None ${ }^{(b)}$ & 0.99046 & $7 / 8$ & -0.00250 & Plate-zone streaming \\
\hline 9 & Pin & Plate & Plate & 0.98960 & $9 / 7$ & +0.00163 & Plate-to-pin densities \\
\hline 10 & Pin & Pin & Plate & 0.98667 & $10 / 9$ & -0.00300 & Plate-to-pin heterogeneity \\
\hline 11 & Pin & Pin & Pin & 0.98830 & $11 / 10$ & +0.00167 & Plate-to-pin streaming \\
\hline 12 & Pin & Pin & None & 0.98912 & $11 / 12$ & -0.00084 & Pin-zone streaming \\
\hline
\end{tabular}

(a) Normal plate cell densities, cross sections, and diffusion modifiers used throughout the other core and blanket regions. Core radius $=70.46 \mathrm{~cm}$.

(b) Modifiers $=1.00$ to effect isotropic diffusion coefficients as determined for densities and cross-section mixtures. 
TABLE 9-2

COMPONENTS OF REACTIVITY EFFECT FOR EXCHANGE OF PIN FUEL FOR PLATE FUEL IN A C $\Xi N T R A L$ ZONE OF PHASE III ASSEMBLY

\begin{tabular}{|c|c|c|c|c|c|c|}
\hline \multirow{2}{*}{$\begin{array}{r}2 \mathrm{DB} \\
\text { Case } \\
\text { No. }\end{array}$} & \multirow{2}{*}{$\begin{array}{l}\text { Characteristic } \\
\text { Evaluated For } \\
\text { Calandria Zone }\end{array}$} & \multicolumn{2}{|c|}{$\begin{array}{r}\text { ANL Worth } \\
\text { Dete=minations (Ih) }\end{array}$} & \multicolumn{3}{|c|}{ GA Worth Analysis (Ih) } \\
\hline & & Calculated & Measured & $\begin{array}{l}\text { Calculated } \\
\text { Change }\end{array}$ & $\mathrm{C} / \mathrm{E}$ & $\mathrm{C}-\mathrm{E}$ \\
\hline $9 / 7$ & $\begin{array}{l}\text { Worth of plate-to-pin } \\
\text { material density changes }\end{array}$ & \pm 157.8 & - & +152.2 & -- & -- \\
\hline $10 / 9$ & $\begin{array}{l}\text { Change of heterogeneity } \\
\text { effect, plate-to-pin load }\end{array}$ & -251.0 & -- & -280.2 & & -- \\
\hline $11 / 10$ & $\begin{array}{l}\text { Change in streaming } \\
\text { effect, plate-to-pin }\end{array}$ & +122.6 & -- & +156.0 & -- & -- \\
\hline $11 / 7$ & $\begin{array}{l}\text { Total worth pin-for-plate } \\
\text { exchange }\end{array}$ & +29.4 & $-31.7 \pm 2.8$ & +28.0 & -0.88 & $59.7 \pm 2.8$ \\
\hline
\end{tabular}


obtained for heterogeneity and streaming effects. On balance, the net worths for the zone substitution are calculated the same by GA and ANL, both positive and about +60 Ih different from the measured worth of $-32 \mathrm{Ih}$. The calculational discrepancy is disappointing but not unreasonably excessive considering that the total effect arises from net positive and negative components of +308 and $-280 \mathrm{Ih}$, respectively, with probable errors on the order of $\pm 10 \%$ per component, compounded.

The reference plate-loaded-configuration reactivity was not actually measured but was inferred from that of larger core configuration with the use of the measured edge-drawer worth. The applied core-size correction of -148 Ih could be in error as much as 20 Ih due to asymmetric geometry and reloading considerations. Also, in the experiments, molybdenum shims could have been loaded with the core calandria to reduce the plate-to-pin compositional differences.

In Table 9-2, the +152 Ih composition effect is predominantly due to the changes (plate-to-pin) in the core molybdenum and oxygen densities, with about +94 Ih from the deletion of the molybdenum and +39 Ih from the decreased oxygen content. Based on central-worth discrepancies for these two materials, an uncertainty on the order of \pm 40 Ih could easily be assigned for the evaluation of the worth of the plate-to-pin material changes.

Thus, attempts to compare the validities of the heterogeneity and streaming-effect treatments for the pin loadings versus the plate loadings is overshadowed by the uncertainties in the measurements and compositional effects. A repeat of these pin studies will be requied in the future GCFR critical experiment program, with more detailed studies of the compositional effects via distributed worth measurements for molybdenum, steel, oxygen, and fuel. 


\subsection{AXIAL FISSION-RATE PROFILE IN PIN ZONE}

The axial distribution of Pu-239 fission rate in the fuel pins of the central calandria was measured by activation of plutonium folls placed between the ends of special $7.6-\mathrm{cm}$ (3-in.) $\mathrm{PuO}_{2}$ pins inserted in one of the central tubes. The foils were analyzed in the same manner as for the plate-core foil irradiations. Calculation of the $\mathrm{Pu}-239$ fission-rate profile was accomplished with a PERT run using the $Z$ axis ten-group flux distributions from the pin-loaded 2DB reference case and in-pin $\mathrm{Pu}-239$ cross sections (plus correction for the relative fission contribution from the foil 5\% Pu-240 content). Figure 9-2 compares the measured and calculated Pu-239 fission-rate distributions along the axis of the core pin zone.

The calculated fission-rate distribution axially through the pin zone is seen in Fig. 9-2 to deviate from the measurements more significantly than for the corresponding analysis in the plate-loaded core (Fig. 7-6). The discrepancy indicates that the axial streaming correction factors are probably underestimated in this analysis. This could have come about from the modeling of the PINDF 3 case for the pin cell wherein the per-pin allocatiuis of calandrla-box wall and matrix steel were smeared into the void channel.

\subsection{FOIL ACTIVATIONS FOR REACTION RATIOS IN FUEL PINS}

Foils of enriched uranium, depleted uranium, and plutonium were irradiated between the ends of the core fuel pins and the blanket $\mathrm{UO}_{2}$ pins of the central matrix unit calandria loadings. The in-pin fission and capture ratios, on a per-atom basis for the involved isotopes, obtained in this exper1ment are given in Table 9-3. Calculated values and calculated-to-experimental ratios comparable to thcse pin-zone results are included in Table $9-3$, as are the corresponding results of the plate-zone analysis. In all cases, the discrepancies of the pin-zone analyses are greater than those for the plate-zone calculated data. A 


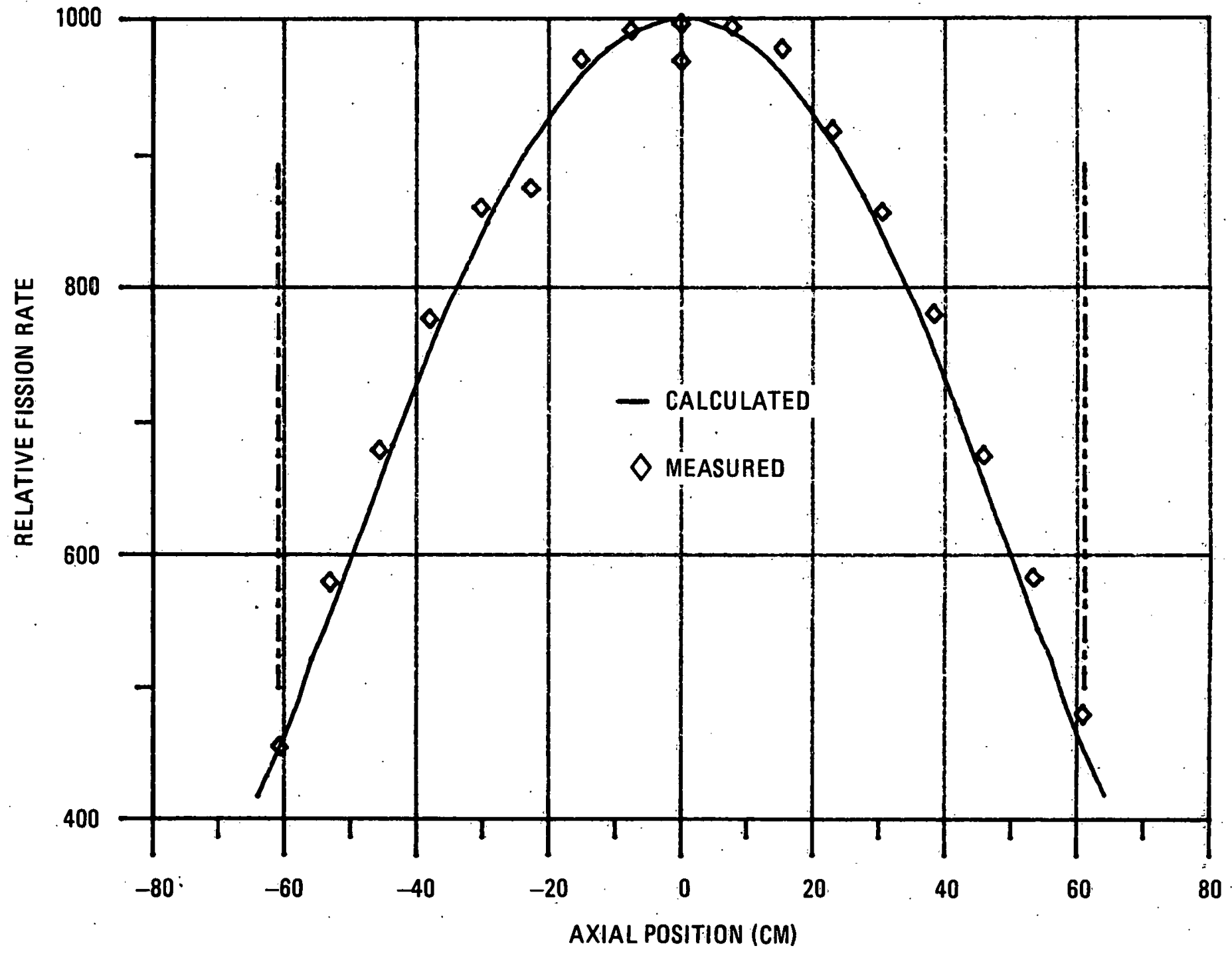

Fig. 9-2. Pu-239 axial fission rate profile in pin zone 
TABLE 9-3

COMPARISON OF CELL AVERAGE FUEL REACTION RATIOS MEASURED IN PIN-LOADED ASSEMBLY WITH CALCULATED RATIOS

\begin{tabular}{|c|c|c|c|c|c|c|}
\hline \multirow[b]{3}{*}{$\begin{array}{l}\text { Reactor } \\
\text { Region }\end{array}$} & \multirow[b]{3}{*}{$\begin{array}{c}\text { Reaction } \\
\text { Ratio }\end{array}$} & \multicolumn{3}{|c|}{ Pin-Loaded Zone } & \multirow{2}{*}{\multicolumn{2}{|c|}{ Plate Loading }} \\
\hline & & \multirow[b]{2}{*}{$\begin{array}{l}\text { Measured } \\
\text { Value }\end{array}$} & \multirow[b]{2}{*}{$\begin{array}{l}\text { Calculated } \\
\text { Value }\end{array}$} & \multirow[b]{2}{*}{$\begin{array}{c}C / E \\
( \pm 0.018)\end{array}$} & & \\
\hline & & & & & $\begin{array}{l}\text { Calculated } \\
\text { Value }\end{array}$ & $\begin{array}{c}C / E \\
( \pm 0.018)\end{array}$ \\
\hline Core $e^{(a)}$ & F5/F9 & $1.056 \pm 0.014$ & 1.0257 & 0.971 & 1.0278 & 0.984 \\
\hline & F8/F9 & $0.02791 \pm 0.0003$ & 0.02618 & 0.938 & 0.02636 & 0.962 \\
\hline & $\mathrm{C} 8 / \mathrm{F} 9$ & $0.1267 \pm 0.0016$ & 0.1440 & 1.136 & 0.1420 & 1.116 \\
\hline. & $\mathrm{C} 9 / \mathrm{F} 9$ & -- & 0.2466 & -- & 0.242 & -- \\
\hline & F8/F5 & $0.02643 \pm 0.0003$ & 0.02552 & 0.966 & 0.02565 & 0.978 \\
\hline & C8/F5 & $0.1200 \pm 0.0016$ & 0.1404 & 1.170 & 0.1382 & 1.134 \\
\hline $\begin{array}{l}\text { Axial } \\
\text { blanket }\end{array}$ & F8/F5 & $0.00966 \pm 0.00016$ & 0.009341 & 0.967 & 0.01382 & 1.000 \\
\hline . & $\mathrm{C} 8 / \mathrm{F} 5$ & $0.1176 \pm 0.0018$ & 0.14271 & 1.214 & 0.13818 & 1.112 \\
\hline
\end{tabular}

(a) Axial distance from core midplane of $7.6 \mathrm{~cm}$ for pin zone, $1.6 \mathrm{~cm}$ for plate loading.

(b) Axial distance from core midplane of $68.6 \mathrm{~cm}$ for pin zone, $62.7 \mathrm{~cm}$ for plate loading. 
similar correlation was obtained in the ANL analyses, but it had generally lower discrepancies ( $\mathrm{C} / \mathrm{E}$ values $\sim 2 \%$ or $3 \%$ closer to unity). Further studies are thus warranted on the heterogeneity and streaming effects for this pin lattice. 


\section{SUMMARY}

The Phase III GCFR critical assembly experiments were analyzed using methods routinely employed for GCFR power plant core design and performance predictions. In general, calculated and measured Phase III parameters have agreed well, and thus, substantiated the physics method used. Also, the results of these GA calculations using a 10-group cross-section structure, as for the GCFR core design analysis, concur well with results of ANL calculations using a more rigorous 29-group structure.

The basic nuclear data used, ENDF/B-4, perhaps combined with the methodologies, still yield biases of calculated predictions relative to measured results. In regard to the criticality determinations, the calculations yield eigenvalues that are a factor of 0.986 times experimental $k$ assessments for critical configurations involving the ZPR plate-loading heterogeniety ( $a$ bias of $-1.4 \% \Delta \mathrm{k} / \mathrm{k}$ ). The central-worth discrepancy continues to appear, but with $\mathrm{C} / \mathrm{E}$ factors like 1.12 for plutonium, which are somewhat smaller than those obtained in the previous GCFR assemblies and smaller by about $4 \%$ than the results of ANL worth calculations. A sizable discrepancy continues between the calculated and measured breeding-ratio parameters; the U-238 capture/Pu-239-fission rate ratios in the cell fuel are calculated some $13 \%$ greater than ratios derived from in-plate foil irradiation,experiments. However, these measurements are in confict with results of another type of experiment, somewhat less rigorous, which determines the isotopic capture-to-fission ratio for U-238. There should be a high priority effort in the reexamination of the experimental technique used for the U-238 capture/Pu-239-fission ratio, with a definitive intercalibration against radiochemical techniques.

Calculated and measured fission and capture rate spatial distributions have been found to agree quite well, indicating that the power density 
profiles in the core can be calculated to an accuracy of about $3 \%$ (deviation at core/blanket boundary with central normalization). There are some indications that the diffusion modifers ușed (to represent streaming in coolant channels) underestimate leakage in the direction perpendicular to the plate alignments in the ZPR critical assembly. Higher leakage terms could improve the flux and reaction-rate profile calculations, but also would increase the eigenvalue bias to probably $-1.8 \%$.

A discrepancy in the pin-for-plate fuel cell substitution worth prediction indicates that some further examination of heterogeneity and streaming effect accounting is needed. The pin zone experiment indicated that the calculational bias for eigenvalue of a rodded fuel reactor would be somewhat higher than the 0.986 factor obtained for the reference Phase III plate configuration. The consistency between methods used for these studies and for rodded fuel assembly core calculations will have to be verified to better assess the eigenvalue bias of the GCFR design calculations. 


\section{REFEKENCES}

1. Moore, R. A., "A Critical Experiment Program for the $300 \mathrm{MW}(\mathrm{e})$ Gas-Cooled Breeder Reactor - Scope and Purpose." USAEC Report Gulf-GAAl2780, General Atomic Company, October 1973.

2. Bhattacharyya, S. K., "An Experimental Study of the Neutronics of the First Gas-Cooled Fast Reactor Benchmark Assembly (GCFR Phase I Assembly)," ERDA Report ANL-7636, Argonne National Laboratory, December 1976.

3. "Reactor Physics Studies in the GCFR Phase II Critical Assembly," R. B. Pond (ed.), ERDA Report ANL-76-108, Argonne National Laboratory, September 1976.

4. Bhattacharyya, S. K., "Reactor Physics Studies in the Stream Flooded GCFR Phase-II Critical Assembly," DOE Report ANL-78-83, Argonne National Laboratory, August 1978 .

5. Hess, A. L., and R. A. Rucker, "Analysis of Full Core Steam Flooding Experiments for the Phase-II GCFR Critical Assembly," DOE Report GA14834, General Atomic Company, May 1978.

6. "Reactor Physics Studies in the GCFR Phase III Critical Assembly," J. A. Morman (ed.), DOE Repurt ANL-79-35, Argonne National Laboratory, March 1980.

7. Garber, D., "ENDF/B Summary Documentation" (ENDF-201, 2nd ed.), ERDA Report BNL-17541, Brookhaven National Laboratory, October 1975.

8. Merril1, M. H., "Nuclear Design Methods and Experimental Data in Use at Gulf General Atomic," General Atomic Report Gulf-GA-Al2652, July 1973.

9. Mathews, D. R., et al., "GGC-5, A Computer Program for Calculating Neutron Spectra and Group Constants," General Atomic Report GA-8871, September 1971.

10. Archibald, R. J., and D. R. Mathews, "The GAF/GAF/BAND Fast Reactor Cross Section Preparation System, Vo1. II, GAND2 and GFE2, Computer Programs for Preparing Input Data for the GARGAR, GGC, and MICROX Codes 
from an ENDF/B Format Nuclear Data File," USAEC Report GA-7542, General Atomic Company, March 1973.

11. Mathews, D. R., and P. K. Koch, "GANDY3, A Computer Program for the Evaluation of Effective Cross Sections, in the Unresolved Resonance Region," USAEC Report GA-A12826, General Atomic Company, January 28, 1974 .

12. Archibald, R., K. D. Lathrop, and D. R. Mathews, "1DFX-A Revised Version of the 1DF (DTF-IV) SN Transport Theory Code," General Atomic Report Gulf-GA-B10820, September 1971.

13. Lathrop, K. D., and B. G. Carlson, "Discrete Ordinates Angular Quadrature of the Neutron Transport Equation," Los Alamos Scientific Laboratory Report LA-3186, 1965.

14. Benoist, P., "Streaming Effects and Collision Probabilities in Lattices," Nuc1. Sci. Eng. 34, 285 (1968).

15.., Kier, P., Argonne National Laboratory, private communication.

16. Mathews, D. R., "PINDF3 Input Manual," General Atomic Company unpublished data.

17. Little, W. W., Jr., and R. W. Hardie, "2DB. User's Manual - Revision 1," Pacific Northwest Laboratory Report BNWL-831, Rev. 1, 1969.

18. Hardie, R. W., and W. W. Little, Jr., "PERT-V, A Two-Dimensional Perturbation Code for Fast Reactor Analysis," Pacific Northwest Laboratory Report BNWL-1161, September 1969.

19. Bretscher, M. M., and W. C. Redman, "Low Flux Measurements of Pu-239 and U-235 Capture-to-Fission Ratios in a Fast Reactor Spectrum," Nuc1. Sci. Eng. 39, 368 (1970). 


\section{APPENDIX}

\section{A.1. DETAILS OF PHASE III REFERENCE MODELS}

Figures $\mathrm{A}-1$ and $\mathrm{A}-2$ show the $\mathrm{RX}-$ and $\mathrm{XY}$-geometry models, respectively, of the plate-core reference configuration employed in the 2DB, two-dimcnsional diffusion theory calculations. Figure A-3 defines the RZ model for the reference configuration with the central zone loadings of the pin core and blankets. Core region compositions for all of the cases are included in Table A-1, while Table A-2 lists the compositions for the blanket and reflector regions.

A.2. GGC-5 SPECIFICATIONS FOR GENERATION OF CROSS SECTIONS FOR PLATE-LOADED CORE ZONES 1 AND 3 AND FOR PIN CORE AND BLANKET

Table A-3 lists the material compositions input to the GGC-5 problems run for this Phase III analysis. The appendix of the Phase II steam report (Ref. 5) contains similar specifications for the GGC-5 cases for cross sections utilized in core zone 2 and the normal plate radial blanket, axial blanket, and reflectors. Table A-3 also gives the two-region cell details for the GAROL resolved resonance range calculation and the one-group average parameters edited by the code.

\section{A.3. SPECIFICATIONS OF CELL HETEROGENEITY CALCULATIONS}

The DTFX slab geometry model for the core zone 1 plate drawer loading is described in Table A-4. Due to the symmetric material loading in the drawer [Fig. 2.2(a)], only a half-drawer cell arrangement was required with the specification of reflective boundaries on both sides. Axial leakage for the cells was represented in the DTFX runs by adding a pseudo-absorber cross section by group ( $\mathrm{a} \mathrm{DB}^{2}$ value) uniform1y across the cell: the groupwise buckling $\left(\mathrm{B}^{2}\right)$ terms were derived from early 2DB calculations and the $D$ 


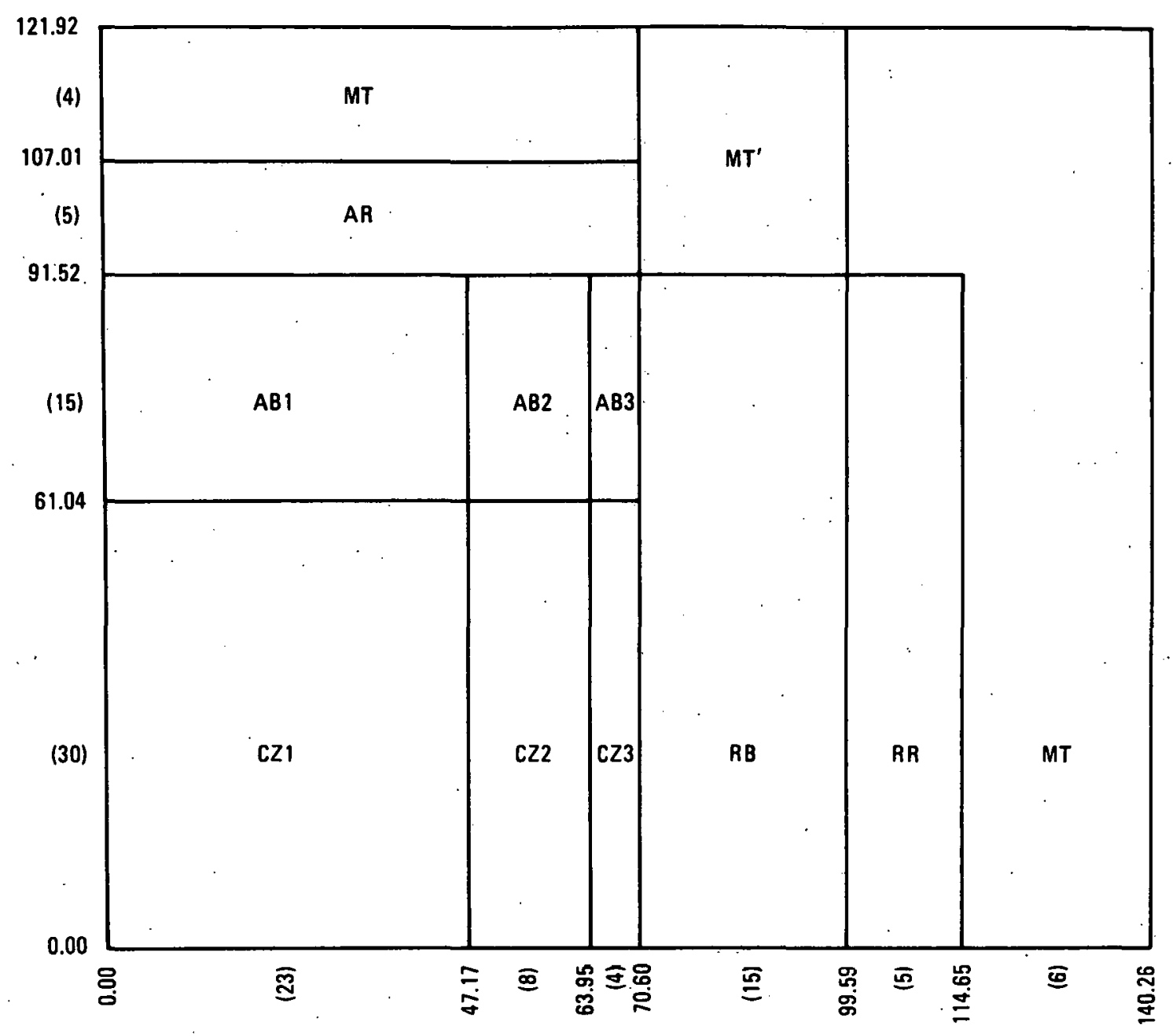

Fig. A-1. RZ calculational model of the GCFR Phase III plate reference assembly. 


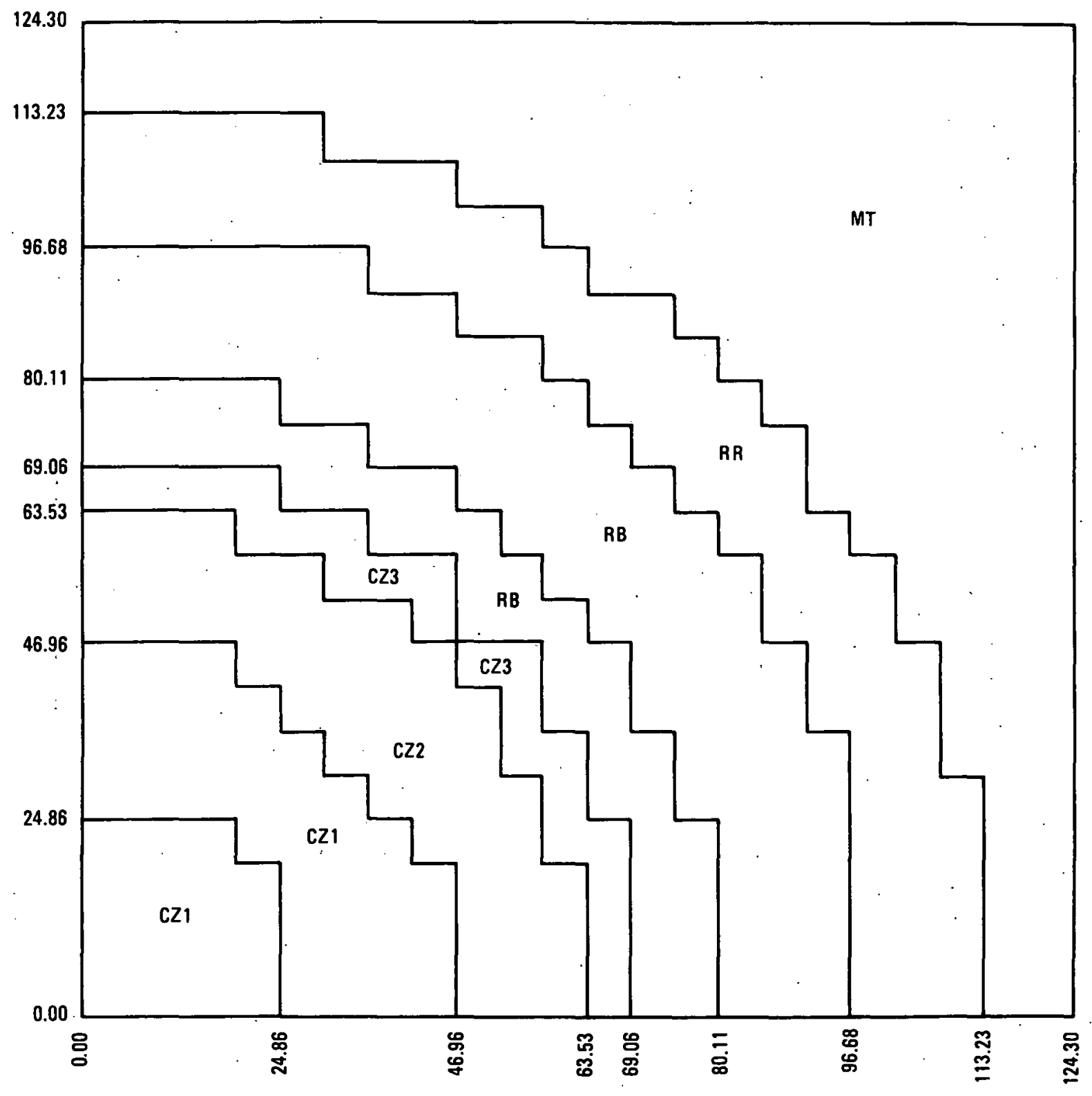

Fig. A-2. XY calculational model of the reference configuration 


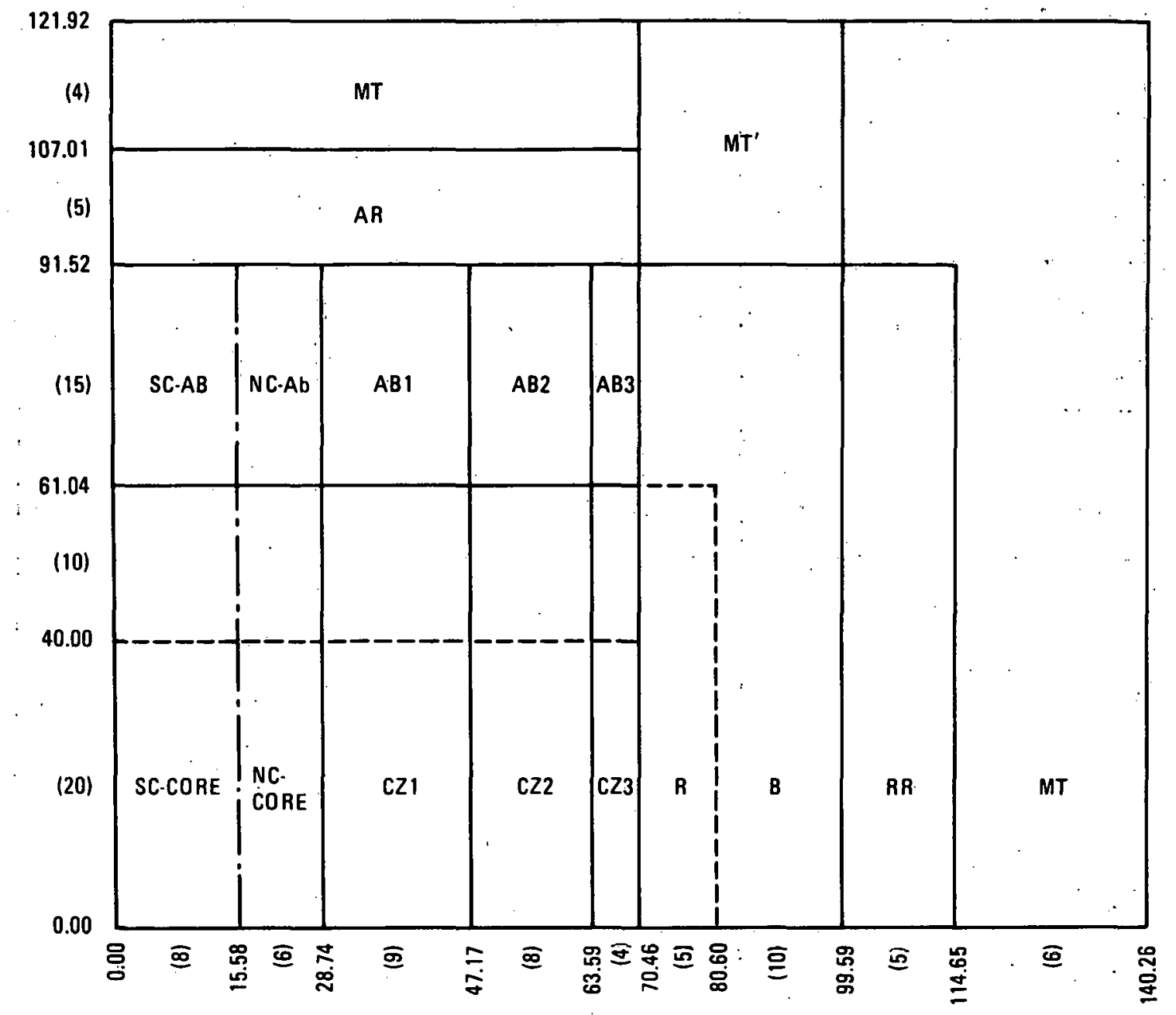

F1g. A-3. RZ calculational model of the GCFR Phase III pin zone assembly 
TABLE A-1

CORE REGION COMPOSITIONS USED IN ANALYTICAL MODELS

FOR PHASE III GCFR CRITICAL ASSEMBLY

\begin{tabular}{|c|c|c|c|c|c|}
\hline \multirow[b]{4}{*}{ Isotope } & \multicolumn{5}{|c|}{ Region Atom Densities $\left(10^{21}\right.$ atoms $\left./ \mathrm{cm}^{3}\right)$} \\
\hline & \multirow{2}{*}{\multicolumn{3}{|c|}{$\begin{array}{l}\text { Reference Configuration Core } \\
\text { (Plate Loadings) }\end{array}$}} & \multirow{3}{*}{$\begin{array}{c}\text { Pin Zone } \\
\text { Special } \\
\text { Calandria, } \\
\text { Core }\end{array}$} & \multirow{3}{*}{$\begin{array}{c}\text { Experiment } \\
\text { Normal } \\
\text { Calandria } \\
\text { Core }\end{array}$} \\
\hline & & & & & \\
\hline & Zone 1 & Zone 2 & Zone 3 & & \\
\hline 0 & 14.8674 & 13.8595 & 11.8173 & 14.201 & 14.1450 \\
\hline $\mathrm{Cr}$ & 2.6337 & 2.8669 & 3.1381 & 3.540 & 3.4870 \\
\hline $\mathrm{Mn}$ & 0.2107 & 0.2291 & 0.2515 & 0.2596 & 0.2413 \\
\hline $\mathrm{Fe}$ & 13.2544 & 15.3744 & 18.9341 & 12.4910 & 12.2260 \\
\hline $\mathrm{Ni}$ & 1.2056 & 1.3240 & 1.4606 & 1.5930 & 1.5890 \\
\hline Mo & 0.2258 & 0.3022 & 0.4521 & -- & -- \\
\hline $\mathrm{U}-235$ & 0.0126 & 0.0122 & 0.0111 & 0.0132 & 0.0132 \\
\hline$U-238-P^{(a)}$ & 2.5070 & 3.3413 & 4.9782 & 5.8190 & 5.8190 \\
\hline $\mathrm{U}-238-0^{(\mathrm{b})}$ & 3.3028 & 2.2010 & -- & -- & -- \\
\hline $\mathrm{Pu}-238$ & 0.0006 & 0.0007 & 0.0008 & 0.0005 & 0.0005 \\
\hline $\mathrm{Pu}-239$ & 0.8842 & 1.1832 & 1.7718 & 0.8836 & 0.8836 \\
\hline $\mathrm{Pu}-240$ & 0.1171 & 0.1569 & 0.2351 & 0.1177 & 0.1177 \\
\hline $\mathrm{Pu}-241^{\text {(c) }}$ & 0.0130 & 0.0163 & 0.0227 & 0.0144 & 0.0144 \\
\hline $\mathrm{Pu}-242$ & 0.0019 & 0.0024 & 0.0032 & 0.0020 & 0.0020 \\
\hline$A m-241^{(c)}$ & 0.0052 & 0.0094 & 0.0178 & 0.0113 & 0.0113 \\
\hline $\begin{array}{l}\text { Region } \\
\text { label (d) }\end{array}$ & $\mathrm{CZ} 1$ & CZ2 & .7 .3 & SS-core & NC-core \\
\hline
\end{tabular}

(a) Contribution from Pu-U-Mo alloy plates in plate loading or from mixed-oxide $\left(\mathrm{PuO}_{2}-\mathrm{UO}_{2}\right)$ pins in pin loading.

(b) Contribution from $\mathrm{U}_{3} \mathrm{O}_{8}$ plates.

(c) Decay evaluation as of July 1, 1975.

${ }^{\text {(d) }}$ As used in model diagrams, Figs. A-1, A-2, and A-3. 
TABLE A-2

COMPOSITIONS FOR BLANKET AND REFLECTOR REGIONS OF PHASE III GCFR ASSEMBLY

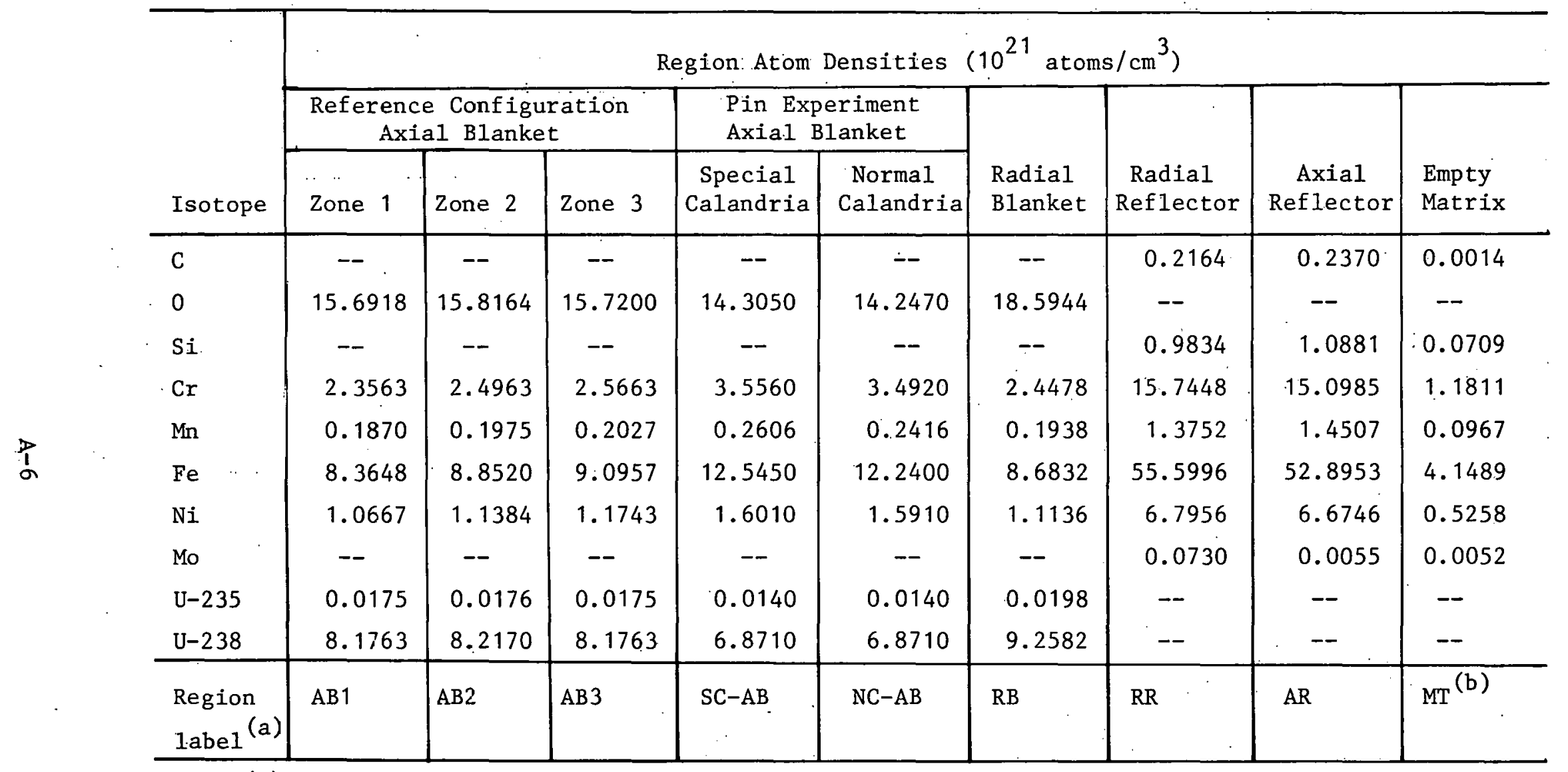

(a) As indicated on model diagrams in Figs. A-1, A-2, and A-3.

(b) Empty matrix tube: for $\mathrm{MT}^{\prime}$ (empty drawer in tube) densities are $1.55 \mathrm{x}$ MT values. 
TABLE A-3

DETAILS OF GGC-5 PROBLEMS FOR GENERATING CROSS SECTIONS USED IN ANALYSIS OF PHASE III GCFR CRITICAL EXPERIMENTS

\begin{tabular}{|c|c|c|c|c|c|c|c|c|c|c|}
\hline \multirow[b]{2}{*}{$\begin{array}{l}\text { GAROL specifications } \\
\text { Region No. } \\
\text { Content }\end{array}$} & \multicolumn{2}{|c|}{$\begin{array}{c}\text { Set } \mathrm{G} \\
\text { Core Zone } 1 \mathrm{Pu}\end{array}$} & \multicolumn{2}{|c|}{$\begin{array}{l}\text { Set } \mathrm{H} \\
\text { Core Zone } 1 \quad \mathrm{U}_{3}{ }^{0} 8\end{array}$} & \multicolumn{2}{|c|}{$\begin{array}{c}\text { Set I } \\
\text { Core Zone } 3\end{array}$} & \multicolumn{2}{|c|}{$\begin{array}{c}\text { Set } \mathrm{J} \\
\text { Core Calandrla }\end{array}$} & \multicolumn{2}{|c|}{$\begin{array}{c}\text { Set } \mathrm{K} \\
\text { Blanket Calandria }\end{array}$} \\
\hline & $\begin{array}{c}1 \\
\text { Pu-U-Mo } \\
\text { plate }\end{array}$ & $\begin{array}{c}2 \\
\text { Stee } 1+ \\
\mathrm{U}_{3} \mathrm{o}_{8}\end{array}$ & $\begin{array}{l}\quad 1 \\
\mathrm{U}_{3}{ }^{0} 8 \\
\text { plate }\end{array}$ & $\begin{array}{l}2 \\
\text { Steel } \\
\text { fuel }\end{array}$ & $\begin{array}{c}1 \\
\text { Pu-U-Mo } \\
\text { plate }\end{array}$ & $\begin{array}{c}2 \\
\text { Steel }\end{array}$ & $\frac{1}{\mathrm{PuO}_{2}-\mathrm{UO}_{2}}$ & $\begin{array}{c}2 \\
\text { Steel }\end{array}$ & $\begin{array}{c}1 \\
\mathrm{u} \mathrm{O}_{2}\end{array}$ & $\begin{array}{c}2 \\
\text { Steel }\end{array}$ \\
\hline $\begin{array}{l}\text { Chord length, cm } \\
\text { Dancoff factor }\end{array}$ & $\begin{array}{l}1.0200 \\
0.0849\end{array}$ & 10.0290 & $\begin{array}{l}1.1980 \\
0.2950 \\
\end{array}$ & 4.3265 & $\begin{array}{l}1.0200 \\
0.2524 \\
\end{array}$ & 4.5045 & $\begin{array}{l}0.8586 \\
0.2545 \\
\end{array}$ & 1.9701 & $\begin{array}{l}0.8586 \\
0.3048 \\
\end{array}$ & 1.9701 \\
\hline $\begin{array}{l}\text { Dens1ty, } 10^{21} / \mathrm{cm}^{3} \\
\mathrm{Cr} \\
\mathrm{Mn} \\
\mathrm{Fe} \\
\mathrm{Ni} \\
\mathrm{Mo} \\
\mathrm{U}-235 \\
\mathrm{U}-238 \\
\mathrm{Pu}-238 \\
\mathrm{Pu}-239 \\
\mathrm{Pu}-240 \\
\mathrm{Pu}-241 \\
\mathrm{Pu}-242 \\
\mathrm{Am}-241\end{array}$ & $\begin{array}{r}2.4808 \\
0.0592 \\
27.1650 \\
0.0065 \\
9.6479 \\
1.2831 \\
0.1332 \\
0.0197 \\
0.1408\end{array}$ & $\begin{array}{r}16.3810 \\
2.9067 \\
0.2326 \\
14.6130 \\
1.3307 \\
0.0079 \\
3.6398\end{array}$ & 40.6550 & $\begin{array}{r}7.7289 \\
3.3690 \\
0.2695 \\
16.9370 \\
1.5424 \\
0.2924 \\
0.0070 \\
3.2022 \\
1.1373 \\
0.1512 \\
0.0157\end{array}$ & $\begin{array}{c}. \\
2.4808 \\
0.0592 \\
27.1650 \\
0.0065 \\
9.6749 \\
1.2831 \\
0.1332 \\
0.0197 \\
0.1408\end{array}$ & $\begin{array}{r}14.4720 \\
3.8388 \\
0.3076 \\
23.1675 \\
1.7869\end{array}$ & $\begin{array}{r}46.7862 \\
\\
\\
0.0435 \\
19.1711 \\
0.0020 \\
2.9111 \\
0.3877 \\
0.0474 \\
0.0066 \\
0.0372\end{array}$ & $\begin{array}{r}5.0828 \\
0.3727 \\
17.9347 \\
2.2873\end{array}$ & $\begin{array}{r}47.1292 \\
0.0462 \\
22.6370\end{array}$ & $\begin{array}{r}5.1058 \\
0.3742 \\
18.0123 \\
2.2987\end{array}$ \\
\hline Input buckling $\left(B^{2}\right), \mathrm{cm}^{-1}$ & $8.15 \mathrm{x}$ & $10^{-4}$ & $8.15 \times$ & $10^{-4}$ & $2.40 \mathrm{x}$ & $10^{-3}$ & $8.15 \mathrm{x}$ & $0^{-4}$ & $1.00 \mathrm{x}$ & $10^{-6}$ \\
\hline $\begin{array}{l}\text { Celi. averagé one-group } \\
\text { results } \\
\sum_{\mathrm{f}} \\
\sum_{\mathrm{libs}}-\sum_{\mathrm{n} 2 \mathrm{n}} \\
\mathrm{k}_{\text {Infinity }}{ }_{\text {Average } \mathrm{DB}^{2}} \\
\text { keff }\end{array}$ & $\begin{array}{l}0.005 \\
0.004 \\
0.171 \\
1.360 \\
0.001 \\
0.980\end{array}$ & $\begin{array}{l}575 \\
099 \\
37 \\
1 \\
585 \\
8\end{array}$ & $\begin{array}{l}0.005 \\
0.004 \\
0.171 \\
1.362 \\
0.001 \\
0.982\end{array}$ & $\begin{array}{l}584 \\
099 \\
28 \\
3 \\
586 \\
2\end{array}$ & $\begin{array}{l}0.010 \\
0.005 \\
0.171 \\
1.954 \\
0.004 \\
1.033\end{array}$ & $\begin{array}{l}243 \\
242 \\
4 n \\
0 \\
668 \\
6\end{array}$ & $\begin{array}{l}0.0056 \\
0.0040 \\
0.1708 \\
1.3714 \\
0.0015 \\
0.9876\end{array}$ & & $\begin{array}{l}5.90 \times \\
0.0031 \\
0.1927 \\
0.1902 \\
0.1900\end{array}$ & $\begin{array}{l}10^{-4} \\
03 \\
1\end{array}$ \\
\hline
\end{tabular}


TABLE A-4

SPECIFICATIONS OF SLAB CELL MODEL FOR DTFX CALCULATIONS OF CORE ZONE 1 HETEROGENEITY FACTORS

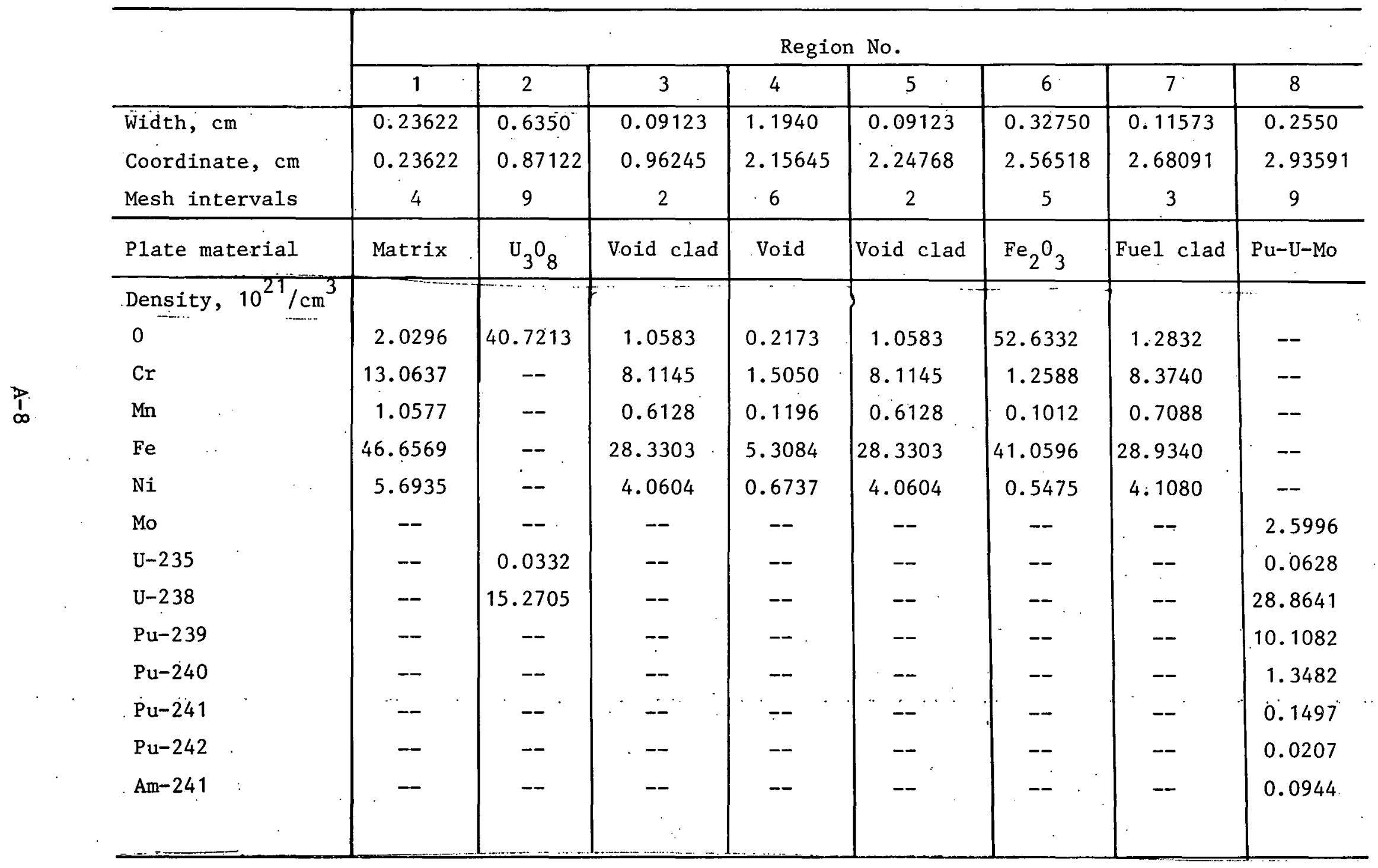


values (diffusion constants) were provided by the cell-average macroscopic transport cross sections.

Similarly, Tables A-5 and A-6 give the specifications of the slab cell model used for the DTFX problem for the zone 3 core drawer loading. The cylindrical geometry model for the pin cell core loading is described in Table A-7.

\section{A.4. RESULTS OF PERT CALCULATIONS FOR RADIAL WORTH PROFILES}

Tables A-8 and A-9 1ist the reactivity coefficients derived via the PERT code using real and adjoint fluxes from 2DB for the Phase III reference configuration. The tabulated values have been normalized to the measured central worths; i.e., the actual PERT output data have been divided by the respective material $\mathrm{C} / \mathrm{E}$ values listed in Table 5-2.

\section{A.5. CALCULATED REACTION-RATE PROFILES}

Tables A-10 and A-11 list the normalized fission and capture rate distributions for the radial and axial directions, respectively, as obtained from PERT edits of the XY- and RZ-geometry 2DB runs. The relative rates were derived with the cell average fluxes and the heterogeneous cell average cross sections, thus providing the in-plate reaction rates comparable to the in-plate foil activation data. 
TABLE A-5

GEOMETRY SPECIFICATIONS FOR DTFX MODEL OF CORE ZONE 3 PLATE CELL

\begin{tabular}{c|l|l|c|c}
\hline $\begin{array}{c}\text { Region } \\
\text { No. }\end{array}$ & $\begin{array}{c}\text { Material } \\
\text { Symbo1 }\end{array}$ & $\begin{array}{l}\text { Region } \\
\text { Width }\end{array}$ & $\begin{array}{c}\text { Coordinate } \\
(\mathrm{cm})\end{array}$ & $\begin{array}{c}\text { No. of Mesh } \\
\text { Intervals }\end{array}$ \\
\hline 1. & ST1 & 0.2362 & 0.23620 & 3 \\
2 & ST2 & 0.06993 & 0.30613 & 2 \\
3 & VOID & 0.5590 & 0.86513 & 3 \\
4 & ST2 & 0.06993 & 0.93506 & 2 \\
5 & FEO & 0.31750 & 1.25256 & 5 \\
6 & ST3 & 0.09445 & 1.34701 & 3 \\
7 & PUU & 0.5100 & 1.85701 & 9 \\
8 & ST3 & 0.09445 & 1.95146 & 3 \\
9 & FEO & 0.31750 & 2.26896 & 5 \\
10 & ST2 & 0.06993 & 2.33889 & 2 \\
11 & VOID & 0.59700 & 2.93589 & 3 \\
\hline
\end{tabular}

(a) Composition specified in Table A-6. 
TABLE A-6

COMPOSITION SFECIFICATIONS FOR REGIONS OF DTFX MODEL OF CORE ZONE 3 PLATE CELL

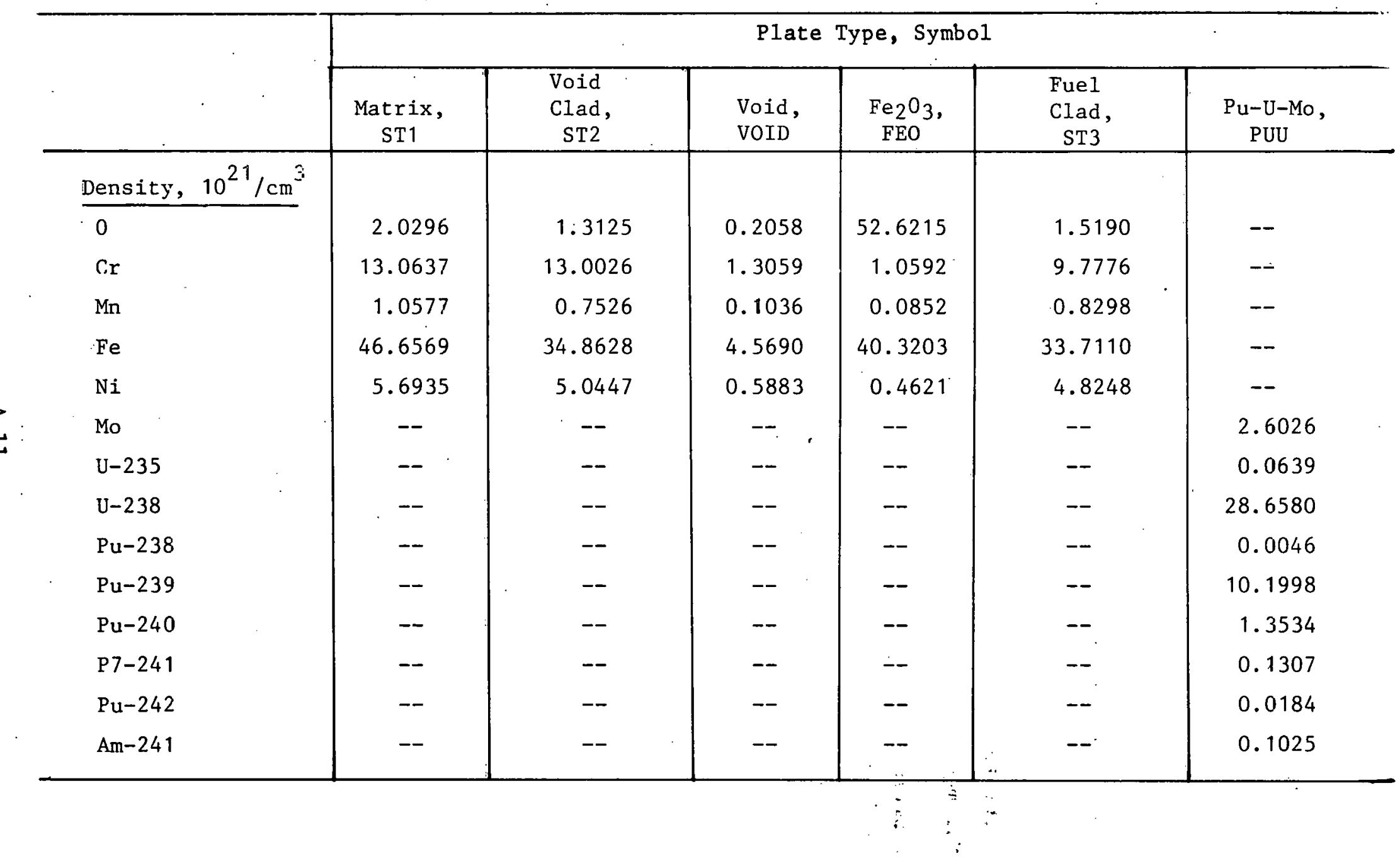


TABLE A-7

SPECIFICATIONS OF CYLINDRICAL CELL MODEL FOR DTFX CALCULATIONS OF HETEROGENEITY FACTORS FOR CORE PIN ZONE

\begin{tabular}{|c|c|c|c|}
\hline & \multicolumn{3}{|c|}{ Region No. } \\
\hline & 1 & 2 & 3 \\
\hline Material & $\mathrm{PuO}_{2}-\mathrm{UO}_{2}$ & Clad & $\begin{array}{l}\text { Coolant and } \\
\text { smeared structure }\end{array}$ \\
\hline Outer radius, $\mathrm{cm}$ & 0.42900 & 0.52070 & 0.77922 \\
\hline No. mesh intervals & 12 & 4 & 9 \\
\hline Composition, $10^{21} \mathrm{a} / \mathrm{cm}^{2}$ & & & \\
\hline 0 & 45.2759 & 2.1430 & 0.2064 \\
\hline $\mathrm{Cr}$ & -- & 16.8404 & 1.9361 \\
\hline Mn & -- & 1.2567 & 0.1103 \\
\hline $\mathrm{Fe}$ & -- & 58.6579 & 6.8888 \\
\hline $\mathrm{Ni}$ & - & 8.6291 & 0.6348 \\
\hline $\mathrm{U}-235$ & 0.0435 & -- & $\because$ \\
\hline $\mathrm{U}-238$ & 19.1979 & -- & -- \\
\hline $\mathrm{Pu}-238$ & 0.0016 & - & -- \\
\hline $\mathrm{Pu}-239$ & 2.9152 & -- & -- \\
\hline $\mathrm{Pu}-240$ & 0.3883 & -- & -- \\
\hline $\mathrm{Pu}-241$ & 0.0475 & -- & -- \\
\hline $\mathrm{Pu}-242$ & 0.0066 & -- & -- \\
\hline$A m-241$ & 0.0373 & -- & -- \\
\hline
\end{tabular}


TABLE A-8

PHASE III CRITICAL EXPERIMENT CALCULATED RADIAL WORTH TRAVERSES FOR CORE MATERIAL SAMPLES

\begin{tabular}{|c|c|c|c|c|c|}
\hline \multirow[b]{2}{*}{ Point } & \multirow{2}{*}{$\begin{array}{l}\text { Radius } \\
\quad(\mathrm{cm})\end{array}$} & \multicolumn{4}{|c|}{ Normalized Worth $(\mathrm{Ih} / \mathrm{kg})$} \\
\hline & & $\mathrm{Pu}$ & Enriched U & Depleted U & SS \\
\hline 1 & 1.05 & 141.70 & 103.30 & -7.6300 & -4.6900 \\
\hline 2 & 3.16 & 141.40 & 103.10 & -7.6140 & -4.6790 \\
\hline 3 & 5.26 & 140.90 & 102.73 & -7.5830 & -4.6570 \\
\hline 4 & 7.36 & 140.20 & 102.17 & -7.5350 & -4.6250 \\
\hline 5 & 9.47 & 139.20 & 101.42 & -7.4730 & -4.5810 \\
\hline 6 & 11.57 & 137.90 & 100.48 & -7.3950 & -4.5270 \\
\hline 7 & 13.68 & 136.40 & 99.36 & -7.3020 & -4.4630 \\
\hline 8 & 15.78 & 134.70 & 98.07 & -7.1940 & -4.3890 \\
\hline 9 & 17.88 & 132.70 & 96.60 & -7.0710 & -4.3050 \\
\hline 10 & 19.99 & 130.50 & 94.96 & -6.9340 & -4.2110 \\
\hline 11 & 22.09 & 128.10 & 93.15 & -6.7840 & -4.1090 \\
\hline 12 & 24.19 & 125.50 & 91.18 & -6.6200 & -3.9970 \\
\hline 13 & 26.30 & 122.70 & 89.06 & -6.4430 & -3.8780 \\
\hline 14 & 28.34 & 119.70 & 86.84 & -6.2590 & -3.7540 \\
\hline 15 & 30.32 & 116.70 & 84.57 & -6.0690 & -3.6270 \\
\hline 16 & 32.30 & 113.60 & 82.17 & -5.8690 & -3.4940 \\
\hline 17 & 34.29 & 110.23 & 79.65 & -5.6600 & -3.3560 \\
\hline 18 & 36.28 & 106.77 & 77.01 & -5.4400 & -3.2120 \\
\hline 19 & 38.25 & 103.16 & 74.26 & -5.2110 & -3.0640 \\
\hline 20 & 40.23 & 99.42 & 71.41 & -4.9730 & -2.9110 \\
\hline 21 & 42.21 & 95.56 & 68.45 & -4.7260 & -2.7550 \\
\hline 22 & 44.19 & 91.59 & 65.40 & -4.4710 & -2.5970 \\
\hline 23 & 46.18 & 87.53 & 62.28 & -4.1850 & -2.4030 \\
\hline 24 & 48.22 & 83.16 & 58.86 & -3.9340 & -2.1580 \\
\hline 25 & 50.31 & 78.45 & 55.37 & -3.5800 & -1.8670 \\
\hline 26 & 52.41 & 73.61 & 51.87 & -3.2090 & -1.5410 \\
\hline 27 & 54.51 & 68.65 & 48.35 & -2.8440 & -1.2130 \\
\hline 28 & 56.61 & 63.62 & 44.84 & -2.4850 & -0.8860 \\
\hline 29 & 58.71 & 58.56 & 41.35 & -2.1340 & -0.5640 \\
\hline 30 & 60.81 & 53.53 & 37.93 & -1.7960 & -0.2519 \\
\hline 31 & 62.90 & 48.61 & 34.62 & -1.4280 & 0.1208 \\
\hline 32 & 64.78 & 44.06 & 31.50 & -0.9397 & 0.4450 \\
\hline 33 & 66.44 & 40.17 & 29.04 & -0.6215 & 0.8460 \\
\hline 34 & 68.10 & 36.45 & 26.79 & -0.2908 & 1.2370 \\
\hline 35 & 69.76 & 33.24 & 25.07 & 0.3156 & 2.1320 \\
\hline 36 & 71.56 & 30.00 & 23.72 & 0.4222 & 2.1660 \\
\hline 37 & 73.49 & 26.89 & 21.10 & 0.0823 & 1.3700 \\
\hline 38 & 75.43 & 23.62 & 18.95 & 0.0542 & 1.1510 \\
\hline 39 & 77.36 & 20.65 & 16.87 & 0.0358 & 0.9530 \\
\hline 40 & 79.29 & 17.99 & 14.92 & 0.0230 & 0.7810 \\
\hline 41 & 81.23 & 15.62 & 13.12 & 0.0140 & 0.6330 \\
\hline 42 & 83.16 & 13.52 & 11.49 & 0.0073 & 0.5080 \\
\hline 43 & 85.09 & 11.68 & 10.03 & 0.0020 & 0.4040 \\
\hline 44 & 87.03 & 10.08 & 8.732 & 0.0023 & 0.3190 \\
\hline 45 & 88.96 & 8.711 & 7.594 & 0.0058 & 0.2486 \\
\hline 46 & 90.89 & 7.539 & 6.609 & -0.0089 & 0.1920 \\
\hline 47 & 92.83 & 6.550 & 5.763 & -0.0116 & 0.1466 \\
\hline 48 & 94.76 & 5.722 & 5.046 & -0.0141 & 0.1103 \\
\hline 49 & 96.69 & 5.038 & 4.445 & -0.0162 & 0.0806 \\
\hline 50 & 98.63 & 4.487 & $\ldots \quad 3.954$ & -0.0106 & 0.0721 \\
\hline
\end{tabular}


TABLE A-9

PHASE III CRITICAL EXPERIMENT CALCULATED RADIAL WORTH TRAVERSES FOR POISON, MODERATOR; AND SOURCE SAMPLES

\begin{tabular}{|c|c|c|c|c|c|}
\hline \multirow[b]{2}{*}{ Point } & \multirow[b]{2}{*}{$\begin{array}{c}\text { Radius } \\
\text { (cm) }\end{array}$} & \multicolumn{4}{|c|}{ Normalized Worth ( $\mathrm{Ih} / \mathrm{kg})$} \\
\hline & & B-10 & $\mathrm{Ch}_{2}$ Foam & $\mathrm{Cf}-252$ & $\mathrm{Li}-6$ \\
\hline$i$ & 1.05 & -1928.00 & -222.44 & 1000.40 & -1502.00 \\
\hline 2 & 3.16 & -1924.30 & -222.10 & 999.50 & -1499.30 \\
\hline 3 & 5.26 & -1917.10 & -221.42 & 997.70 & -1493.90 \\
\hline 4 & 7.36 & -1906.40 & -220.39 & 995.10 & -1485.80 \\
\hline 5 & 9.47 & -1892.10 & -219.01 & 971.50 & -1475.10 \\
\hline 6 & 11.57 & -1874.30 & -217.29 & 987.10 & -14.61 .80 \\
\hline 7 & 13.68 & -1853.10 & -215.21 & 981.80 & -1445.90 \\
\hline 8 & 15.78 & -1828.40 & -212.77 & 975.70 & -1427.40 \\
\hline 9 & 17.88 & -1800.50 & -209.96 & 968.60 & -1406.50 \\
\hline 10 & 19.99 & -1769.40 & -205.75 & 960.80 & -138.3 .30 \\
\hline 11 & 22.09 & -1735.20 & -203.13 & 952.00 & -1357.80 \\
\hline 12 & 24.19 & -1598.00 & -199.06 & 942.50 & -1330.00 \\
\hline 13 & 26.30 & -1657.70 & -194.51 & 932.10 & -1300.00 \\
\hline 14 & 28.34 & -1616.20 & -189.56 & 921.20 & -1268.90 \\
\hline 15 & 30.32 & -1573.40 & -184.23 & 909.80 & $-1<37.10$ \\
\hline 16 & 32.30 & -1528.30 & -178.29 & 897.80 & -1203.50 \\
\hline 17 & 34.29 & -1481.10 & -171.66 & 885.10 & -1168.40 \\
\hline 18 & 36.28 & -1431.80 & -164.23 & 871.60 & -1131.80 \\
\hline 19 & 38.25 & -1380.50 & -155.88 & 857.40 & -1093.80 \\
\hline 20 & 40.23 & -1327.50 & -146.45 & 842.60 & -1054.40 \\
\hline 21 & 42.21 & -1272.60 & -135.78 & 827.00 & -1013.80 \\
\hline 22 & 44.19 & -1216.10 & -123.66 & 810.80 & -.971 .80 \\
\hline 23 & 46.18 & -1157.60 & -109.43 & 793.80 & -928.50 \\
\hline 24 & 48.22 & -1094.10 & -90.065 & 775.20 & -882.10 \\
\hline 25 & 50.31 & -1027.80 & -74.333 & 753.60 & -831.10 \\
\hline 26 & 52.41 & -960.97 & $-61: 526$ & 730.20 & -774.10 \\
\hline 27 & 54.51 & -892.40 & -51.032 & 704.90 & -716.00 \\
\hline 28 & 56.61 & -824.30 & -42.232 & 677.90 & -660.60 \\
\hline 29 & 58.71 & -756.60 & -34.785 & 649.30 & -601.80 \\
\hline 30 & 60.81 & -689.90 & -28.549 & 619.40 & -543.70 \\
\hline 31 & 62.90 & -624.30 & -22.705 & 588.10 & -488.80 \\
\hline 32 & 64.78 & -552.80 & -23.801 & 558.30 & -438.80 \\
\hline 33 & $66 . .44$ & -499.10 & -32.739 & 529.30 & -393.10 \\
\hline 34 & 68.10 & -446.60 & -46.216 & 498.70 & -347.70 \\
\hline 35 & 69.76 & -391.10 & -60.116 & 166.60 & -300.00 \\
\hline 36 & 71.56 & -335.30 & -91.529 & 430.90 & $-25 j .20$ \\
\hline 37 & 73.49 & -284.60 & -109.46 & 395.00 & -212.50 \\
\hline 38 & 75.43 & -236.50 & -112.33 & 361.40 & -174.90 \\
\hline 39 & 77.36 & -194.90 & -109.08 & 330.20 & -143.00 \\
\hline 40 & 79.29 & -159.60 & -101.91 & 301.10 & -116.20 \\
\hline 41 & 81.23 & -130.10 & -92.535 & 274.10 & -94.08 \\
\hline 42 & 83.16 & -105.70 & -82.165 & 249.30 & -75.90 \\
\hline 43 & 85.09 & -85.68 & -71.658 & 226.30 & -61.08 \\
\hline 44 & 87.03 & -69.43 & -61.572 & 205.30 & -49.10 \\
\hline 45 & 88.96 & -56.34 & -52.246 & 185.90 & -39.36 \\
\hline 46 & 90.89 & -45.87 & -43.854 & 168.20 & -31.78 \\
\hline 47 & 92.83 & -37.56 & -30.459 & 152.00 & -25.38 \\
\hline 48 & 94.76 & -31.04 & -30.044 & 137.20 & -20.86 \\
\hline 49 & 96.69 & -25.98 & -24.545 & 123.70 & -17.10 \\
\hline 50 & 98.63 & -22.04 & -19.707 & 111.40 & -14.10 \\
\hline
\end{tabular}


TABLE A-10

PHASE III CRITICAL EXPERIMENT CALCULATED RADIAL REACTION RATE PROFILES

\begin{tabular}{|c|c|c|c|c|c|c|}
\hline \multirow[b]{2}{*}{ Point } & \multirow[b]{2}{*}{$\begin{array}{l}\text { Radius } \\
\quad(\mathrm{cm})\end{array}$} & \multicolumn{5}{|c|}{ Normalized Reaction Rates } \\
\hline & & $\begin{array}{c}\text { U-235 } \\
\text { Fission }\end{array}$ & $\begin{array}{l}\text { Pu-239 } \\
\text { Fission }\end{array}$ & $\begin{array}{c}\text { U-238 } \\
\text { Fission }\end{array}$ & $\begin{array}{c}\mathrm{U}-238 \\
\text { Capture }\end{array}$ & $\begin{array}{c}\text { Li-6 } \\
\text { Capture }\end{array}$ \\
\hline 1 & 1.38 & 999.80 & 999.80 & 999.30 & 959.80 & 999.80 \\
\hline 2 & 4.14 & 998.20 & 998.20 & 998.40 & 999.10 & 998.10 \\
\hline 3 & 6.91 & 995.00 & 995.20 & 995.50 & 994.80 & 994.80 \\
\hline 4 & 9.67 & 990.10 & 990.50 & 991.30 & 939.90 & 989.80 \\
\hline 5 & 12.43 & 783.70 & 984.30 & 985.70 & 983.20 & 983.20 \\
\hline 6 & 15.19 & 975.60 & 976.60 & 978.70 & 974.90 & 924.90 \\
\hline 7 & 17.95 & 965.90 & 967.40 & 970.50 & 964.90 & 954.90 \\
\hline 8 & 20.72 & 954.60 & 956.50 & 961.00 & 953.20 & 953.30 \\
\hline 9 & 23.48 & 741.60 & 944.20 & 950.20 & 939.80 & 939.90 \\
\hline 10) & 26.24 & 926.90 & 930.20 & 938.50 & 924.60 & 924.80 \\
\hline 19 & 29.00 & 910.60 & 714.70 & 925.80 & 907.70 & 907.90 \\
\hline 12 & 31.76 & 892.50 & 897.70 & 912.20 & 886.90 & 839.20 \\
\hline 13 & 34.53 & 872.60 & 879.00 & 898.10 & 850.20 & 868.60 \\
\hline 14 & 37.29 & 851.00 & 858.80 & 883.70 & $84 \% .70$ & 840.10 \\
\hline 15 & 40.05 & 827.40 & 837.00 & 869.40 & 821.00 & 321.50 \\
\hline 16 & 42.81 & 801.90 & 313.40 & 855.70 & 794.30 & 794.80 \\
\hline 17 & 45.58 & 774.20 & 788.20 & 843.30 & 765.20 & 765.50 \\
\hline 18 & 48.34 & 744.60 & 757.80 & 842.20 & 735.60 & 726.90 \\
\hline 19 & 51.10 & 713.30 & 728.00 & 821.40 & 703.70 & 694.30 \\
\hline 20 & 53.86 & 681.30 & 695.90 & 791.90 & 671.70 & 660.80 \\
\hline 21 & 56.63 & 548.30 & 661.80 & 754.70 & 639.50 & 626.30 \\
\hline 22 & 59.39 & 614.70 & 625.90 & 710.60 & 607.20 & 590.90 \\
\hline 23 & 62.15 & 580.80 & 588.50 & 659.80 & 575.10 & 355.10 \\
\hline 24 & 64.91 & 538.90 & 543.80 & 608.30 & 537.70 & 513.60 \\
\hline 25 & $67.6 ?$ & 506.20 & 502.10 & 515.60 & 510.50 & 480.80 \\
\hline 26 & 70.44 & 501.50 & 491.30 & 364.90 & 491.40 & 453.90 \\
\hline 27 & 73.20 & 471.80 & 454.10 & 280.70 & 464.70 & 121.10 \\
\hline 28 & 75.96 & 440.70 & 417.90 & 216.00 & 435.30 & 388.00 \\
\hline 29 & 78.72 & 409.60 & 383.50 & 166.40 & 404.70 & 355.00 \\
\hline 30 & 81.48 & 379.80 & 351.80 & 128.30 & 374.30 & 323.50 \\
\hline 31 & 84.25 & 352.30 & 323.40 & 99.05 & 345.10 & 294.60 \\
\hline 32 & 87.01 & 328.00 & 299.20 & 76.63 & 318.10 & 268.90 \\
\hline 33 & $89.7 ?$ & $30 ? .90$ & 279.70 & 59.43 & 293.90 & 247.10 \\
\hline 34 & 92.53 & 293.00 & 265.90 & 46.23 & 273.50 & 229.90 \\
\hline 35 & 95.30 & 284.60 & 258.30 & 36.07 & 257.60 & 218.10 \\
\hline 36 & 98.06 & 292.40 & 269.70 & 24.52 & 246.30 & 216.60 \\
\hline 37 & 100.82 & 278.60 & 260.50 & 15.15 & 220.90 & 201.00 \\
\hline 38 & 103.58 & 244.00 & 230.00 & 9.35 & 186.30 & 173.20 \\
\hline 39 & 106.35 & 195.30 & 185.20 & 5.72 & 145.00 & 137.50 \\
\hline 40 & 109.11 & 137.60 & 130.80 & 3.42 & 101.60 & 96.50 \\
\hline 41 & 111.87 & 74.10 & 70.60 & 1.89 & 55.11 & 52.40 \\
\hline
\end{tabular}


TABLE A-11

PHASE III CRITICAL EXPERIMENT CALCULATED AXIAL REACTION RATE PROFILES

\begin{tabular}{|c|c|c|c|c|c|c|}
\hline \multirow[b]{2}{*}{ Point } & \multirow[b]{2}{*}{$\begin{array}{c}\text { Axial } \\
\text { Position } \\
\text { (cm) }\end{array}$} & \multicolumn{5}{|c|}{ Normalized Reaction Rates } \\
\hline & & $\begin{array}{c}\text { U-235 } \\
\text { Fission }\end{array}$ & $\begin{array}{r}\text { Pu-239 } \\
\text { Fission }\end{array}$ & $\begin{array}{c}\mathrm{U}-238 \\
\text { Fission }\end{array}$ & $\begin{array}{c}\text { U-238 } \\
\text { Capture }\end{array}$ & $\begin{array}{l}\text { Pin Zone } \\
\text { Pu-239 } \\
\text { Fission }\end{array}$ \\
\hline 1 & 1.02 & 999.80 & 999.80 & 999.80 & 979.80 & 999.80 \\
\hline 2 & 3.05 & 998.3 .0 & 998.30 & 998.30 & 998.30 & 998.30 \\
\hline 3 & 5.09 & 995.40 & 995.30 & 995.30 & 995.40 & 995.30 \\
\hline 4 & 7.12 & 990.90 & 990.80 & 990.70 & 994.00 & 990.80 \\
\hline 5 & 9.16 & 985.10 & 984.90 & 984.80 & 985.20 & 984.80 \\
\hline 6 & 11.19 & 977.80 & $97 \% .50$ & 977.30 & 977.90 & 977.40 \\
\hline 7 & 13.23 & 969.00 & 968.60 & 968.30 & 968.50 & 968.50 \\
\hline 8 & 15.26 & 958.90 & 958.30 & 957.80 & 959.20 & 958.10 \\
\hline 9 & 17.29 & 947.30 & 946.60 & 945.90 & 947.80 & 946.40 \\
\hline 10 & 19.33 & 934.50 & 933.50 & 9.32 .50 & 935.00 & 933.20 \\
\hline 11 & 21.36 & 920.30 & 919.10 & 917.80 & 920.90 & 918.50 \\
\hline 12 & 23.40 & 904.80 & 903.30 & 901.50 & 905.60 & 902.80 \\
\hline 13 & 25.43 & 8.88 .00 & 886.20 & 883.90 & 889.10 & 885.70 \\
\hline 14 & 27.47 & 870.10 & 867.90 & 864.90 & 871.40 & 867.30 \\
\hline 15 & 29.50 & 851.10 & 848.40 & 844.50 & 852.70 & 847.70 \\
\hline 16 & 31.54 & 830.90 & 827.60 & 822.70 & 832.90 & 826.90 \\
\hline 17 & 33.57 & 809.70 & 805.80 & 799.50 & 812.10 & 805.00 \\
\hline 18 & 35.61 & 787.60 & 783.00 & 774.90 & 790.40 & 782.00 \\
\hline 19 & 37.64 & 764.60 & 759.10 & 748.80 & 768.00 & 758.10 \\
\hline 20 & 39.68 & 740.80 & 734.30 & 721.30 & 744.80 & 733.30 \\
\hline 21 & 41.71 & 716.30 & 708.60 & 692.40 & 721.00 & 707.60 \\
\hline 22 & 43.75 & 691.20 & 682.20 & 661.80 & 696.80 & 681.30 \\
\hline 23 & 45.78 & 665.70 & 655.10 & 629.60 & 672.20 & 6.54 .30 \\
\hline 24 & 47.81 & 639.80 & 627.40 & 595.60 & 647.40 & 626.90 \\
\hline 25 & 49.85 & 613.80 & 599.30 & 559.60 & 622.50 & 599.10 \\
\hline 26 & 51.88 & 587.9 .0 & 570.80 & 521.50 & 597.80 & 571.20 \\
\hline 27 & 53.92 & 562.10 & 542.20 & 481.00 & 573.50 & 543.50 \\
\hline 28 & 55.95 & 536.90 & 513.60 & 437.60 & 549.80 & 520.40 \\
\hline 29 & 57.99 & 512.50 & 485.30 & 391.10 & 527.00 & 489.60 \\
\hline 30 & 60.02 & 489.30 & 457.40 & 340.80 & 505.40 & 464.40 \\
\hline 31 & 62.06 & 485.60 & 464.20 & 271.90 & 485.40 & 441.00 \\
\hline 32 & 64.09 & 464.50 & 440.50 & 230.30 & 465.00 & 417.50 \\
\hline 33 & 66.12 & 443.30 & 417.30 & 195.20 & 414.20 & \\
\hline 34 & 68.15 & 422.30 & 394.90 & 165.50 & 423.20 & \\
\hline 35 & 70.18 & 401.80 & 373.50 & 140.50 & 402.30 & \\
\hline 36 & 72.22 & 382.00 & 353.10 & 119.20 & 381.90 & \\
\hline 37 & 74.25 & 363.10 & 334.00 & 101.36 & 362.00 & \\
\hline 38 & 76.28 & 345.30 & 3.16 .40 & 86.20 & 343.00 & \\
\hline 39 & 78.31 & 328.80 & 300.30 & 73.38 & 324.90 & \\
\hline 40 & 80.34 & 313.90 & 285.90 & 62.52 & 308.00 & \\
\hline 41 & 82.38 & 300.60 & 273.40 & 53.33 & 292.30 & \\
\hline 42 & 84.41 & 289.40 & 263.00 & 45.53 & 278.10 & \\
\hline 43 & 86.44 & 280.30 & 254.90 & 38.92 & 265.50 & \\
\hline 44 & 88.47 & 273.70 & 249.30 & 33.31 & 254.70 & \\
\hline 45 & 90.50 & 269.90 & 246.70 & 28.53 & 245.90 & \\
\hline 46 & 93.07 & 277.00 & 257.40 & 19.85 & 235.60 & \\
\hline 47 & 96.17 & 257.00 & 242.70 & 11.90 & 205.40 & \\
\hline 48 & 99.27 & 213.20 & 203.40 & 7.10 & 164.40 & \\
\hline 49 & 102.36 & 154.10 & 147.80 & 5.06 & 116.40 & \\
\hline 50 & 105.46 & 85.38 & 82.10 & 2.56 & 64.59 & \\
\hline 51 & 108.87 & 45.02 & 43.38 & 1.58 & 34.89 & \\
\hline 52 & 112.60 & 38.43 & 37.03 & 1.47 & 30.04 & \\
\hline 53 & 116.34 & 32.11 & 30.96 & 1.36 & 25.39 & \\
\hline
\end{tabular}

